\section{NEW M A N S T U D I S J O U R A L}

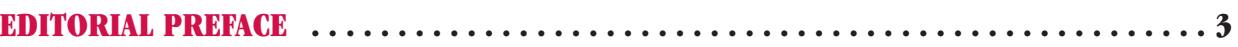

\section{ARTICLES}

Newman's First Two Notes on Development and Patristic Millenarianism ........ 4 Steven D. Aguzzi

Apologia pro Vita Stulti: Newman's Defense of the "Superstitious Masses"

.20

Jonathan Martin Ciraulo

Reading the Bible and the Doctrinal Question in

Arians of the Fourth Century ......................................

Kota Kanno

\section{NEWMAN LECTURE SERIES}

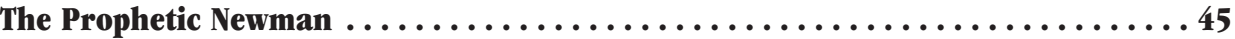

Brad S. Gregory

\section{BOOK REVIEW}

Peter C. Wilcox, S.T.D.:Jobn Henry Newman: Spiritual Director (1845-1890) .60 Reviewed by Kevin Mongrain

\section{NINS UPDATI}

What's New at NINS

Mary Jo Dorsey

BIBLIOGRAPHY ..........................................6 64

NEWMAN CHRONOLOGY

\section{NEWMAN STUDIES JOURNAL}

(3.):

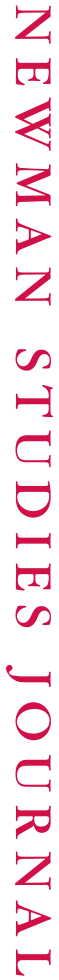

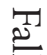

$\stackrel{\text { N }}{\stackrel{1}{A}}$

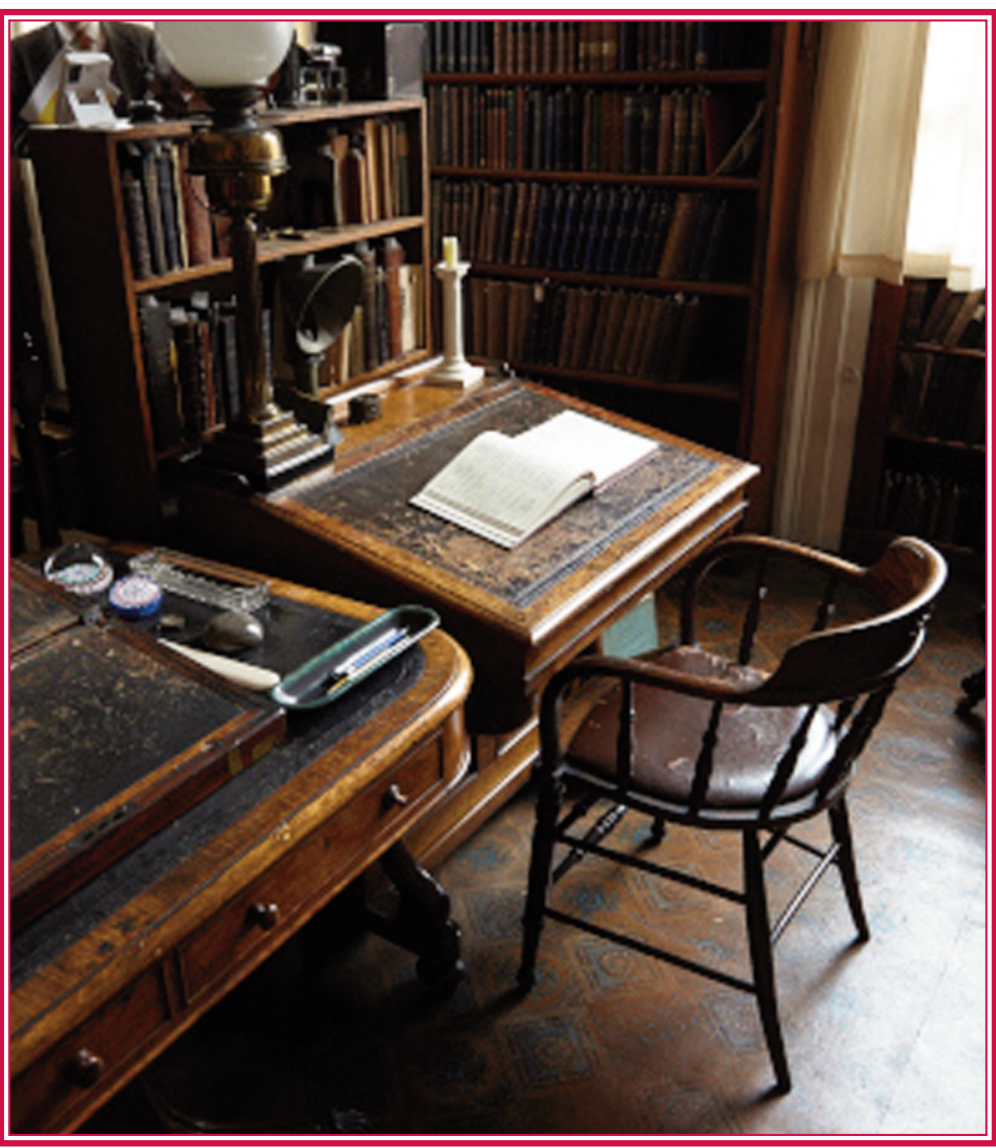

"God is everywhere as absolutely and entirely as if He were nowhere else" and it seems to be essential to the existence of every creature, rational and irrational, good and evil, in beaven and bell, that in some sense or other He should be present with it and be its life. Thus we are told concerning mankind, that 'in Him we live, and move, and have our being' And He who lives in all creatures on earth in order to their mortal life, lives in Christians in a more divine way in order to their life immortal; and as we do not know bow the creation exists and lives in Him as a Creator, and use words about it beyond our comprebension, so much more... are we ignorant of the mode or nature of that life of God in the soul, which is the wellspring of the Christian's sanctity, and the seed of everlasting happiness." 


\section{NEW MAN S T UDIES J O UR N L}

The Newman Studies Journal (NSI) is an English language journal that publishes articles relating to the Blessed John Henry Cardinal Newman in the areas of education, history, literature philosophy, spirituality, and theology. NSJ is published by The National Institute for Newman Studies® (NINS), a nonprofit organization that provides resources for scholars dedicated to promoting the study of Newman's life, influence, and work. In addition to publishing NSI, the Institute maintains the Newman Research Library in Pittsburgh, Pennsylvania, and sponsors the Newman Scholarship Program. NSS is indexed in the Catholic Periodical and Literature Index (CPLI), a product of the American Theological Library Association, and in EBSCO Publishing's Religion and Philosophy research database (EBSCOHost).

\section{General Editor}

Kevin Mongrain, Duquesne University, The National Institute for Newman Studies

\section{Editors}

Gerard H. McCarren, Immaculate Conception Seminary, Seton Hall University

M. Katherine Tillman, University of Notre Dame

\section{Associate Editors}

Drew Morgan, C.O., The Pittsburgh Oratory

Catharine M. Ryan, The National Institute for Newman Studies

\section{Managing Editor}

Celeste Barker Bright, The National Institute for Newman Studies

\section{Editorial Consultants}

Frederick Aquino, Abilene Christian University

Jerome Bertram, C.O., The Oxford Oratory

Duane Bruce, Saint Anselm College

Edward J. Enright, 0.S.A., Merrimack College

Marvin R. O'Connell, University of Notre Dame

Bernadette Waterman Ward, University of Dallas

\section{NSJ Board of Directors}

Catharine M. Ryan, Chair

Gerard H. McCarren

Drew Morgan, C.O.

Marvin R. O'Connell

M. Katherine Tillman

\section{Cover Art}

John Henry Newman's private study at the Birmingham Oratory in England. Photo courtesy of the

National Institute for Newman Studies.
Article Submissions:

Manuscripts should be submitted electronically in Microsoft Word as an e-mail attachment to cbright@ninsdu.org For complete guidelines, revised March 2014, e-mail cbright@ninsdu.org.

In brief: NSJ follows the Chicago Mamual of Style, 16th edition (2010) and uses as its spelling guide Webster's Third New International Dictionary (2002) or bttp://www.merriam-webster.com/. However, in direct quotations from nonAmerican Anglophone sources, please retain the original rules of spelling.

Manuscripts for articles should not exceed 7500 words (approximately 25 double-spaced pages) including biography, abstract, and footnotes.

NSJ requests that authors:

- Double space all copy including titles, block quotations, footnotes, biography, and summary.

- Number all pages at top right.

- Cite all sources, ensure that citations occur in footnotes, and follow the Chicago Manual of Style.

- Use gender-inclusive language and American spelling, except in quotations from a non-American Anglophone source.

- Italicize titles of books, journals, and foreign words, but do not italicize foreign terms commonly used in English, e.g. ibid., de iure, prima facie.

- Use three double-spaced dots to replace omitted parts of citations; at the end of a sentence, this ellipsis is followed by a period.

- Please do not use bold type, footnotes, or headers/footers.

- Please do not use right-margin justification within the text, block quotations, or the footnotes.

- Please provide a one-paragraph summary of the article (of approximately six lines; see a current issue of NSJ for examples.)

- Please provide a brief autobiographical description (of approximately three lines; see a current issue for examples.)

Although not required, we invite authors to use and cite the editions of Newman's work available at www.newmanreader:org. A reference to this website should be included in a footnote the first time a work is cited.

\section{Subscriptions:}

NSJ is now available online as well as in print. All issues, from volume 1 (2004) to the present, are included with each electronic subscription. Annual individual subscriptions are priced as follows: Print- $\$ 30.00$; Online (Single user electronic subscription. Annual individual subscriptions are priced as follows: Print--\$30.00; Online (Single user
license)--\$48.00; Print and Online (Single user license)--\$75.00. Annual institutional subscriptions are: Print-- $\$ 58.00$ license)--\$48.00; Print and Online (Single user license)--\$75.00. Annual institutional subscriptions are: Print--\$8.01
Online (5 simultaneous access license)--\$174.00; Print and Online ( 5 simultaneous access license)--\$209.00. All Online (5 simultaneous access license)--\$174.00; Print and Online ( 5 simultaneous access license) - \$209.00. All
issues, from volume 1 (2004) to the present, are included with each electronic subscription. Single print issues are issues, from volume 1 (2004) to the present, are included with each electronic subscription. Single print issues are
$\$ 29$ for institutions and \$15 for individuals. All subscription requests, claims, and renewals should be sent to the \$29 for institutions and \$15 for individuals. All subscription requests, claims, and renewals should be sent to the Newman Studies Journal, c/o Philosophy Documentation Center, P.O. Box 7147, Charlottesville, VA 22906-7147,
Payment may also be made by credit card (Visa, MasterCard, Discover) online at $b t t p: / / s e c u r e . p d c n e t . o r g / p d c /$ bvdb.nsffjournal?openformEjournal=pdc_ns;\#asubscribe; by fax to 434-220-3301; or by phone at 434-220-3300. Subscribers in the US and Canada may call toll free at 800-444-2419. For more subscription information contact Philosophy Documentation Center at 800-444-2419; 434-220-3300, or by e-mail at order@pdcnet.org.

Newman Studies Journal (ISSN 1547-9080, print; ISSN 2153-6945, online) is owned and published in the spring and fall by The National Institute for Newman Studies®, a non-profit organization, 211 N. Dithridge St., Pittsburgh, PA, 15213. Send written requests for reproducing parts of the print or electronic version of NS/ to Kevin Mongrain, Newman Studies Journal, 211 N. Dithridge St., Pittsburgh, PA, 15213; phone 412-681-4375; fax 412-681-4376; e-mail kmongrain@ninsdu.org.

For more information on the National Institute for Newman Studies® or the Newman Studies Journal, please visit: www.newmanstudiesinstitute.org.

Copyright @ National Institute for Newman Studies®, 2014 


\section{A LETTER TO OUR READERS}

Dear Readers,

We are pleased that the Fall issue of $N S J$ has appeared in a more timely manner than the Spring issue, and that we have surmounted the difficulties we previously faced. We are beginning a partnership with a new printing company, LionWorks Printing and Graphics, and we expect that this decision will make a significant difference in the efficient production of the journal.

We are also expanding the scope of $N S J$ content: beginning with this issue, we will include a section for our new published lecture series, featuring the annual Newman Legacy and Newman Memorial lectures hosted by Duquesne University and sponsored by NINS.The published lectures will differ from traditional articles in that they will allow the speakers/authors more latitude than would conventional scholarly research essays. Readers unable to attend the lectures will now be able to read them in much the way they were originally delivered, as their published form will allow for the stylistic and rhetorical features that characterize oral presentations.

The first lecture in the series is the annual Spring Newman Legacy lecture, which was delivered by Brad S. Gregory at Duquesne University on April 3, 2014. Readers interested in learning more about his research are encouraged to read his two books, Salvation at Stake: Christian Martyrdom in Early Modern Europe (1999) and The Unintended Reformation: How a Religious Revolution Secularized Society (2012).

We hope you will enjoy our new series.

Sincerely,

Celeste Barker Bright

Managing Editor, NSJ

Kevin Mongrain

General Editor, NSJ

Executive Director, NINS 


\title{
NEWMANS FIRST TWO NOTES ON DEVELOPMENT AND PATRISTIC MILLENARIANISM
}

\author{
STEVEN D. AGUZZI
}

\begin{abstract}
In recent years, critical discourse concerning the millenarian eschatology of the early Patristic era of Christianity has called into question the common notion that millenarian concepts have been utterly rejected as beretical by the Roman Catholic Church. No Ecumenical Council has ever rejected millenarian eschatology, and papal and juridical statements on the issue have been taken out of context. This essay brings forward, as testing agents, John Henry Newman's first two notes in Development in order to determine whether Patristic millenarianism, along with a more recently explored version called Eucharistic millenarianism, is a valid example of doctrinal development of an earlier type. Eucharistic millenarianism borrows many aspects from a primitive apostolic source and has been embraced by the Catholic hierarchy, raising the question of how millenarian aspects might legitimately inform contemporary theology. Newman's theory of the development of doctrine, particularly as seen in his first two notes, is a valuable tool for reevaluating latent concepts that have been unfairly viewed as marginal or even beretical in mainline theological discourse.
\end{abstract}

T his essay examines the first two of John Henry Newman's "Notes" as defined in An Essay on the Development of Christian Doctrine for the purpose of discerning whether a set of beliefs is a valid development of doctrine or a corruption of its original, latent meaning. It does this in application to a unique and often glossedover eschatological system: the millenarianism of first- and second-century Christianity. "Patristic millenarianism" is a curious case because it was uniformly and normatively held by theologians of good repute, was passed down as the deposit of eschatological belief, and was never fully replaced by any other system in terms of popular piety; its incarnations still carry great weight in the Church to this day, despite the adoption of Augustine's amillenial model in the fourth century. Although the Church in the modern era has formally rejected certain strands of millenarian belief, contrary to popular theological misconceptions, the overall system of millenarian eschatology-including Joachim of Fiore's version-has never been censured by the Magisterium through an ecumenical council, papal decree, or binding pronouncement. By applying Newman's "Notes" to millenarianism, and drawing a connection between its latent, original, Patristic forms and a new interpretation labeled "Eucharistic Millenarianism" - a system the Magisterium is open to considering-we will endeavor to shed light on the ambiguities of modern Catholic eschatological belief and highlight ways in which the tension between amillenial and millenarian views in Catholicism may point to a doctrinal development that is as yet unresolved.

Steven D. Aguzzi, Ph.D., is an ordained minister in the Presbyterian tradition and serves as an adjunct instructor at the Theology Department of Duquesne University in Pittsburgh, PA. 


\section{A BRIEF REVIEW OF PATRISTIC MILLENARIANISM AND THE VINCENTIAN CANON}

The revival of eschatological studies in the field of systematic theology is well known in contemporary scholarship, especially in light of recent studies that explore the most primitive views of the "Last Days," focusing on the early Apostolic Era. ${ }^{1}$ What is perhaps most surprising is that the normative eschatological view of the early Church, at least for the first 250 years, was millenarian in form, an eschatology of which the Church is now deeply skeptical. ${ }^{2}$ Despite the modern hierarchy's resistance to these primitive forms of eschatology, the Church as a whole has been reluctant to make definitive pronouncements on the subject, and there is no evidence of a formal papal or conciliar condemnation of millenarian belief. ${ }^{3}$ Millenarianismalso called chiliasm from the Greek root-is the concept that the twentieth chapter of John's Apocalypse refers to a literal period of time (usually, but not uniformly, considered to be one thousand years) within history, during which Jesus Christ will return to earth and reign with the martyrs prior to the final consummation, final judgment, and general resurrection. ${ }^{4}$

The millenarian view was the central one among the early Fathers and Doctors of the Church, and no alternative was codified until the time of Augustine (who himself was a millenarian in his early years). ${ }^{5}$ During the first 250 years of the Church's history, we find either millenarian eschatology or complete silence on the specific interpretation of Revelation 20 from those who accepted the work as canonical. ${ }^{6}$ Among the Latin and Greek apostolic and later Fathers through the early

\footnotetext{
${ }^{1}$ See Charles E. Hill, Regnum Caelorum: Patterns of Future Hope in Early Christianity, Oxford Early Christian Studies (Oxford and New York: Clarendon and Oxford University Press, 1992), and Dale C.Allison, Jesus of Nazareth: Millenarian Prophet (Minneapolis: Fortress, 1998).

${ }^{2}$ Likely in response to Hitler's use of millenarian rhetoric leading up to World War II, Pope Pius XII, in answering a question about the legitimacy of the early eschatology during an audience with bishops comprising the Sacred Congregation for the Doctrine of the Faith, said the following: "The system of mitigated Millenarianism cannot be taught safely." "Decree of the Holy Office," July 19/21, 1944, confirmed by Pope Pius XII, July 20, 1944 (DS3839). Hereafter cited: Pope Pius XII, "Decree of the Holy Office." The pope's view of millenarian eschatology was reiterated in the 1994 Catechism. See Catechism of the Catholic Church: With Modifications from the Editio Typica, 2nd ed. (New York: Doubleday, 1997), 194, Article 7, "From Thence He will come again to Judge the Living and the Dead," \$676. It appears that the Catechism's censure of millenarianism is aimed against Marxist forms of liberation theology. This is consistent with Pius XI's decree against politically realized messianic elements that promote a progressive view of social justice-a rhetoric he calls the "counterfeit of the redemption of the lowly." Rael Jean Isaac and Erich Isaac, The Coercive Utopians: Social Deception by America's Power Players (Chicago: Regnery Gateway, 1984), 148.

${ }^{3}$ The most thorough histories of the Ecumenical Councils omit any mention of millennialism whatsoever. See Brian E. Daley, S.J., The Hope of the Early Church: A Handbook of Patristic Eschatology (Cambridge: Cambridge University Press, 1991), 12; Francis X. Gumerlock,"Millennialism and the Early Church Councils: Was Chiliasm Condemned at Constantinople?" Fides et Historia 36, no. 2 (Summer/Fall 2004): 83-95, 85; Michael J. Svigel, "The Phantom Heresy: Did the Council of Ephesus (431) Condemn Chiliasm?" Trinity Journal 24 (2003): 105-12.

${ }^{4}$ For a fuller explanation of millenarian eschatology, see Daley, "Apocalypticism in Early Christian Theology," in Bernard McGinn, Stephen Stein and John J. Collins, The Continuum History of Apocalypticism, ed. Bernard J. McGinn (New York: Continuum, 2003), 221-53, 222.

${ }_{5}$ The early Augustine was a firm supporter of millenarian ideas. G. Folliet, "La typologie du sabbat chez saint Augustin: Son interprétation millénariste entre 388 et 400," Revue des études augustiniennes 2 (1956): 371-90. See also Ralph Mathisen, s.v. "Last Judgment," in Augustine through the Ages: An Encyclopedia, ed.Allan D. Fitzgerald (Grand Rapids, MI:Wm.B. Eerdmans, 1999), 478.

${ }^{6}$ Hill's Regnum Caelorum:Patterns of Millennial Thought in Early Christianity (Grand Rapids, MI:Wm. B. Eerdmans, 2001) attempts to establish a definitive amillennial view from the earliest of Apostolic times, but ultimately his work relies too heavily on an argument from silence. No primary sources from the first three centuries A.D. supporting an amillennial view of Revelation 20 exist. See Glenn R. Kreider, review of Regnum Caelorum: Patterns of Millennial Thought in Early Christianity by Charles E. Hill, Bibliotheca Sacra 160, no. 638 (April 2003): 253.
} 
fourth century, in addition to Papias ( d. 120), ${ }^{7}$ Justin (d. 165), ${ }^{8}$ and Irenaeus, ${ }^{9}$ we see millenarian testimony or influence in Clement of Rome (d. 99), ${ }^{10}$ Pseudo-Barnabas, ${ }^{11}$ Hegesippus ( 110-180), ${ }^{12}$ Julius Africanus (c. 160-c.240),${ }^{13}$ Pothinus the martyr from Lyons (d. 177) ${ }^{14}$ Melito of Sardis (d. 180),${ }^{15}$ the Egyptian bishop Nepos,${ }^{16}$ Polycrates of Ephesus, ${ }^{17}$ Tertullian (d. 225) prior to his Montanist period, ${ }^{18}$ Hippolytus (d. 235), ${ }^{19}$

${ }^{7}$ Fragments of Papias, 4, in Philip Schaff, ed., The Apostolic Fathers with Justin Martyr and Irenaeus, vol. 1 (Oxford: Benediction Classics, 2010), 1745. Further, the Didache suggests a chiliastic view of the Eschaton: Didache, 16:6-8 in Alexander Roberts, Sir James Donaldson, and Arthur Cleveland Coxe, eds., The Ante-Nicene Fathers:The Writings of the Fatbers Down to A.D. 325, vol. 7, Fathers of the Third and Fourth Century - Lactantius, Venantius, Asterius, Victorinus, Dionysius, Apostolic Teaching and Constitutions, Homily, Liturgies (New York: Cosimo), 2007,382.The larger text is hereafter cited: Roberts, Donaldson, and Coxe, eds., The Ante-Nicene Fathers.

${ }^{8}$ Justin Martyr, Dialogue with Trypho, in Roberts, Donaldson, and Coxe, eds., The Ante-Nicene Fathers, vol.1, The Apostolic Fathers with Justin Martyr and Irenaeus, 194-270. Hereafter cited: Martyr, Dialogue. Justin makes clear that millenarianism is a perfectly orthodox belief, held by a wide range of early Church persons.

${ }^{9}$ Irenaeus, Adv. Haer. 3.3.4., in Roberts, Donaldson, and Coxe, eds., The Ante-Nicene Fathers, vol. 1, 309-567. Hereafter cited: Irenaeus, Adv. Haer.

${ }^{10}$ It is said that Clement was the first pope, ordained by Peter as bishop. Tertullian, The Sacred Writings of Tertullian, extended annotated ed. (Altenmünster: Jazzybee Verlag, 2012), xxxii; St. Jerome, De Viris Illustribus, Ch.15, in William Henry Paine Hatch, A Manuscript of Jerome's De Viris Illustribus Belonging to the General Theological Seminary in New York (Lenox, MA: HardPress, 2012), 20. Clement of Rome, according to the commentary of Anastasias, subscribed to belief in the "millennial week," a notion that God limited history to six millennia, with the peaceful reign of Christ over the nations counting as the seventh millennium, the Sabbath Rest. See Anastasia's commentary on Clement in J. R. Baun, The "Apocalypse of Anastasia" in its Middle Byzantine Context, PhD diss., Princeton University, 1997, Proquest (304373080). See also Justin Martyr, "Other Fragments," in The First Apology, in Roberts, Donaldson, and Coxe, eds., The Ante-Nicene Fathers, vol. 1, 300-03. Hereafter cited: Martyr, The First Apology. See Boratius Bonar, "The Apostolocity of Chiliasm," The Quarterly Journal of Propbecy 2 (April 1850): 141-61, 159.

${ }^{11}$ James Carleton Paget, The Epistle of Barnabas: Outlook and Background (Tübingen: J.C.B. Mohr, 1994), 170.

${ }^{12}$ George Nathaniel Henry Peters, The Theocratic Kingdom of our Lord Jesus, the Christ, as Covenanted in the Old Testament (Grand Rapids, MI: Kregel, 1988), 495-96. Hereafter cited: Peters, The Theocratic Kingdom. Hegesippus lived in the sub-apostolic age and was a Hebrew Christian. Some scholars claim that Irenaeus was his pupil and that Irenaeus learned of the imminent understanding of eschatology and the material reign of Christ on earth under Hegesippus's tutelage. See also W. Telfer, "Was Hegesippus a Jew?" The Harvard Theological Review 53, no. 2 (1960): 143-53, 53. See Martyr, First Apology, 11.52. Hegessipus's section referencing the grandsons of Jude is almost identical to Justin Martyr's chiliastic statement in First Apology 11.52, in Justin Martyr and Thomas B. Falls, The Fathers of the Church, a New Translation, vol. 6, Saint Justin Martyr: The First Apology, The Second Apology, Dialogue with Trypho, Exhortation to the Greeks, Discourse to the Greeks, the Monarchy, or the Rule of God (Washington: Catholic University of America Press, 1948), 43. Justin here appears to argue that the kingdom is not earthly, but this was intentionally added to the First Apology so that the authorities of the Roman Empire would not conceive of his explicit chiliastic language as a desire to subvert the established polis and establish a messianic kingdom in its place.

${ }^{13}$ Greg Carey, Ultimate Things: An Introduction to Jewish and Christian Apocalyptic Literature (St. Louis: Chalice, 2005), 232. Cf. Pier Franco Beatrice, introduction to Anonymi Monophysitae Theosophia: An Attempt at Reconstruction (Boston: Brill Academic, 2001), xi-lix, xxxviii.

${ }^{14}$ W.D. Killen, The Ancient Church: Its History, Doctrine, Worship, and Constitution (Teddington, UK: Echo Library, 2010), 267. Cf. Peters, The Theocratic Kingdom, 495.

${ }^{15}$ David S. Katz and Jonathan I. Israel, eds., Sceptics, Millenarians, and Jews (New York: Brill Academic, 1990), 180. W.H.C. Frend states that Melito "was regarded in later tradition as a millenarian whose view of God tended toward the anthropomorphic." W. H. C. Frend, Rise of Christianity (Philadelphia: Fortress, 1986), 240. According to William Pym, in his Commentary on Ezekiel, St. Jerome describes Melito as a "decided millenarian." William Pym, Thoughts On Millenarianism, 2nd ed. (London: James Nisbet, 1829), 40. Further, Gennadius states that Melito awaited his own resurrection in millenarian form and subscribed to a Quartodecimian view consistent with the early millenarian Christians who borrowed these themes from Second Temple Jewish sources. Gennadius, De Eccl. Dog., in Philip Schaff and Henry Wace, eds., A Select Library of the Nicene and Post-Nicene Fathers of the Christian Church (London: Christian Literature, 1892), 372, $₫ 52$.

${ }^{16}$ Karl R. Hagenbach, History of Christian Doctrine V2 (Whitefish, MT: Kessinger, 2006), 139.

${ }_{17}$ Margaret M. Mitchell and Frances M. Young, eds., Origins to Constantine, The Cambridge History of Christianity, vol. 1 (New York: Cambridge University Press, 2006), 320. 
Cyprian (d. 258), ${ }^{20}$ Lactantius (d. 320), ${ }^{21}$ Victorinus, ${ }^{22}$ Commodian, ${ }^{23}$ Methodius of Olympus (d. 311), ${ }^{24}$ Ambrosiaster ( 366), ${ }^{25}$ and several others. ${ }^{26}$ Ambrose of Milan used specific millenarian language and appeared to subscribe to a dual-resurrection model. ${ }^{27}$ Another noteworthy proponent is St. Ephrem the Syrian, the fourth-century Doctor of the Church, whom Jerome classified "as millenarian." 28 Saints Justin and Irenaeus go to extreme lengths-perhaps in response to their Gnostic adversariesto express that millenarian eschatology is a primary mark of ortbodoxy. ${ }^{29}$ One modern scholar attributes "the chiliasm of Irenaeus to his respect for tradition, the "rule of faith." ${ }^{30}$ Irenaeus himself refers to apostolic tradition when he defends chiliasm against the Gnostics, and he warns that anyone who rejects both the bodily resurrection and the literal "millennial" reign of Christ are to be considered heretics. ${ }^{31}$ In addition to the evidence gleaned from well-respected early theologians, various pieces of non-textual evidence that point to consistent chiliastic expectations in the

\footnotetext{
${ }^{18}$ Tertullian, "A Treatise on the Soul (de Anima)," 55, in Alexander Roberts and James Donaldson, eds., The Ante-Nicene Christian Library: Translations of the Writings of the Fathers Down to A.D. 325, vol. 3, The Writings of Tatian and Theophilus; and the Clementine Recognitions (Boston: Adamant Media, 2001), 231. Cf. Dictionary of Biblical Criticism and Interpretation, ed. Stanley E. Porter (New York: Routledge, 2007), s.v. "Millenarianism."

${ }^{19}$ J. N.D. Kelly, Early Christian Doctrines, 5th ed. (London: Continuum, 2000), 468-69. Cf. Mal Couch, ed., A Bible Handbook to Revelation (Grand Rapids, MI: Kregel Academic \& Professional, 2001), 27.

${ }^{20}$ Peters, The Theocratic Kingdom, 496, n3b, bttps://archive.org/details/theocratickingdo03pete. Cyprian, like Hippolytus and the earliest Fathers, subscribed to the "millennial week" eschatology with a historical, Sabbath millennium to follow. Cyprian, Treatise 11; Preface, 2; On the Exhortation to Martyrdom, 11, http://www.newadvent.org/fathers/050711.htm. Here, Cyprian states that six thousand years had passed since "the devil first attacked man." This is common language among millenarians, expressed with a simultaneous expectation that those six thousand years are about to end, followed by a glorious seventh era corresponding to the millennial reign of Jesus Christ.

${ }^{21}$ Lactantius, Divine Institutes, in A. Roberts and J. Donaldson, eds., trans. W. Fletcher, Ante-Nicene Christian Library: Translation of the Writings of the Fathers down to A.D. 325, vol. 21, The Works of Lactantius, vol. 1 (Edinburgh, 1871), 480. Cf. Jeffrey K. Jue, Heaven Upon Earth:Joseph Mede (1586-1638) and the Legacy of Millenarianism (Dordrecht, The Netherlands: Springer, 2006), 121.

${ }^{22}$ Victorinus, On the Creation of the World, in Roberts, Donaldson, and Coxe, eds., The Ante-Nicene Fathers, vol. 7, 342 .

${ }^{23}$ Commodian, "Of the First Resurrection," in Roberts, Donaldson, and Coxe, eds., The Ante-Nicene Fathers, vol. 4, Tertullian, Minucius Felix, Commodian, and Origen, 199-220, 212.

${ }^{24}$ Methodius of Olympus, The Banquet, 9.5, in Herbert Anthony Musurillo and Victor Henry Debidour, Le banquet (Paris: Editions du Cerf, 1963), 216-19. Cf. Encyclopedia of Christian Theology, ed. Jean-Yves Lacoste, 2 vols. (New York: Routledge, 2005), s.v."Millenarianism."

${ }^{25}$ Everett Ferguson, Encyclopedia of Early Christianity, Garland Reference Library of the Humanities, 2nd ed., 2 vols, vol. 2 (New York: Garland, 1997), 239 and 479.

${ }^{26}$ Jean Daniélou, A History of Early Christian Doctrine Before the Council of Nicaea, Vol.3:The Origins of Latin Christianity (London:Westminster, 1977), 123.

${ }_{27}$ St. Ambrose, On the Holy Spirit (De Spiritu Sancto), Book 1, Ch. 14, 170, bttp://www.newadvent.org/fathers/34021.htm. Ambrose subscribed to a belief anticipating two physical resurrections during the final stages of history-one leading to the intermediate temporal reality, and the other leading to eternity. See Ambrose of Milan, On Belief in the Resurrection, Book 2, $\$ 108$, bttp://www.monachos.net/content/patristics/texts/73-ambrose-of-milan-on-belief-in-tberesurrection?'showall $=$ Estart $=2$.

${ }^{28}$ Le Roy Edwin Froom, The Prophetic Faith of Our Fathers, vol. 1 (Washington, DC: Review and Herald, 1950), 337.

${ }^{29}$ R. P. C. Hanson, introduction to Selections from Justin Martyr's Dialogue with Trypho, a Jew (New York: Association, 1964), 1xxx. Irenaeus, Adv. Haer., 4.34 and 5.28.3. For Justin's view that non-chiliastic interpretations tend to stretch outside the bounds of orthodoxy, see Thomas W. Petrisko, The Kingdom of Our Father (McKees Rocks, PA: Saint Andrew's, 1999), 52. See also Cyril Charles Richardson, ed., Early Christian Fatbers (New York: Simon \& Schuster, 1996), 351

${ }^{30}$ Christopher R. Smith, "Chiliasm and Recapitulation in the Theology of Irenaeus," Vigiliae Christianae 48, no. 4 (1994): 313-31, 314

${ }^{31}$ Irenaeus, Adv. Haer, 5.31 and 5.35.
} 
earliest Christian communities have surfaced. ${ }^{32}$

It is difficult to determine how a system of belief that held such wide and persistent allegiance for so long in the early Christian tradition could lose so much ground as to be relegated to the margins of acceptable doctrine; it was practically replaced by its metaphorical counterpart by the mid-fourth century. As C. Cooper puts it:

[F]rom the third to the fifth centuries Chiliasm was vigorously fought and ruthlessly put down, although it was not officially declared a heresy. It was all really rather awkward, because previously nearly everybody of note had been a Chiliast. . . between Chiliasm and the charge of heresy stands the canonization of Justin Martyr and Irenaeus. ${ }^{33}$

The later, Augustinian reading of the thousand year reign of Christ, along with the view of the court theologians, appears to be completely different from the original view of the earliest Fathers. Augustine saw the thousand years when Jesus would reign with the martyrs as symbolic of the Church era of history ${ }^{34}$ and the first resurrection simply as the baptism of converts to the Church. Eusebius ${ }^{35}$ and Tyconius $^{36}$ were bold in reinterpreting the reign as the Pax Romani-the forced era of peace made visible in messianic terms by the Roman Empire and its Christian, Messiah-like head, Constantine.

In "testing" the Patristic millenarian principles against the standards for authentic, orthodox development (as opposed to corruption of dogma), it makes sense to begin with the "canon" of the Gallic Christian writer St.Vincent of Lérins (d.445) and then move to the more complex and nuanced "Notes" outlined by Newman. ${ }^{37}$ Newman's own central vision for testing the development of doctrine rested on Vincent's phrase, profectus fidei, non permutatio-the perfection of the original and latent dogmatic concept, and not its utter replacement or change..$^{38}$ St.Vincent's most often-

${ }^{32}$ Bellarmino Bagatti, The Church from the Circumcision: History and Archaeology of the JudaeoChristians, Publications of the Studium Biblicum Franciscanum. Smaller Series (Jerusalem: Franciscan, 1971), 298.

${ }^{33}$ C. Cooper, "Chiliasm and the Chiliasts." Reformed Theological Review 29 (1970): 12, emphasis mine.

${ }^{34}$ Augustine states, "Ergo ecclesia et nunc est regnum Christi regnumque caelorum." ("Therefore, the Church even now is the kingdom of Christ and the kingdom of heaven"). Augustine, De civitate Dei 20.9, in Augustine and Mortimer Jerome Adler, The Confessions; The City of God; On Christian Doctrine, Great Books of the Western World, 2nd ed., vol. 16 (Chicago: Encyclopædia Britannica, 1990), 540. Hereafter cited: Augustine, De civitate Dei. For Augustine's view of Revelation 20's two resurrections, see William A. Jurgens, The Faith of the Early Fathers, vol. 3 (Collegeville: Liturgical, 1998), 103.

${ }^{35}$ Eusebius, Life of Constantine (Vit. Const), 4.14, bttp://www.newadvent.org/fathers/25024.htm. Cf. Jonathan Bardill, Constantine, Divine Emperor of the Christian Golden Age (Cambridge: Cambridge University Press, 2012), 342. On the Emperor portrayed as the vicar of Christ, see Glenn F. Chesnut, The First Christian Histories: Eusebius, Socrates, Sozomen, Theodoret, and Evagrius, 2nd ed. (Macon, GA: Mercer University Press, 1986), 154; see also W. Otten, "Between Divine Promise and Earthly Politics," in J.W. van Henten and A.W. J. Houtepen, eds., Studies in Theology and Religion, vol. 3, Religious Identity and the Invention of Tradition: Papers Read at a Noster Conference in Soesterberg, January 4-6, 1999 (Assen, The Netherlands: Royal Van Gorcum, 2001), 73.

${ }^{36}$ Kenneth B. Steinhauser, The Apocalypse Commentary of Tyconius: A History of Its Reception and Influence, European University Studies, Series 23, vol. 301, Theology (Frankfurt am Main: P. Lang, 1987 ), 131.

${ }^{37}$ For more on the relation between St. Vincent of Lérins and John Henry Newman, specifically in reference to early eschatology, see Steven D. Aguzzi, "The Hermeneutics of Heresy," in "Israel, the Church, and Eschatological Hope: Moltmann's Millenarianism and the Jewish-Catholic Question," (PhD diss., Duquesne University, 2013), 261-65.

${ }^{38}$ John Henry Newman, Sixth Note, "Conservative Action Upon its Past," in An Essay on the Development of Christian Doctrine, Ch. 5, \6, 201, bttp://www.newmanreaderorg/works/development/ chapter5.html\#section6. Cf. John McDade, "Development of Doctrine," in Adrian Hastings, Alistair Mason, and Hugh Pyper, eds., The Oxford Companion to Christian Thought (Oxford: Oxford University Press, 2000), 163-64, 163. 
quoted statement was manifest in his Commonitory of 432, written with the intent of creating a general rule whereby to distinguish Catholic truth from heresy. ${ }^{39}$ In it, Vincent claims that within "the Catholic Church itself, all possible care must be taken that we hold that faith which has been believed everywhere, always, by all." 40 Specifically, Vincent states that in order to ascertain the proper doctrine of the Church, the Council of Ephesus thought it would suffice "to show the agreement of ten fathers or principal doctors of the Church." ${ }^{41}$ The Newmanesque view of doctrine and its evolution is anticipated in Vincent's oft-ignored "second rule":

But someone will perhaps say: is there no progress of religion in the Church of Christ? Certainly there is progress, even exceedingly great progress. For who is so envious of others and so hateful toward God as to try to prohibit it? Yet, it must be an advance [profectus] in the proper sense of the word and not an alteration [permutatio] in faith. For progress means that each thing is enlarged within itself, while alteration implies that one thing is transformed into something else [aliquid ex alio in aliud]. It is necessary, therefore, that understanding, knowledge, and wisdom should grow [crescat] and advance [proficiat] vigorously in individuals as well as in the community, in a single person as well as in the whole Church and this gradually in the course of ages and centuries. But this progress must be made according to its own type, that is, in accord with the same doctrine, in the same meaning, and in the same judgment. ${ }^{42}$

In light of Vincent's canon and Newman's reevaluation of it, both of which have been used often by apologists to support doctrinal developments such as purgatory, the Immaculate Conception, and papal infallibility, ${ }^{43}$ we must ask whether millenarianism's decline was a matter of the way eschatology legitimately evolved as a result of formulation, or if the issue concerns the matter or content of the eschatology itself. ${ }^{44}$ Many indicators point to the fact that the stark move from millennial eschatology among the early Church Fathers to a strict anti-millennialism after Origen in the East, and Augustine in the West, was more of a total change in doctrine than a development of it. ${ }^{45}$ The apostolic tradition seems to have

\footnotetext{
${ }^{39}$ Vincent of Lérins, Commonitorium 2.4, lines 2-3, bttp://www.newadvent.org/fathers/3506.htm. Hereafter cited: Vincent of Lérins, Commonitorium. See also Jaroslav Pelikan, The Emergence of the Catbolic Tradition (100-600), The Christian Tradition: A History of the Development of Doctrine, vol. 1, 333-39.

${ }^{40}$ Vincent of Lérins, Commonitorium 2.6, lines 1-2.

${ }^{41}$ Charles Journet, The Church of the Word Incarnate:Vol. 1:The Apostolic Hierarchy (Lanham, MD: Sheed and Ward, 1955), 537. Joseph Clifford Fenton explains, in order for the consent of the early Church Fathers to be unanimous, "we need not demand an explicit declaration on the point from every one of the fathers of the Church. There is such consent when at least a moral unanimity of the fathers who bave actually dealt with this subject, teach the same doctrine as having been revealed by God... the apposition of one, or even of an inconsiderable number, to the teaching which is common with the rest, does not prevent common teaching from enjoying certain unanimity. The united voice of the fathers constitutes a real rule of faith.” Joseph Clifford Fenton, The Concept of Sacred Theology (Milwaukee, WI: Bruce, 1941), 136, emphasis mine.

${ }^{42}$ Vincent of Lérins, Commonitorium 23.1-12. For an annotated translation of the original Latin, see Thomas Guarino,"Tradition and Doctrinal Development: Can St.Vincent of Lérins Still Teach the Church?" Theological Studies 67 (2006): 34-72.

${ }^{43}$ Dave Armstrong, Development of Catbolic Doctrine: Evolution, Revolution, or an Organic Process? (Raleigh, NC: LuLu, 2007), 1.

${ }^{44}$ See Wolfhart Pannenberg, Systematic Theology, 3 vols., vol. 1, trans. Geoffrey Bromiley (Grand Rapids, MI:Wm. B. Eerdmans, 1991), 11

${ }^{45}$ Walter Kasper makes the following statement regarding doctrinal development: "We must not deviate today from the path of the early and patristic Church; but neither can we stand still on it. We must follow the path further, though certainly, eodem sensu, in the same sense or direction." Kasper, Theology and Church, trans. Margaret Kohl (New York: Crossroad, 1989), 103.
} 
transformed into an allegorical and symbolic system of eschatology that had once been taken literally, temporally, and historically-not merely as the promise of a transcendent heaven after death and a new earth after final judgment, but as one of an actual time of peace ushered in by the parousiac Christ.

Scholars have illustrated that millennialism was held widely within multiple geographical provinces prior to Origen. ${ }^{46}$ By contrast, amillennial literature is nonexistent and leaves one with silence during the first two centuries. ${ }^{47}$ In an exhaustive work on the concept of the kingdom of God in the Patristics, John F. Walvoord claims that "the first century is barren of any real support for the amillennial viewpoint. . [and] is a lost cause for amillennialism. The second century, like the first, is devoid of any testimony whatever for amillennialism, except at its close." ${ }^{48}$ In relation to Vincent's rule, this essay seeks to "rightly point back to Vincent's dictum that 'progress requires that the subject be enlarged in itself.' In order for the Church truly to possess a 'living' tradition, the tradition must be capable of being modified, even greatly modified, without radical 'alteration' of its essence." ${ }^{49}$

The question arises as to how a doctrine may appear to develop in a manner that reflects a total and undeniable shift in content. ${ }^{50}$ The most plausible explanation is that the eschatological apostolic deposit carried forward the customary, secondcentury Jewish view of the Last Days, which is still present in the Church today but is viewed with suspicion because of past abuses. The earliest Christian eschatological teaching expected some kind of restoration of Jerusalem at the onset of an interregnum period initiated during the bistorical (within time), second adventus of the Messiah - a time when the nations would flood into the Holy City. ${ }^{51}$ In these first Christian centuries, this framework was derived from the Jewish sources and reworked to illustrate how Jesus would return as a messianic king, a Davidic figure who would vindicate the martyrs and consummate the earthly, created order during

\footnotetext{
${ }^{46}$ Rita Hermon-Belot, "God's Will in History:The Abbe Grégoire, the Revolution and the Jews," in Karl A. Kottman, ed., Millenarianism and Messianism in Early Modern European Culture, Vol. 2, Catbolic Millenarianism: From Savonarola to the Abbé Grégoire (Dordrecht: Kluwer Academic, 2001), 91-100, 96. Hereafter cited: Kottman, Millenarianism.

${ }^{47}$ Regarding the Book of Revelation, Jeffrey K. Jue tells us that "when it was first delivered it was understood to be millenarian, since the early chiliasts were the only interpreters who denied neither its canonicity, nor its value for the early church."Jue, Heaven Upon Earth:Joseph Mede (1586-1638) and the Legacy of Millenarianism (Dordrecht: Springer, 2006), 112. See also Donald Fairbairn, "Contemporary Millennial/Tribulational Debates: Whose Side Was the Early Church On?" in Craig L. Blomberg and Sung Wook Chung, eds., A Case For Historic Premillennialism: An Alternative to "Left Bebind" Eschatology (Grand Rapids, MI: Baker Academic, 2009), 105-32, 117.

${ }^{48}$ Walvoord, The Millennial Kingdom: A Basic Text in Premillennial Theology (Grand Rapids, MI: Zondervan, 1983), 43.

${ }^{49}$ Craig Payne, What Believers Don't Have to Believe:The Non-Essentials of the Christian Faith (Lanham, MD: University Press Of America, 2006), 17, emphasis mine.

${ }_{50}$ There are currently two primary scholars who argue that chiliasm and amillennialism were present from the beginnings of the Christian community in the first century. One is Charles Hill, whose work we have determined hinges upon a very unstable hermeneutic. The second author, Clementina Mazzucco, follows Hill in his argument, but neither of these scholars use primary Patristic sources to support their case. See Clementina Mazzucco, "Il millenarismo Cristiano delle origini," in Renato Uglione, ed., "Millennium": L'attesa della fine nei primi secoli cristiani. Atti delle 3 giornate patristiche torinesi (Turin: CELID Editrice, 2002), 145-82.

${ }^{51}$ Though chiliasm was not the only eschatology attributable to the Jewish community at the time of Christ, it was by far the most common, and the one most borrowed by early Christian authors and utilized in the apocalyptic discourses of Jesus. See William Horbury, Messianism Among Jews and Christians: Biblical and Historical Studies (Edinburgh:T\&T Clark, 2003), 281.
} 
an historical interregnum period with Jerusalem at its center. ${ }^{52}$ However, the fact that the highly metaphorical and symbolic amillennial view-which is admittedly more palatable to modern sensibilities than its literal predecessor-took root later does not mean that the original, "primitive" view held by the Fathers should be considered an error, or that the latter,Augustinian view should de facto be considered the legitimate development of a latent, albeit historiographically absent, apostolic deposit. In fact, the millenarian view was more than simply acceptable opinion for the early Fathers-it was likened to a deposit of faith. The millenarian view passes Vincent's most stringent sequence for the ascertaining of valid doctrine, including Patristic approbation and the absence of conciliar censure:

What if in antiquity itself two or three men, or it may be a city, or even a whole province be detected in error? Then he will take the greatest care to prefer the decrees of the ancient General Councils, if there are such, to the irresponsible ignorance of a few men. But what if some error arises regarding which nothing of this sort is to be found? Then he must do his best to compare the opinions of the Fathers and inquire their meaning, provided always that, though they belonged to diverse times and places, they yet continued in the faith and communion of the one Catbolic Church; and let them be teachers approved and outstanding. And whatever he shall find to have been held, approved and taught, not by one or two only, but by all equally and with one consent, openly, frequently, and persistently, let him take this as to be held by him without the slightest hesitation. ${ }^{53}$

If, as we have seen, millenarian eschatology withstands the vigor of Vincent's canon, might it too withstand the tests of a sample of Newman's notes? Although Newman illustrates his theory of development using common Catholic doctrines such as the Real Presence of the Eucharist, purgatory, and original sin, eschatology in general remains an untested theological category. ${ }^{54}$ Newman generally avoided eschatological speculation, even as the Church has avoided defining too much in this regard, but he did hold various private opinions regarding both the resurrection and purgatory. ${ }^{55}$ What is important for the purpose of this essay is that Newman sets forth his seven "Notes" as real tests for orthodox development, or put negatively, as tests that night weed out heresy: (1) preservation of type, (2) continuity of principles, (3) power of assimilation, (4) logical sequence, (5) anticipation of its future, (6) conservative action

\footnotetext{
52 See, for example, F. Stanley Jones, "Jewish-Christian Chiliastic Restoration in Pseudo-Clementine Recognitions 1.27-71," in James M. Scott, ed., Restoration: Old Testament, Jewish, and Christian Perspectives (Boston: Brill Academic, 2001), 529-71.

${ }^{53}$ Vincent of Lérins, Commonitorium, 3.7-8.

${ }^{54}$ See John Henry Newman, An Essay On the Development of Christian Doctrine, Ch. 4, \$1-3, 122-65, bttp://www.newmanreaderorg/works/development/chapter4.btml. Hereafter cited: Newman, Development. All citations of Development are taken from NewmanReader.org. See also Newman's study of the earliest markers of the Christian faith in the first centuries in Development, Ch. 6, $\$ 1,210$.

${ }^{55}$ Peter C. Wilcox, Jobn Henry Newman, Spiritual Director, 1845-1890 (Eugene, OR: Pickwick, 2013), 198. Interestingly, Newman mentions an ancient tradition that has been used to disparage chiliasm: "Tradition tells us that the Apostle of love seconded his word with his deed, and on one occasion hastily quitted a bath because an heresiarch of the day had entered it." Development, Ch. 7, $85.1,347$. Further tradition has suggested the heretic mentioned was Cerinthus, and that his heresy was chiliasm. Yet this is an impossibility considering the tradition is penned by Irenaeus, himself a chiliast. See Irenaeus, Adv. Haer. 3.3.4, and Raymond E. Brown, The Epistles of John (New York: Doubleday, 1982), 770.
} 
upon its past, and (7) chronic vigor. ${ }^{56}$ The next section of this essay will explore Patristic millenarianism with regard to the first two tests: preservation of type and continuity of principles, found in the first and second notes in Chapter Five of Development. These notes are effectively linchpins for the others and can thus serve as a succinct source. ${ }^{57}$

\section{PATRISTIC MILLENARIANISM TESTED AGAINST NEWMANS NOTES: VALID DEVELOPMENT, CORRUPTION, OR NEITHER?}

John T. Ford tells us that Newman's first note alone could accomplish the purpose of the entire essay, ${ }^{58}$ and Newman dedicated a disproportionate length of the essay to its treatment. This first note, "Preservation of Type," refers to whether or not the "proportions of the developed form, however altered, correspond to those which belong to its rudiments." ${ }^{59}$ Newman used the analogy of biological change in nature to solidify his point: "The adult animal has the same make as it had on its birth; young birds do not grow into fishes, nor does the child degenerate into the brute, wild or domestic, of which he is by inheritance lord." ${ }^{0}$ Therefore, even with seemingly radical change, a valid doctrinal development retains the key and root principles of its subject. For millenarian eschatology, these "first-principles" ${ }^{11}$ came from the Hebrew Bible, certain rabbinic sources, and the overarching apocalyptic expectations of the Second Temple period. They culminated in the Johannine conception of an expectation for a material, messianic kingdom upon the return of Jesus, a sentiment also found throughout the entire New Testament. ${ }^{62}$ The millenarian worldview had its antecedents during the early apostolic period, ${ }^{63}$ making it not

\footnotetext{
${ }^{56}$ Newman, Development, Ch. 5. \$1-7, 169-206. Newman summarizes his theory as follows: "There is no corruption if it retains one and the same type, the same principles, the same organization; if its beginnings anticipate its subsequent phases, and its later phenomena protect and subserve its earlier; if it has a power of assimilation and revival, and a vigorous action from first to last. On these tests I shall now enlarge, nearly in the order in which I have enumerated them." Development, Ch. 5, \$3, 171.

${ }^{57}$ John T. Ford cautions against indiscriminate use of Newman's notes for ascertaining proper doctrinal development in the modern sense of theology. Ford, "Faithfulness to Type in Newman's Development of Doctrine," in The Proceedings of the Wethersfield Institute, Vol. 1: Newman Today, ed. Stanley L. Jaki (San Francisco: Ignatius, 1989), 17-48, 18. Hereafter cited: Ford, "Faithfulness."Yet other scholars have made the attempt, resulting in fruitful scholarship and thoughtful insights regarding otherwise forgotten or diminished areas of systematic theology. For example, see Gerald O'Collins, S.J., "Newman's Seven Notes: The Case of the Resurrection" in Ian Ker and Alan G. Hill, eds., Newman After a Hundred Years (Oxford: Clarendon, 1990), 337-52.

${ }^{58}$ Ford, "Faithfulness," 18.

${ }^{59}$ Newman, Development, Ch. 5. $\$ 1-7,171-72$.

${ }^{60}$ Ibid., 172, emphasis mine.

${ }^{61}$ Ibid., 172.

${ }^{62}$ Kasper, Jesus the Christ (London and New York: Burns \& Oates and Paulist, 1976), 73. Cf. R. Kendall Soulen, The God of Israel and Christian Theology (Minneapolis: Fortress, 1996), 131-32.

${ }^{63}$ See Daley, "Eschatology in the Early Church Fathers," in The Oxford Handbook of Eschatology, ed. Jerry L. Walls (New York: Oxford University Press, 2008), 98-99; see also "The Fragments of Papias," in Roberts, Donaldson, and Coxe, eds., The Ante-Nicene Fathers, vol. 1, 406-17. One of the earliest extant sources for chiliasm comes from the writings of Papias, "an ancient man, who was a hearer of John, and a friend of Polycarp." Irenaeus, Adv. Haer, 5.33; Cf. 2 Baruch, in Michael E. Stone and Matthias Henze, 4 Ezra and 2 Baruch: Translations, Introductions, and Notes (Minneapolis: Fortress Press, 2013), Ch. 29, 38. For a thorough argument regarding Papias's interactions with the apostle John and his chiliastic traditions, see D.A. Carson and Douglas J. Moo, An Introduction to the New Testament, 2nd ed. (Grand Rapids, MI: Zondervan, 2005), 233-34. See also R. C. Foster, Studies in the Life of Christ: Introduction, The Early Period, The Middle Period, The Final Week (Joplin, MO: College, 1995), 173-74. Cf. Walter J. Burghardt, Michael Newman, and Johannes Quasten, eds., The Didache;The Epistle of Barnabas;The Epistles and the Martyrdom of St. Polycarp; The Fragments of Papias; The Epistle of Diognetus (Whitefish, MT: Literary Licensing, 2011), 108-10.
} 
merely a development of dogma, but perhaps a rudiment itself, "a weighty testimony to primitive Christian eschatological beliefs." ${ }^{64}$ The question that arises is whether the various millenarian beliefs that have surfaced in Roman Catholic history, ${ }^{65}$ both those materialistic in form and those more spiritualized (as in the works of Joachim of Fiore), are legitimate or illegitimate developments of that original expectation for an earthly and historic era of messianic peace on earth. Another indirectly related question is whether the later amillennialism - which by its very name conceives of the millennial description in Revelation 20 as either nonexistent or metaphorical and applicable to the Church of history-is a valid development of an original type. If the more extreme amillennial paradigm, along with its historicized and realized forms, ${ }^{66}$ was a development of the earlier millenarian principle, we likely would not see such antagonism between its proponents and the chiliasm that came before $i^{67}$ - but it is difficult to state this definitively. The consistent Roman Catholic view appears to maintain a balance between the "already" and the "not-yet" of the kingdom's manifestation, a position that was confirmed during the Second Vatican Council. ${ }^{68}$

Newman challenged the idea that extreme variance, even as radical as the case just described, inherently amounts to the corruption of an original idea: "[I]t may happen that a representation which varies from its original may be felt as more true and faithful than one which has more pretensions to be exact," ${ }^{69}$ and again:"one cause of corruption in religion is the refusal to follow the course of doctrine as it moves on, and an obstinacy in the notions of the past." ${ }^{70}$ Newman considered one of the fatal flaws of Protestantism to be the stubbornness of insisting on a simplified, "pure

${ }^{64}$ B. Bandstra and S.S. Stuart, "Millennium," in Geoffrey W. Bromiley, ed., International Standard Bible Encyclopedia, Volume 3: K-P, rev. ed. (Grand Rapids, MI:Wm. B. Eerdmans, 1995), 358.

${ }^{65}$ See Richard K. Emmerson and Bernard McGinn, eds., The Apocalypse in the Middle Ages (Ithaca, NY: Cornell University Press, 1993), 20-37, and Kottman, Millenarianism, 96. Cf. Massimo Introvigne, "Catholic Apocalypticism and the Army of Mary," in Stephen Hunt, ed., Christian Millenarianism: From the Early Church to Waco (Bloomington: Indiana University Press, 2001), 151.

${ }^{66}$ Jürgen Moltmann claims that what we now call "amillennialism" is in fact a kind of "historical millenarianism" or "presentative millenarianism" in which the thousand-year reign of Christ is reconceived as taking place either ecclesiastically or politically. Moltmann, The Coming of God: Christian Eschatology (London: SCM, 1996), 146; 192-94; 197. Cf. Scott Bader-Saye, Church and Israel after Christendom: The Politics of Election, Radical Traditions, (Boulder, CO: Westview, 1999), 56-59.

${ }^{67}$ The early Eusebius, as a historian, could not deny the apostolic nature of chiliasm, simply because of its validity and well-documented development in the early Church. Eusebius, in a section on Dionysius's debate with the chiliasts of Egypt (the Church in Arsenoita), quotes Dionysius as implying that it was not merely local elders, but also those whom the early Fathers called 'doctors,' who held to the chiliastic eschatology early on. In addition, whole congregations espoused the doctrine, as is evidenced by Dionysius's use of the words 'many of the brethren.' See G. Gillespie, Notes of Debates and Proceedings of the Assembly of Divines and Other Commissioners at Westminster, Feb. 1644 to Jan. 1645 (Charleston, SC: Nabu, 2010), 27, in which he makes reference to the Syriac version of Eusebius, Historia Ecclesiastica, 7.23. For the original text, see Eusebius, Historia Ecclesiastica, bttp://www.newadvent.org/ fathers/250107.htm. Hereafter cited: Eusebius, Hist. Eccl. For Eusebius's later disparaging of millenarianism, sometimes subtle while at other times direct, see De laudibus Constantini, Book 1, Ch. 9, bttp://www.newadvent.org/fatbers/25021.htm and Book 4, Ch. 10, bttp://www.newadvent.org/ fathers/25024.htm. See further, Hist. Eccl., Vita Constantini., and Sabine MacCormack, "Latin Prose Panegyrics," in Thomas Alan Dorey, ed., Empire and Aftermath: Silver Latin 2 (London: Routledge \& Kegan Paul, 1975), 168.

${ }^{68}$ See Lumen Gentium 5, in Austin Flannery, Vatican Council II: The Basic Sixteen Documents, Vatican Collection: the Basic Volume (Dublin: Dominican, 1996), 58-66. For a critical view regarding the dangers of emphasizing the "not-yet" of the kingdom, see Henri de Lubac, Gebeimnis aus dem wir leben (New York: Einsiendeln/Benziger, 1967), 111. De Lubac quotes both Augustine and Origin in this section, but the earlier Fathers are unrepresented.

${ }^{69}$ Newman, Development, Ch. 5, §1.7, 176.

${ }^{70}$ Ibid., 177. 
seed"71 interpretation of the primitive, ad fontes teachings of the early church over the valid developments made throughout the centuries-a flaw he categorized as pharisaical. ${ }^{72}$ However, Newman's overall rationale for the theory of development, consistently with his first note, was quite conservative with regard to drawing out definitive points of continuity with the earliest dogmas. Newman expresses this in his Apologia: "The fact of the operation from first to last of the principle of development in the truths of Revelation, is an argument in favour of the identity of Roman and Primitive Christianity." 73 If we are to take this claim seriously, we must ask if there is not still a place for some form of millenarian eschatology within the Roman Catholic tradition-perhaps a form that is still in the process of developing. Millenarian and amillennial views may be seen as developing in ecclesial history, given that the former is attested early and normatively and the latter cannot be neglected because Augustine's view was embraced so rapidly, perhaps as a further development of alternative latent ideas. ${ }^{74}$ The two eschatological systems enjoyed a degree of prominence and persistence among the fourth century Fathers, garnishing papal support and wide popularity in reference to the sensus fidelium. ${ }^{75}$ In short, it appears that both Patristic millenarian beliefs and the later allegorized amillennialism pass the test in Newman's first note as possible "preservations of a type" that came before-during the primitive, apostolic period for chiliasm, and during development in the later third century for the amillennial view.

Newman states that "the continuity or the alteration of the principle on which an idea has developed is a second mark of discernment between a true development and a corruption.. ${ }^{76}$ For Newman, continuity of principles meant first principles, or unchanging laws "which doctrines embody in their development." The principles are more akin to ethical and practical attributes, as "systems live in principles and represent doctrines." ${ }^{\prime 8}$ Instead of applying the second note to various examples, Newman lists nine principles inherent in legitimate development, and focuses on four: faith, theology, the mystical sense, and dogma. ${ }^{79}$ Applied strictly, millenarianism may be legitimized by all these, save perhaps the mystical reading of Scripture.

First, Newman places a priority on faith, even in spite of logical proof: "I do not mean of course that the Fathers were opposed to inquiries into the intellectual basis of Christianity, but that they held that men were not obliged to wait for logical proof before believing; on the contrary, that the majority were to believe first on

${ }^{71}$ Steven D.Aguzzi, “John Henry Newman's Anglican Views on Judaism," Newman Studies Journal 7, no. 1 (2010): 56-72, 59, n. 16.

${ }^{72}$ Newman, "On Preaching the Gospel," in Lectures on the Doctrine of Justification, Lecture 13.5.2, 324, bttp://www.newmanreaderorg/works/justification/lecture13.btml.

${ }^{73}$ Newman, Apologia pro Vita Sua, Ch. 4, \& 2.6, 199, bttp://www.newmanreaderorg/works/apologia65/ chapter4-2.btml, emphasis mine.

${ }_{74}$ Pope Benedict XVI, Jesus of Nazareth (New York: Doubleday, 2007), 49-50.

${ }^{75}$ See Ormond Rush, The Eyes of Faith:The Sense of the Faithful and the Church's Reception of Revelation (Washington, D.C.: Catholic University of America Press, 2009), 241; see also Abbas Amanat and Magnus Bernhardsson, Imagining the End:Visions of Apocalypse from the Ancient Middle East to Modern America (London: I.B. Taurus, 2002), 167.

${ }^{76}$ Newman, Development, Ch. 5, §2.6, 185.

${ }^{77}$ According to James C. Livingston, Newman's “continuity of principles" meant first principles, or unchanging laws "which doctrines embody in their development." Livingston, "John Henry Newman," in James C. Livingston et al., Modern Christian Thought (Minneapolis: Fortress, 2006), 200-213, 204.

${ }^{78}$ Newman, Development, Ch. $5, \$ 2.1,178$, emphasis mine.

${ }^{79}$ Ibid., Ch. 7, 1.4, 325. 
presumptions and let the intellectual proof come as their reward." ${ }^{80}$ Justin exemplifies the simple faith of the Church regarding chiliasm when he states that "I and others who are right-minded Christians on all points are assured that there will be a resurrection of the dead, and a thousand years in Jerusalem, which will then be built[.]" ${ }^{81}$ Irenaeus makes a similar claim in reference to the blessing of Jacob, which "belongs unquestionably to the times of the kingdom when the righteous will bear rule, after their rising from the dead. It is also the time when the creation will bear fruit with an abundance of all kinds of food[.]" 82

Second, there was and is a complex theology of millenarian belief, from the early Catholic Church to this day-a theological heritage indirectly cited as proof of proper development. ${ }^{83}$ Irenaeus points to the source of this theology as Johannine: "And these things are borne witness to in writing by Papias, the hearer of John, and a companion of Polycarp, in his fourth book," while modern scholarship attests to its longevity. ${ }^{84}$ Systematic studies reveal consistent and sustained millenarian faith from the primitive apostolic period, even through the fourth century and beyond, and show that there was no opposition to the eschatology prior to Origen, save among prominent heretics. ${ }^{85}$ This millenarian faith was not formally codified, yet neither were now-traditional beliefs such as the sinless nature of Jesus, the sinless nature of Mary, the Immaculate Conception, the primacy of the Pope, and various other important doctrines. But are we to assume that, because the early expectation of the Thousand Year Reign is missing from the Apostle's Creed, it held no part in apostolic tradition, or was never handed down orally as part of the apostolic deposit? One thing we do see is that the earliest influences on the Apostle's Creed were markedly millenarian-a sign of an early but sustained doctrinal development. ${ }^{86}$

\footnotetext{
${ }^{80}$ Ibid, Ch. 7, 2.4, 330.

${ }^{81}$ Justin Martyr, Dialogue Ch. 80, 239. Justin, along with Irenaeus, insisted that human history's thousandyear interregnum would take place prior to the new creation, setting it in contrast with amillennialism. Some place emphasis on Justin's comment in the Dialogue that "many who belong to the pure and pious faith, and are true Christians, think otherwise" (239). But this is almost certainly an interpolation by a later redactor. On this point, see commentary by Arthur Lukyn Williams, trans.,Justin Martyr, the Dialogue with Trypho (London: S.P.C.K., 1930), 83, and Timothy J. Horner, Listening to Trypho:Justin Martyr's Dialogue Reconsidered (Sterling, VA: Peeters 2002), 46.

${ }^{82}$ Irenaeus, Adv. Haer, 5, 32-33, emphasis mine.

${ }^{83}$ Of the Fathers Newman cites as reliable sources for investigative theology, at least three were millenarians: "Reason has ever been awake and in exercise in the Church after Him from the first. . the Martyr Ignatius, in his way to the Roman Amphitheatre, wrote his strikingly theological Epistles; he was followed by Irenceus, Hippolytus, and Tertullian [.]"Development, Ch. 7, 3.3, 338.

${ }^{84}$ Irenaeus, Adv. Haer, 5, 33.4, bttp://www.newadvent.org/fathers/0103533.htm. Cf. Catherine Wessinger, ed., The Oxford Handbook of Millennialism (New York: Oxford University Press, 2011). Hereafter cited:Wessinger, Oxford Handbook.

${ }^{85}$ See Martin Erdmann, The Millennial Controversy in the Early Church (Eugene, OR: Wipf and Stock, 2005).

${ }^{86}$ J.P. Kirsch hastily makes the claim that "in spite of the defense by prominent Fathers of the Church, millenarianism was never held in the universal Church as an article of faith based on Apostolic tradition." Kirsch, "Millennium," in Charles G. Herberman, The Catbolic Encyclopedia: An International Work Of Reference On The Constitution, Doctrine, Discipline, And History Of The Catholic Church, Volume 10 (Charleston, SC: Nabu, 2010), 308-09.A more detailed study reveals that the one purpose for the Father's defense of chiliasm was to defend against heresy. A thorough study of the origins of the Apostle's Creed suggests that chiliastic statements were left out of it simply because they were taken for granted as true, while the three canons that were directly quoted in the Apostles Creed in various phraseological forms (no less than fourteen phrases), all came from staunch millenarians: "[T]he ultimate root of both symbols is imbedded in Eastern soil. . . in Tertullian, Irenaeus, and Justin the Martyr[.]" See Conrad Moehlman, "The Origin of the Apostles' Creed," The Journal of Religion 13, no. 3 (July 1933): 301-19, and Everett Ferguson, "Creeds, Councils, and Canons," in Susan Ashbrook Harvey and David Hunter, eds., The Oxford Handbook of Early Christian Studies (Oxford: Oxford University Press, 2008), 431.
} 
Third, in his section on the principle of "dogma," Newman makes reference to the dangers of "private opinion" common in Evangelical circles, when he states that

[S] uch a principle, however, would but have broken up the Church the sooner, resolving it into the individuals of which it was composed, unless the Truth, to which they were to bear witness, had been something definite, and formal, and independent of themselves. Christians were bound to defend and to transmit the faith which they had received, and they received it from the rulers of the Church; and, on the other hand, it was the duty of those rulers to watch over and define this traditionary faith. ${ }^{87}$

Again, it is fascinating that the three primary Fathers that Newman cites regarding conservative and definitive action upon Apostolic dogmatic tradition were all unwavering advocates of chiliasm, ${ }^{88}$ while the heretics they refuted-the Gnostics and Marcionites, whom Newman also mentions by name ${ }^{89}$ were the first to reject chiliastic eschatology. Newman points out that the rationale for evaluating both heresy and truth, used among the early Catholic writers, relates to a concept of familiarity:

[T] he reason they commonly gave for using the anathema was that the doctrine in question was strange and startling, it follows that the truth, which was its contradictory, was also in some respect unknown to them hitherto; which is also shown by their temporary perplexity, and their difficulty of meeting heresy, in particular cases. "Who ever heard the like hitherto?" says St. Athanasius, of Apollinarianism..$^{90}$

In this sense, the millenarian impetus would have been quite familiar to the Fathers, through the fourth century, as a commonly known extension of the apostolic deposit. Yet as the fourth century emerged, Fathers such as Augustine, dealing with the disappointments of history (i.e., the fact that Jesus had not yet returned), began to codify and formalize the alternative eschatological model and interpretation of the reign of Christ-one that put the historical Church in closer proximity to the kingdom of God.The fact that the "truth" of Augustine's model of the kingdom would have been foreign to the minds of Irenaeus, Justin, and Tertullian does not mean that it is not a legitimate development of some dogmatic principle.

The fourth and final of the sub-principles in Newman's second note regarding the continuity of principles is that of the mystical interpretation of Scripture. Here, to my knowledge, is the sole occurrence in which Newman specifically references the millenarian impetus:

Now it was Scripture that was made the rule on which this development proceeded in each case, and Scripture moreover interpreted in a mystical sense;

\footnotetext{
${ }^{87}$ Newman, Development, Ch. 7, $\$ 5.3,348-49$.

${ }^{88}$ Ibid., 329, 338, and 349. Newman mentions Irenaeus, Polycarp and Tertullian. Of the three, Irenaeus and Tertullian were undoubtedly millenarian; Polycarp's Quartodecimianism is well documented, but his chiliasm is disputed. Some scholars see Polycarp "locating the reign of the saints after the coming of Jesus and the resurrection of the saints, but before the general resurrection," all chiliastic principles. Lewis Sperry Chafer, Systematic Theology, Vol. 1, Systematic Theology Series (Grand Rapids, MI: Kregel, 1993), 272.

${ }^{89}$ Newman, Development, Ch. 7, \$5.3,349.

${ }^{90}$ Ibid., Ch. $7, \$ 3.6,351-52$. It is important to clarify, for the purposes of this essay, that contrary to the implications of popular scholarship, Apollinaris was never declared a heretic for his support of millenarianism, but instead for his rejection of the idea that Christ had a real soul (the Logos-Sarx heresy originating in Origen). F. Ocáriz, L.F. Mateo Seco, and J.A. Riestra, The Mystery of Jesus Christ:A Christology and Soteriology Textbook (Dublin: Four Courts, 1998), 58.
} 
and, whereas at first certain texts were inconsistently confined to the letter, and a Millennium was in consequence expected, the very course of events, as time went on, interpreted the prophecies about the Church more truly, and that first in respect of her prerogative as occupying the orbis terrarum, next in support of the claims of the See of St. Peter. This is but one specimen of a certain law of Christian teaching, which is this, $-a$ reference to Scripture throughout, and especially in its mystical sense. ${ }^{91}$

It is notable that Newman himself did not conceive of a literal Thousand Year Reign of Christ, but he is both generous to the earlier interpretation and keen to point out a further development of it utilizing the principle of mystical interpretation. ${ }^{92}$ Assuming that Revelation 20 is a "prophec[y] about the Church," as Newman states (and this is a considerable assumption), it is the course of bistorical events that promoted the development of the Augustinian, ecclesiological model, which is based on a mystical reading and not a literalistic one. Jesus had not yet returned, the Church was still persecuted, but it existed on the heels of a synthesis with a political Christendom. Thus, it made no sense to cling to antiquated dreams of a millennial reign "occupying the orbis terrarum" when the reign of Christ on earth could simply be conceived as taking place commensurate with the Church militant. Importantly, Newman does not say that the millenarian interpretation is not true, but simply that the events of history dictated that the prophetic utterances, when applied to the Church, were done so "more truly," using the mystical sense. The millenarian impetus and its later amillennial interpretation are conceived as "a reference to Scripture throughout," but "especially in its mystical sense." It is also important to remember that under the development of doctrine, the very course of events, as time goes on, may be influential in reinterpreting prophetic texts. Doctrinal statements are neither static nor based on an excessive epistemological rigidity. ${ }^{93}$

\section{PATRISTIC MILLENARIANISM AND THE CONTEMPORARY EUCHARISTIC INTERPRETATION: A DEVELOPMENT OF DOCTRINE?}

One aspect of reinterpretation that points to a potential ongoing doctrinal development in reference to millenarianism is a rather recent Catholic theological inquiry appropriately categorized as "Eucharistic millennialism." In 1990, Catholic theologian Fr. Marino Penasa asked the then Cardinal Joseph Ratzinger, in a direct manner, about an "imminent, intermediate, millenary reign of Jesus Christ, prior to the final judgment." ${ }^{94}$ Cardinal Ratzinger's answer was succinct, but consistent with past statements by the Magisterium:"Giacché la Santa Sede non si é ancora pronunciata in modo definitivo" ("The Holy See has not yet made any definitive pronouncement in

\footnotetext{
${ }^{91}$ Newman, Development, Ch. 7, $₫ 4.1,338-39$.

${ }^{2}$ Note that Newman does not describe the early interpretation of the Millennial prophecy as "heretical." At the risk of being anachronistic, it is important to remember that there is enough scholarly information now to question Newman's statement that the "claims of the See of St. Peter" have been formalized as amillennial.

${ }^{93}$ For Newman's views on philosophical certainty and the role of theology, see Kevin Mongrain, "Newman On Theology and Contemplative Receptivity in the Liberal Arts," Newman Studies Journal 4, no. 2 (Fall 2007): 11-20, 15.

${ }^{94}$ The final question asked by Fr. Penasa was "[W] hat of an imminent, future era of vital Christianity?," but the context of the discussion and of Fr. Penasa's work was an imminent future involving the peaceful reign of Jesus Christ on earth.
} 
this regard"). ${ }^{95}$ There is a degree of debate as to whether Cardinal Ratzinger meant that the past pejorative declaration on millenarianism (made by Pope Pius XII in $1944)^{96}$ was not a definitive proclamation, or whether he thought Penasa was referring to an End-Times, spiritualized, millenary reign of the Church rather than an era of peace constituted by a personal, eschatological reign of Jesus Christ in his resurrected body-i.e., Patristic millenarianism. It is Fr. Penasa's version of millennialism that makes one question the exact context of his interaction with the Cardinal, as Penasa himself adheres to and openly promotes a version of Patristic chiliasm that includes a chronology of an "intermediate Parousia" of Christ in the body, and an "earthly joyous millennium."

It is possible that Cardinal Ratzinger knew the context of Penasa's question and the priest's theological commitments, and simply admitted that the Church had not declared on the matter in such a way as to formally denounce millenarianism as heresy. However, it is more likely that the Cardinal believed Penasa was asking about a form of contemporary Catholic millennialism that differs from Patristic millenarianism insofar as the former does not admit of an earthly reign of Jesus in his resurrected body, whereas the latter does. In this contemporary, acceptable form of Catholic millennialism, theologians allow for a new millennial age prior to the final judgment, sometimes conceived as an era of the spiritual reign of the Virgin Mary with expectations of increased apparitions (supported by Pope John Paul II). ${ }^{98}$ Alternatively, this millennialism anticipates a reign of the Holy Spirit, or a renewed, invigorated, and refocused reign of Jesus Christ in bis Eucharistic Presence through the sacerdotal offices of the Church-a kind of "Great Awakening" among the faithful regarding the Eucharist, all leading up to the Parousia of Jesus. Common to all three "approved" versions of Catholic millennialism is the notion that the Roman Catholic Church is expanding during the future interregnum millennial age, gaining in charisma, popularity, and converts.

Much of this new wave of Catholic millennialism is associated with the work of

\footnotetext{
${ }_{95}$ Martino Penasa, "È imminente una nuova era di vita cristiana?" Il Segno del Soprannaturale 30, no. 10 (1990): 1-15, 10 .

${ }_{96}$ Pope Pius XII made the statement that mitigated versions of millenarianism "cannot be safely taught." Pope Pius XII, "Decree of the Holy Office." Mary Ann Collins argues that Pius XII's comments are to be taken within the context of a post-World War II environment and not as an indication that millenarian belief was considered heretical across the board. See Collins, Another Side of Catholicism: Insights from a Former Catbolic Nun (Lincoln, NE: iUniverse, 2004), 10. Cardinal Joseph Ratzinger (later Pope Benedict XVI), who appeared to understand Pius XII's statement in a more complex manner, leaves room for discussion on the role of certain millenarian eschatologies in Roman Catholic theology. He further argues that papal statements themselves must be called into question if they appear to be contrary to Scripture, or to a widely attested early Tradition. See Joseph Ratzinger, Das neue Volk Gottes: Entwürfe zur Ekklesiologie (Munchen: Patmos, 1969), 73.

${ }_{97}$ Martino Penasa, Viene Gesú! La venuta intermedia del Signore (Udine, Italy: Edizioni Segno, 1994). Massimo Introvigne, in his essay "Modern Catholic Millennialism," refers to the "book published by Father Martino Penasa claiming that Catholics could believe in an imminent 'intermediate coming' of Jesus Christ on Earth to inaugurate a thousand-year reign of the saints prior to the final judgment. ... Although the terminology was different, Penasa's ideas appeared to be more similar to classical Christian premillennialism." Introvigne, "Modern Catholic Millennialism," in Wessinger, Oxford Handbook, 549-66, 549-50. Hereafter cited: Introvigne, "Modern Catholic Millennialism."

${ }^{98}$ John Paul II explicitly backed the work of Catholic millennialist St. Grignion de Montfort (1673-1716). Montfort wrote of a "reign of Christ" in the last days, and a millennial "age of Mary." Jean Seguy, "Millénarisme et 'Ordres Adventistes': Grignion de Montfort et les Apôtres des derniers temps," Archives des sciences sociales des religions 53 (1982): 23-38. John Paul II's motto of Marian devotion, "All Yours," came directly from the work of Montfort, as he mentions himself in Pope John Paul II, Rosarium Virginis Mariae: Apostolic Letter On the Most Holy Rosary (London: Catholic Truth Society, 2002), \$15. See also Introvigne, "Modern Catholic Millenarianism," 552.
} 
Fr. Joseph Iannuzzi. In his book entitled The Triumph of God's Kingdom in the Millennium and End Times, Iannuzzi claims that although the early Fathers' belief in an interregnum millennial period as part of the regula fidei is undisputed, ${ }^{99}$ it was defined by the reign of Christ in the Eucharist-thus, Jesus was conceived of as reigning bodily, but through a renewed devotion to the Mass. ${ }^{100}$ In this sense, Iannuzzi's interpretation may in fact be a valid example of the development of doctrine.This conception or interpretation of the traditional, Patristic millennial reign of Jesus as a Eucharistic reality appears to fulfill two functions. First, it validates the interpretive mechanism of the earliest Church Fathers (Justin, Irenaeus, and Tertullian) insofar as they utilized language describing Jesus as reigning "in the flesh." Second, it balances this notion with the most dominant view of the millennium in Catholic history, namely, Augustine's emphasis on the reign of Christ as taking place within the Church of history. Here, Newman's understanding of the process of the development of ideas is telling:

The idea which represents an object or supposed object is commensurate with the sum total of its possible aspects, however they may vary in the separate consciousness of individuals; and in proportion to the variety of aspects under which it presents itself to various minds is its force and depth, and argument for its reality. Ordinarily an idea is not brought home to the intellect as objective except through this variety; like bodily substances, which are not apprehended except under the clothing of their properties and results, and which admit of being walked round, and surveyed on opposite sides, and in different perspectives, and in contrary lights, in evidence of their reality. ${ }^{101}$

Eucharistic Millennialism appears to express a resurgence of "survey[ing]" the eschatology of the first five centuries of Christianity "on opposite sides, and in different perspectives, and in contrary lights," evaluating and attempting to make sense of the "separate consciousness of individuals" (Justin, Ireaneus and Tertullian on one hand, and Augustine and Eusebius on the other). If, as Newman asserts, a valid doctrinal development is known generally by its adherence to the seven notes, but most critically through the first two-preservation of type and continuity of principles, the Eucharistic millennial interpretation could be conceived as an authentically developed interpretation of the eschatology of the earliest Fathers. Because this type is a more literal one, Eucharistic millennialism maintains the view that Jesus will in fact reign bodily during a period of time prior to the final consummation, but it likewise interprets that reign through a mystical reading, that is, by emphasizing the importance of the Church's role during the millennial era, of Augustine's later view. In this sense, one can consider this Eucharistic interpretation of the millennium of Revelation 20 as a very contemporary example of Newman's valid doctrinal development.

\footnotetext{
${ }^{99}$ Iannuzzi is correct in that the early chiliast Fathers defended the millennial reign as a notion to be included in the apostolic and sub-apostolic deposit of faith. See J.A. Cerrato, Hippolytus between East and West:The Commentaries and the Provenance of the Corpus (New York: Oxford University Press, 2002), 229.

${ }^{100}$ Referring to Lactantius's millennial doctrine, Iannuzzi claims that when the Father states that "Christ will be engaged among men a thousand years," he "does not refer to Christ's carnal reign in the flesh but to his universal reign in the Eucharist." Joseph Iannuzzi, The Triumph of God's Kingdom in the Millennium and End Times:A Proper Belief from the Truth in Scripture and Church Teachings (Havertown, PA: St. John the Evangelist, 1999), 40.

${ }^{101}$ Newman, Development, Ch. 1, $\$ 1.2,34$
} 


\title{
APOLOGIA PRO VITA STULTI: NEWMANS DEFENSE OF THE "SUPERSTITIOUS MASSES"
}

\author{
JONATHAN MARTIN CIRAULO
}

\begin{abstract}
This essay analyzes Newman's response to the tendency in philosophical modernity and liberal Protestantism, as exemplified by Jobn Locke, to denigrate the so-called "superstitious" nature of the religion of the masses. Newman constructed a philosophical and theological defense of Christians who were accused of an unenlightened superstition, due to their popular piety and lack of theological training, and proposes this very "superstition" to be the hallmark of genuine Christianity, as found from its inception. The essay concludes with a comparison to Augustine's City of God.
\end{abstract}

$\mathrm{O}$ f the many stereotypes that we use to classify the Middle Ages, particularly as it differs from the modern era, perhaps none is as common as the assumption that it was a highly dualistic society, with the privileged elite standing in stark contrast to a peasant majority. In religious terms, this contrast is often framed as the educated clergy and monastics against an ignorant laity, who seemed more interested in magic and charms than in true religion. Although this rather puerile characterization is nearly ubiquitous in popular sentiment, even serious historians continue to perpetuate it. ${ }^{1}$ The truth of the matter is quite the opposite. It is precisely the modern era, the age of Aufklärung, in which an actual, though far subtler, form of religious elitism begins to emerge. ${ }^{2}$ Whereas no significant difference in religious cult can be found between the educated and the illiterate for most of Christian history ("popular religion" was precisely that-popular), the modern era introduced a distinction between what the masses (oi $\pi \mathrm{O} \lambda \lambda \mathrm{\lambda}$ oí) believe and practice and the more refined and enlightened religion of the "reformed." As Peter Burke notes, in 1500 "popular culture was everyone's culture. . . By 1800, however, in most parts of Europe, the clergy, the nobility, the merchants, the professional men-and their wives-had abandoned popular culture to the lower classes, from whom they were now separated, as never

Jonathan Martin Ciraulo is a doctoral student in systematic theology at the University of Notre Dame, Notre Dame, IN. He adds: I would like to thank Professor Cyril O'Regan for his seminar on Newman in the Spring of 2014 at the University of Notre Dame, which provided the original inspiration and opportunity for this article. Any infelicities or mistakes are, of course, solely my own.

\footnotetext{
${ }^{1}$ As Eamon Duffy comments, "much writing about late medieval and early modern religion has taken it as axiomatic that there was a wide gulf between 'popular' and 'élite' religion. . . . That conviction, crudely expressed in tens of thousands of undergraduate and sixth-form essays, has been absorbed from and is certainly amply reflected even in the work of sophisticated historians." Duffy, The Stripping of the Altars: Traditional Religion in England 1400-1580 (New Haven, CT:Yale University Press, 2005), 2.

${ }^{2}$ This is not to say that the patristic and medieval Church was in anyway classless, or that there did not exist a hierarchy of holiness. There certainly was a built-in system of "different speeds" of Christian commitment, to use Charles Taylor's term. The crucial difference, however, is that the category of sanctity was not the exclusive property of one social class or another (or if it was, as the mendicant orders demonstrate, it was more closely aligned with the poor), whereas "higher religion" in the modern era comes to be equated with civility or polite society. Taylor attempts, admittedly with difficulty, to make the distinction between the medieval and the modern forms of elitism in A Secular Age (Cambridge, MA: Belknap, 2007), 61-211. Hereafter cited:Taylor, A Secular Age.
} 
before, by profound differences in world view." ${ }^{3}$ What this meant for religion was that the older practices of pilgrimages, shrines, martyr cults, and miraculous healings, often pagan in origin, were denigrated in favor of a doctrinally minimal form of Christianity, free of the "gross exaggerations" of popular piety. ${ }^{4}$ To accept this dichotomy would be to validate the claims of a gnostic elite who, while technically belonging to the Church, maintained a rational and respectable Deism congenial to the secular public despite the external cult. Clearly, this double-tiered structure of the educated as contrasted with the uninformed masses can only result in the negation of the Christian faith as a viable option: omnis civitas, vel domus divisa contra se, non stabit. ${ }^{5}$ Thus, to truly justify a religion-in this case Catholicism-one must somehow also justify the practices of its adherents.

One of the most comprehensive responses to this difficulty in the modern era is offered by Blessed John Henry Cardinal Newman. In overcoming his earlier antiCatholic prejudice, Newman made an important theological shift which, when closely examined, demonstrates the crux of his philosophical and theological vision. Owing partly to his own need to justify what he previously considered the superstitious nature of Catholicism as evidenced by the masses of uneducated devotees on the continent, Newman provides an important defense of true Christianity as non-elitist in principle. As this essay will demonstrate, throughout Newman's career as a public intellectual, he provided two interrelated arguments, one epistemological and the other theological, against a rationalistic view of religion that virtually equates intellectual acumen and civility with sanctity. It is Newman who defends "popular Catholicism," not only to justify his own conversion, but also in an attempt to stem the elitist religious tides of the English Enlightenment. For Newman, the "superstition" of Catholicism as found in the least to the most educated is a bulwark against the divisive tendencies in philosophical and political thought. After tracing Newman's treatment of these issues, we will end with a comparison to Augustine's City of God, which likewise proposed that the unity of religious cult and propositional theology, or mythology and philosophy, comprises Christianity as a religion. The value in comparing Augustine and Newman on this point lies in their parallel defenses of Christianity against its detractors. For both Augustine against the pagans and Newman against the rationalizing tendencies of Anglicanism and English Protestantism, the Catholic Church stands as the single institution capable of radically uniting the religion of the masses with a high marker of theological sophistication. In the last instance, then, a mark of primitive Christianity and its modern successor is its "superstitious" nature, though with this typically pejorative word clarified and elevated.

Newman admitted that, during his Anglican period, he was "in principle Anti Catholic," and later felt as a Catholic the necessity of retracting some of his more

\footnotetext{
${ }^{3}$ Peter Burke, Popular Culture in Early Modern Europe (New York: New York University Press, 1978), 270. According to Burke, this "reforming" tendency resulted in both the withdrawal of the upper classes from popular culture and the attempt to civilize the lower classes, and was an attribute of both Protestant and Catholic reformers, though far more of the former than the latter.

${ }^{4}$ It is already possible to see here, in nuce, Karl Marx's eventual criticism of religion as das Opium des Volkes. In many ways it is the logical consequence of this early rejection.

${ }^{5}$ Matthew 12:25, in Biblia Sacra: The Holy Bible in Latin and English (Ex Fontibus, 2009). All citations of the Bible in this essay are taken from this version.
} 
egregious anti-Catholic statements. ${ }^{6}$ Although tracing Newman's own prejudice against Catholicism and its eventual eradication would be a useful project, this essay will highlight only the examples that touch on its present topic: Newman's intellectual development with regard to "superstition" in Christianity, especially as attributed to the Roman Church.Although he later said that "I was very superstitious, and for some time previous to my conversion [when I was fifteen] used constantly to cross myself on going into the dark," ${ }^{7}$ Newman nonetheless considered the superstitious nature of popular Catholicism as a strong count against it. We begin with Newman's trip to Rome in March of 1833.As demonstrated in his journals at the time, Newman was both fascinated and horrified by what he encountered. Concerning the religious state of the Italian Church, Newman found much to admire, especially its history of Apostles and Saints. "But then on the other hand the superstitions;-or rather, what is far worse, the solemn reception of them as an essential part of Christianity. . . Really this is a cruel place." As he says several years later, in his 1836 Via Media of the Anglican Church, the Catholic Church would need a reformation, but this reformation would have less to do with doctrine and be "far more a reform of [its] popular usages and opinions." In short, for Newman, while the Roman Church looked good on paper, in practice it was an ugly sight. Thus, the Via Media considers many of the doctrinal positions of the Roman Church to be aberrations and corruptions; yet more often than not, Newman argues for a doctrinally "Catholic" Church (which necessarily places it close to Roman Catholicism), purified of the abuses and excesses of Romanism. ${ }^{10}$ Before the 1840 s, it seems that the state of Roman Catholicism, real or perceived, simply precluded the possibility of conversion for Newman. He felt a growing attraction to the Roman Church, but perceived a lingering sense of darkness and impurity about her. Thus we find him writing, less than a year apart from one another, first that "When we go into foreign countries, we see superstitions in the Roman Church which shock us; when we read history, we find its spirit of intrigue so rife, so widely spread, that 'jesuitism' has become a byword;" and, later, addressing himself to the Church of England, "Give us more services-more vestments and decorations in worship-give us monasteries. ... Till then, you will have continual defections to Rome." ${ }^{11}$ Although he could not perceive it at the time, what he considered to be most repugnant about the Roman Churchits external cult-he would later consider its greatest strength.

As Ian Ker aptly notes, "The story of John Henry Newman's conversion to Catholicism is not quite the same as the story of his discovery of Catholicism." ${ }^{12} \mathrm{Ker}$ means that Newman's initial draw towards the Catholic Church was intellectual,

\footnotetext{
${ }^{6} \mathrm{JHN}$ to Jemima Newman, Oriel College, Oxford, 4 March 1829, in The Letters and Diaries ofJohn Henry Newman, vol. 2 (London: Nelson; Oxford: Clarendon, 1961), 128. Hereafter cited: JHN, LD. He also makes retractory statements throughout Apologia pro Vita Sua.

${ }^{7}$ Newman, Apologia pro Vita Sua, ed. Ian Ker (New York: Penguin, 2004), 24. Hereafter cited: Newman, Apologia.

${ }^{8}$ JHN, Letter to John Frederic Christie, Rome, 7 March 1833, in $L D$ vol. 3, 240-41.

9 Newman, The Via Media of the Anglican Church, ed. H.D. Weidner (Oxford: Clarendon, 1990), 94-95.

${ }^{10}$ This is seen clearly in the famous Tract 90, in which Newman attempts to interpret the 39 Articles in a "Catholic" manner that excludes the Roman abuses of those doctrines and practices.

${ }^{11}$ Newman qtd. in Ian Ker, Newman: A Biograpby (Clarendon: Oxford, 1988), 188 and 179. Hereafter cited: Ker, Newman.

${ }^{12} \mathrm{Ker}$, Newman's Post-Conversion Discovery of Catholicism," in Newman and Conversion, ed. Ian Ker (Notre Dame, IN: University of Notre Dame Press, 1997), 37-58, 37. Hereafter cited: Ker, "Newman's PostConversion." The larger text is hereafter cited: Ker, Newman and Conversion.
} 
inspired by the writings of the Fathers, ${ }^{13}$ but little influenced by actual encounter with Catholics or familiarity with Catholic life and culture. This discovery of a new world, which Newman accepted with alacrity, is evidenced in his post-conversion defenses of Catholicism, such as Certain Difficulties Felt by Anglicans in Catbolic Teaching (1850) and Lectures on the Present Position of Catbolics in England (1851). In these works, as well as in his novel Loss and Gain ${ }^{14}$ (a thinly veiled autobiography of his own conversion), we find a portrayal of Catholicism as a living, acting organism as opposed to a lifeless, intellectual faith. We will return to Newman's position as found in these works, but for the moment it suffices to note how he portrays anti-Catholic prejudice in England. Although to what extent these remarks represent his own former position is impossible to say, ${ }^{15}$ we can say for certain that Newman shared at least partially in what he later describes about the "Prejudiced Men": "What is our ground of comfort [the Mass], however, will be their ground of accusation against us; for they are sure to go away and report that our worship consists of crossings, bowing, genuflections, incensings, locomotions, and revolvings, all about nothing." ${ }^{16}$ Newman knows, after entering the Church and discovering her way of life, that to a Protestant-and even more so to a liberal one-the rites of the Catholic cult will remain obscured in mystery. ${ }^{17}$ This is because of an irreconcilable difference between a religion of the word and a religion of action. As Ker delineates, for Newman, "A verbal, cerebral religion requires education and intelligence; the Catholic mass, by contrast, is a drama centered on an event that is equally accessible to all the worshippers." ${ }^{18}$ Thus, Newman was initially led by his intellect to a religious sphere in which the intellect would no longer have pride of place (although it would certainly have its place). The original cause for his hesitation, the external, physical, and popular nature of Catholicism, becomes for Newman the defining nature of the truth he was seeking.

\section{EPISTEMOLOGICAL FOUNDATIONS}

Before we can discuss the properly theological aspect of Newman's thought, we must explore the epistemological groundwork that engenders it. The necessity of this prior, philosophical work is clear, since to argue that Christianity is non-rationalistic while conceding that some form of rationalism provides the most accurate epistemology would, at best, be akin to fideism or non-foundationalism. An alternative to the nineteenth-century's bourgeoning, and now largely dominant, process of

\footnotetext{
13 "The Fathers made me a Catholic, and I am not going to kick down the ladder by which I ascended into the Church." Newman, "Letter to Dr. Pusey," in Certain Difficulties Felt by Anglicans in Catbolic Teaching, vol. 2, rev. ed. (1900; repr., New York: Longmans, Green, and Co, 2001), 24. Hereafter cited: Newman, "Letter to Dr. Pusey."

${ }^{14}$ Newman, Certain Difficulties Felt by Anglicans in Catbolic Teaching, vol. 1, rev. ed. (1901; repr., New York: Longmans, Green, and Co., 2001). Hereafter cited: Newman, Difficulties. Newman, Lectures on The Present Position of Catholics in England (New York:The America, 1942). Hereafter cited: Newman, PPCE. Newman, Loss and Gain: The Story of a Convert, rev. ed., (1906; repr., New York: Longmans, Green, and Co., 2001).

${ }^{15}$ Newman does give some indication of his own views when he says, "I say deliberately, and have means of knowing what I say, having once been a Protestant, and being now a Catholic.” Newman, PPCE, 31.

${ }^{16}$ Ibid., 194.

${ }^{17}$ Our definition of liberalism is simply Newman's, as explained in "Note A" of Apologia, 252-62. In brief, liberalism in religion is characterized as being anti-dogmatic in principle and is "the mistake of subjecting to human judgment those revealed doctrines which are in their nature beyond and independent of it [.]" Apologia, 254.

${ }^{18}$ Ker, "Newman's Post-Conversion," 53.
} 
rationalism was required. In short, what was needed was a new anthropology:" $[\mathrm{M}]$ an is not a reasoning animal; he is a seeing, feeling, contemplating, acting animal. He is influenced by what is direct and precise." ${ }^{19}$ A human being is simply not what John Locke thought one was. The person cannot be dreamt up in a laboratory, but must be found in the streets. Thus the epistemology of both the rationalists and the empiricists is an impossibility, and while it may be an impressive philosophical monument, it can never be found in reality.

Although Newman's more immediate interlocutors include the likes of Bishop Joseph Butler and Richard Whately, the most important philosopher behind Newman's writings on faith, reason, and epistemology is the fountainhead of all subsequent English liberalism, John Locke. Thus Locke will function in this essay as a synecdoche, standing in for all of his intellectual progeny and making allowances, mutatis mutandis, for their modified forms of Lockeanism. Although he maintains the conceptual distinction between faith and reason, for Locke, eventually even revelation must be submitted to the prior criterion of reason: "[I]t still belongs to reason to judge of the truth of its being a revelation. ... Indeed, if anything shall be thought revelation which is contrary to the plain principles of reason, and the evident knowledge the mind has of its own clear and distinct ideas; there reason must be hearkened to, as to a matter within its province." ${ }^{20}$ While Locke appears to be simply describing the proper functioning of human cognition, it is clear that the aim of his work is primarily prescriptive. This is most evident in his "principle of proportionality," given its evidentialist presuppositions: according to Locke's criteria of verification, one may only have the same level of confidence, and take the subsequent actions stemming from this confidence, in proportion to the probability of its being true. ${ }^{21}$ The impetus behind this assertion is a political angst and a desire to stem "fanaticism." 22 In light of intra-Christian religious warfare since the Reformation, especially the Thirty Years War, ${ }^{23}$ what can adjudicate between the

\footnotetext{
${ }^{19}$ Newman, An Essay in Aid of a Grammar of Assent (Notre Dame, IN: University of Notre Dame Press, 2001), 90. Hereafter cited: Newman, Grammar.

${ }^{20}$ John Locke, Essay Concerning Human Understanding, ed. Alexander Campbell Fraser, 2 vols (New York: Dover Publications, 1959), 2.4, 18.8. Hereafter cited: Locke, Essay. Locke provides much more nuance than we are able to articulate here. It should be noted that he does affirm that revelation, coming from God, exceeds the abilities of reason. Yet, only reason is able to decide whether a revelation should be considered divine or not. Gotthold Ephraim Lessing goes even further:"Revelation gives nothing to the human species, which the human reason left to itself might not attain." Lessing, "The Education of the Human Race," in Literary and Philosophical Essays, The Harvard Classics, ed. Charles W. Eliot, trans. F.W. Robertson, vol. 32 (1778; repr., New York: P.F. Collier \& Son, 1938), 185.

${ }^{21}$ Nicholas Wolterstorff nicely summarizes this principle: "Having determined the probability, on one's satisfactory evidence, of the proposition in question, one ought to adopt a level of confidence in it which is proportioned to its probability, on that evidence." Wolterstorff, "Locke's Philosophy of Religion," in The Cambridge Companion to Locke, ed. Vere Chappell (Cambridge: Cambridge University Press, 1994), 184.

${ }^{22}$ Taylor provides a helpful set of definitions for key terms in the eighteenth century: "Three kinds of dangerous religion were categorized as 'superstition', 'fanaticism', and 'enthusiasm'. The first designated the enchanted dimension of religion, the rites and cults and practices which partook of magic in their understanding. . . 'Fanaticism' designated the kind of religious certainty that seemed to the agent concerned to licence going well beyond, and even committing gross violations against the order of mutual benefit. While 'enthusiasm' meant the certainty that one heard the voice of God[.]" Taylor, A Secular Age, 239.

${ }^{23}$ In retrospect, it is not difficult to argue, as David Bentley Hart does, that these early modern "wars of religion" can more accurately be described as "the first wars of the modern nation-state, whose principal purpose was to establish the supremacy of secular state authority over every rival power, most especially the power of the church." Hart, Atheist Delusions: The Christian Revolution and Its Fashionable Enemies (New Haven, CT:Yale University Press, 2009), 88.
} 
varying religious claims of authority, whether of Church or of interpretation of Scripture? For Locke, the answer can only be what is universally available, which is found in the totalizing power of "the candle of the Lord," reason. ${ }^{24}$

Reason, however, will not allow one to hold to the particular doctrines of any denomination with much certitude, and never with the degree of certitude required to conduct religious warfare. It is precisely when one holds the tenets of a creed with levels of certitude disproportionate to what reason allows that doctrine leads to fanaticism and extravagance. ${ }^{25}$ In place of zeal for truth and religious assent that could ultimately lead to martyrdom, Locke proposes mutual toleration and a scaling back of personal convictions, or at least the manifestation of those convictions. Religious identity is then reduced to a matter of taste, and is akin to selecting which hat to wear. ${ }^{26}$ If this is true, and as all admit, de gustibus non est disputandum, a secular use of reason must in the end regulate discourse and dissipate fanatic immoderation. However, Locke's theological generosity only extends so far. While it may be a matter of taste to be either a Lutheran or an Anglican, being a Catholic or an atheist is, for him, positively reprehensible. The former cannot be tolerated because their bonds of loyalty extend beyond the bounds of the nation, and the latter because only God can assure adherence to morality. ${ }^{27}$ Even if Catholics should be permitted to believe in their illogical doctrines in private, the very nature of Catholic dogma is such that it subverts reason and corrupts the mind, and is thus inimical to the well-being of the nation. ${ }^{28}$ In the end, what is needed to increase both individual and social well-being is education and "the civilizing process." ${ }^{29}$ The existence of God as "the independent Supreme Being" should be taught to children, but nothing more concerning religion, in order that they not be carried away by superstition. As the children grow, they should be taught more about religion, but without instilling too much curiosity in divine matters, all the while submitting everything to the criterion of what is

${ }^{24}$ Locke, Essay, 2.4, 19.8. Brad S. Gregory follows the trajectory from the Reformers' emphasis on sola scriptura and the intra-Christian debates about scriptural authority to the final decision for sola ratio in his book, The Unintended Reformation: How a Religious Revolution Secularized Society (Cambridge, MA: Belknap, 2012); he does so especially in Chapter 2, "Relativizing Doctrines," 74-128.

${ }^{25}$ When people contradict common sense in this way," and have been ... led into so strange opinions, and extravagant practices in religion, that a considerate man cannot but stand amazed at their follies, and judge them so far from being acceptable to the great and wise God,... he cannot avoid thinking them ridiculous and offensive to a sober good man." Locke, Essay, 2.4, 18.11.

26 "It would be though a hard case, if by a law, now made, all would have to be fined that should wear French hats for the future, and those also who had worn them at any time in the year past. It is the same case to forbid a man to be a Quaker,Anabaptist, Presbyterian, for it is as easy for me not to have had on the hat yesterday, which I then wore, as it is in many cases not to have the same opinions, the same thought, in my head as I had yesterday." Locke, "Toleration B" (1676), qtd. in Elizabeth A. Pritchard, Religion in Public: Locke's Political Theology (Stanford: Stanford University Press, 2014), 24.

${ }_{27}$ "That Church can have no right to be tolerated by the magistrate which is constituted upon such a bottom that all those who enter into it do thereby ipso facto deliver themselves up to the protection and service of another prince. ... Lastly, those are not at all to be tolerated who deny the being of a God. Promises, covenants, and oaths, which are the bonds of human society, can have no hold upon an atheist. The taking away of God, though but even in thought, dissolves all." John Locke, A Letter Concerning Toleration (1689), in The Works of John Locke in Nine Volumes, vol. 5, 12th ed. (London: Rivington, 1824), 46-47, bttp://oll.libertyfund.org/titles/1725. The larger text is hereafter cited: Locke, Works.

${ }^{28}$ For instance, using papal infallibility and transubstantiation as examples, Locke says, "[M]en will disbelieve their own eyes, renounce the evidence of their sense, and give their own experience the lie, rather than admit anything disagreeing with these sacred tenets." Locke, Essay 2.4, 20.10.

${ }^{29}$ For the emergence of the concept of "civility" and "polite society" in early modern Europe, particularly as standing in marked contrast to the "uncivilized masses," see Norbert Elias, The Civilizing Process: Sociogenetic and Psychogenetic Investigations, trans. Edmund Jephcott (Malden, MA: Blackwell, 2000). 


\section{"reasonable." ${ }^{30}$}

In contrast, for Newman religion is not a matter de gustibus, and it is certainly not like putting on a hat. Although Newman agrees with Locke's desire to stem the tide of warfare, religious or otherwise, he does not think that trivializing religious devotion is the solution, even if it were possible. For Newman, modernity as represented by Locke's religious epistemology marks a radical break with realism, if not with reality. According to Newman, Locke-the great empiricist-was not empirical enough. ${ }^{31}$ The genius of An Essay in Aid of a Grammar of Assent is its appeal to a simple examination, as empirical as possible, of how humans actually think. In other words, it strives not to begin with an a priori assumption about how a human sbould think, or even how humans could best think, but with how people actually $d o$ think. After praising Locke's character and thought, Newman comes to the following conclusion: "[Locke] takes a view of the human mind, in relation to inference and assent, which to me seems theoretical and unreal. Reasoning and convictions which I deem natural and legitimate, he apparently would call irrational, enthusiastic, perverse, and immoral." ${ }^{32}$ It comes down to an anthropological crisis: whereas Newman contents himself with how humans are actually found, which includes their impulsivity, lack of critical thought, and tendency to prejudice, Locke "would form men as he thinks they ought to be formed, into something better and higher." ${ }^{33}$ As will be shown, Newman builds this anthropological positivism into the very structure of his theology and his conception of Catholicism. Before we arrive at the theological conclusion, we must explore a few more issues related to his epistemology: the distinction between assent and inference and how he parses the relationship between faith and reason, which will then serve as an entrance into theology. Beginning with "the experience of human life, as it is daily brought before us," Newman contends that instead of abiding by Locke's principle of proportionality, which everyone necessarily contradicts daily, humans act according to principles prior to ratiocination: "Persons influence us, voices melt us, looks subdue us, deeds inflame us. Many a man will live and die upon a dogma: no man will be a martyr for a conclusion." ${ }^{34}$ This points to the important conceptual distinction between inference and assent. ${ }^{35}$ Whereas an inference is made through the use of logic and is inherently abstract, assent is far more basic than logical distinctions, and aims at the concrete. ${ }^{36}$ The mistake that John Locke makes is to assume that everything can be submitted to the process of logical inference.This is not only difficult, but impossible.

\footnotetext{
${ }^{30}$ Locke, Some Thoughts Concerning Education (1692), in Locke, Works, vol. 8, 128-29, paragraph 136. See also 141, paragraph 146, where he critiques the "morality and religions of the world" for their acceptance of customs and rites, which they are willing to die for, without the critical use of reason.

${ }^{31}$ For a brief look at Newman's response to Locke in Grammar, see R.A. Naulty, "Newman's Dispute with Locke," Journal of the History of Philosophy, 11.4 (1973): 453-57; see also Edward P. J. Corbett, "A Comparison of John Locke and John Henry Newman on the Rhetoric of Assent," Rhetoric Review 1, no. 1 (Sept. 1982), 40-49.

${ }^{32}$ Newman, Grammar, 139.

${ }^{33}$ Ibid., 139.

${ }^{34}$ Ibid., 141, 89.

${ }^{35}$ It is beyond the scope of this essay to catalog each nuance in Newman's categories, but we can briefly generalize that notional apprehension is an inference, in that it is conditional and aims at a conclusion; real apprehension is an assent, in that it is unconditional and categorical. Although this essay primarily treats inference and assent, inference is closely related to notional assent; thus, when we use the term "assent," we mean "real assent."

${ }^{36}$ Newman, Grammar, 215.
} 
As in Newman's now-famous example, we all assume that Great Britain is an island, though hardly anyone has sailed around it to verify this claim. We accept on the authority of others a fact that radically orients one's life. We assent without going through the "proper channels" of inference. If Locke followed his own method strictly, he could not agree that he was living on an island until he had circumnavigated it, thereby empirically verifying this supposition.

The primacy of assent before inference necessitates a reviviscence of the Aristotelian emphasis on $\varphi \rho o ́ v \eta \sigma \iota \zeta$, practical wisdom.Although Newman, in reading Aristotle, is consciously performing an act of retrieval from the past, he does not suggest that this retrieved knowledge is dead or that it must be "dug up." The Aristotelian emphasis on practical reason is not a quaint idea from antiquity, but is the way all people, including John Locke, always-already think, and more importantly, act. Life is not about achieving propositional certainty, but "Life is for action. If we insist on proofs for every thing, we shall never come to action: to act you must assume, and that assumption is faith." ${ }^{37}$ Thus, to learn to act well, one must gain $\varphi \rho o ́ v \eta \sigma \iota \zeta$, which is found by imitating others and by practicing virtuous actions. "Instead of trusting logical science, we must trust persons, namely, those who by long acquaintance with their subject have a right to judge." ${ }^{38}$ Newman radically democratizes reason because, for him, it is not the intellectual elite who have an epistemic advantage with regard to "our most natural mode of reasoning," but rather those who skillfully use practical reason, either through natural talent or acquired habit. This is "especially exemplified both in uneducated men, as in men of genius, - in those who know nothing of intellectual aids and rules, and in those who care nothing for them,- in those who are either without or above mental discipline." ${ }^{39}$ To exemplify the ubiquity of practical wisdom, Newman not only accentuates figures such as Napoleon, but peasants as well. For example, conscience is the great internal teacher, and it is "for high and low, young and old, men and women, independently of books, of educated reasoning, of physical knowledge, or of philosophy." ${ }^{\prime 0}$ We will return to the democratization of reason in relation to religious matters, but for the moment we assert that this must be the case, unless we are to categorize the majority of people lacking scientific reasoning as somehow sub-human. ${ }^{41}$ If Newman is not correct about the priority of conscience and action, then we must "take refuge in the intolerable paradox, that the mass of men are created for nothing, and are meant to leave life as they entered it." ${ }^{2}$

\section{THEOLOGY OF SUPERSTITION}

Having surveyed the epistemological groundwork, we can now examine how it applies to Newman's overall theological project. Just as the criteria for judging a moral life has shifted away from the cognitive and ultimately elitist sphere of higher

\footnotetext{
${ }^{37}$ Ibid., 91.

${ }^{38}$ Ibid., 268-69.

${ }^{39}$ Ibid., 260-61.

${ }^{40}$ Ibid., 304.

${ }^{41}$ Thomas Aquinas likewise recognized that felicitas cannot be dependent on knowledge of material things, for two main reasons: "[I]t is hardly possible for anyone in this world to understand all material things: and thus no one, or very few, could reach to perfect felicity. ... Further it is unreasonable that only the few of any species attain to the end of the species." Summa Theologica I, q. 88, a. 2, co.

${ }^{42}$ Newman, Grammar, 91.
} 
education or civilité and toward what is readily available to all-namely, $\varphi \rho o ́ v \eta \sigma \iota \varsigma$ - so the requisite for Christian identity is transferred from notional to real assent, or from reason to faith. ${ }^{43}$ The interplay between faith and reason in Newman is a complicated issue, one that is not easily resolved. At first blush, it may seem as if Newman is an anti-foundationalist who likens Christian faith to an incommensurable Wittgenstinian language-game. ${ }^{44}$ While it is true that reason does not function as an arbiter between differing sets of belief - and it is uncertian what does ${ }^{45}$ - this does not mean that reason and faith are not mutually interprenetrating. As one commentator tersely summarizes, for Newman "it is no longer reason suspended from the faith it is supposed to be supporting; it is faith supporting reason, and reason, thus supported, supporting faith." ${ }^{6}$ Newman's first major attempts to distinguish faith from reason come from his Oxford University Sermons, in which he formulates ideas that are later clarified in the Grammar. In terms of real versus notional assent, Newman essentially couples faith with the former and reason with the latter. ${ }^{47}$ Faith is primary for Christian identity, and rests upon testimony and authority rather than argument and proof. ${ }^{48}$ Again, like real assent, it is oriented toward action and is independent of rational verification. This does not mean that faith is only an act of the will: it is an intellectual act, but not a rationalistic one. ${ }^{49}$ The practical importance of these distinctions is a redefinition of what actually constitutes a Christian. As Newman sees it, the influence of modern, secular philosophy upon Christianity has led to the reduction of faith to reason and to the assumption that the exemplary Christian is the educated one. For Newman, this not only contradicts the testimony of Christian holiness as found in the saints, ${ }^{50}$ but also tends towards an elitism that is in stark contrast with scripture: sed quae stulta sunt mundi elegit Deus ut confundat sapientes; ${ }^{51}$ nos stulti propter Christum..$^{52}$

As Newman treats the democratization of reason, so he does religion. Again, this treatment appears first in the University Sermons and reaches its apogee in the Grammar. He says in Sermon 13:

\footnotetext{
${ }^{43}$ For a more complete survey of Newman's discussion of faith and reason, with special attention to how these views altered from the Oxford University Sermons to the Grammar, see Chapter 6 in Ker, Newman, 257-315. See also Thomas J. Norris, "Faith," in The Cambridge Companion to John Henry Newman, eds. Ian Ker and Terrence Merrigan (Cambridge: Cambridge University Press, 2009), 73-97.

${ }^{44}$ For a comparison of Newman and Wittgenstein, see Cyril Barrett, S.J.,"Newman and Wittgenstein on the Rationality of Religious Belief," in Ker, Newman and Conversion, 89-99. Hereafter cited:Barrett,"Newman."

${ }^{45}$ In Oxford University Sermon 12, Newman attempts to suggest that love can regulate faith, and keep it from bigotry. While he may not be entirely successful even in this regard, he at least does not suggest that love also adjudicates between faith traditions or between faith and secularism. Nevertheless, whatever would stymie the deformation of Christianity would have to be, for Newman, found in the internal resources of the faith, and not extra muros. Newman, Sermon 12, "Love the Safeguard of Faith against Superstition," in Fifteen Sermons Preached Before the University of Oxford, rev. ed. (1909; repr., London: Longmans, Green, and Co., 2001), 222-50. Hereafter cited: Newman, OUS.

${ }^{46}$ Barrett, "Newman," 99.

47 "Faith is a principle of action, and action does not allow time for minute and finished investigations. . . [investigations of reason,] whatever be their character and consequences, they do not answer the needs of daily life." Newman, OUS, 188.

48 "Faith is independent of processes of Reason. . . It simply accepts testimony." Newman, OUS, 180.

49 "Right Faith is the faith of a right mind. Faith is an intellectual act; right Faith is an intellectual act, done in a certain moral disposition." Newman, OUS, 239.

${ }^{50}$ It is worth noting that Newman was editing the Lives of the English Saints shortly before his conversion, and could thus observe the diverse nature of sanctity exemplified therein.

${ }^{51} 1$ Corinthians 1:27.

521 Corinthians $4: 10$.
} 
Nothing would be more theoretical and unreal than to suppose that true Faith cannot exist except when moulded upon a Creed, and based upon Evidence. . . [to assert this is] to maintain that every child, every peasant, must be a theologian. Faith cannot exist without grounds or without an object; but it does not follow that all who have faith should recognize, and be able to state what they believe, and why. ${ }^{53}$

Being a Christian does not necessitate being a theologian: this is a seemingly simple statement, one that should be superfluous to utter, yet is denied consistently in practice. This simple assertion goes against the grain of modernity, which insists on verification and personal apprehension of all beliefs, and which would ultimately necessitate either an absolutely minimal amount of doctrine (as in Deism or Unitarianism) or an advanced theological education for all of the laity. In the Grammar, this logical progression leads to the key distinction between religion and theology. In short, religion is a real, personal assent to the object of devotion, namely God, whereas theology is a notional and scientific apprehension. ${ }^{54}$ Newman does not divorce religion from theology, but rather states that although the former is a prerequisite for being a Christian, the latter should be undertaken in accordance with one's abilities. Theology is necessary to guard religious devotion, but just as one need not understand the intricacies of English grammar to speak the language, so one need not know the subtleties of the hypostatic union to pray to Christ as God. ${ }^{55}$

As is repeatedly mentioned throughout the Grammar, Newman concedes that there are countless Christians, in particular Catholics, who do not notionally comprehend the dogmas to which they adhere. To justify this state of affairs is a major burden of the text. We could say that Newman provides an epistemic preferential option for the poor. Thus, even though "the greater number of [theological propositions] are more or less unintelligible to the ordinary Catholic, as law-books to the private citizen," the peasant is bound by them just as much as the academic. ${ }^{56}$ The reality is that nobody, including the most erudite, entirely comprehends the mystery of faith, and thus everyone needs the "supplement" of faith in the infallible Church. ${ }^{57}$ Each Catholic, then, implicitly believes in all that the Church teaches by making an act of real assent to the truth of revelation, regardless of how much he or she can actually propositionally understand said doctrines. Newman provides the example of a child. A young child cannot grasp propositions that exceed her intellectual ability, and thus if Christianity were to be based on an intellectual criterion, children, and likewise the mentally handicapped, would be rightly excluded from the Church. The de facto practice of the Church, namely infant baptism, suggests otherwise. Just as Newman demonstrated an epistemological positivism in his analysis of how people think, so he does with the Church: he refers to the actual life and cult of the Church. Though the state of undereducated and superstitious Christians was an

\footnotetext{
${ }^{53}$ Newman, OUS, 254.

${ }^{54}$ Newman, Grammar, 62.

${ }^{55}$ Ibid., 109.

${ }^{56}$ Ibid., 128

57 "[E]very Catholic, according to his intellectual capacity, supplements the shortcomings of his knowledge without blunting his real assent to what is elementary, and takes upon himself from the first the whole truth of revelation, progressing from one apprehension of it to another according to his opportunities of doing so.” Ibid., 131.
} 
embarrassment for liberals in the nineteenth century, it is Newman's boast. ${ }^{58}$ As Newman is wont to emphasize, particularity is a mark of heresy, and liberal Christianity has made itself the religion of the few. True Christianity, on the other hand, "alone has a definite message addressed to all mankind. . . and is found in all parts of the world, in all climates, among all races, in all ranks of society, under every degree of civilization, from barbarism to the highest cultivation of mind."59 The Enlightenment created a system of value based upon education, a system that, though inimical to Christianity, has since been imperceptibly adopted by many Christians. Newman's diagnosis is that a Christianity that has, consciously or not, adopted the Enlightenment model as normative has betrayed its own raison d'être; it has been "cleaned up" to the point of unrecognizability. In two important lectures from Difficulties, Newman addresses this issue explicitly. Lectures 8 and 9 respectively examine the social and the religious state of historically Catholic countries. As Newman phrases the problematic thought of liberal Christians, "Those countries, you say, which have retained Catholicism are notoriously behind the age; they have not kept up with the march of civilization; they are ignorant, and, in a measure, barbarous." ${ }^{60}$ Newman notes the prejudice that leads to this view; yet even if it were true that Catholic countries are "behind the age," this denigration only demonstrates that the English were asking the wrong question. If Anglicans and Protestants, then and now, see a lack of temporal prosperity as a sign against Catholicism, it only proves that they have lost sight of Christianity's hallmark in the first place. Granting the Protestant assumptions about the life of Catholics, he says that although Catholics may be superstitious and profane, Christianity is real to these people, whereas in England it is purely notional. ${ }^{61}$ Again, there must be a separation between sanctity and refined manners, between holiness and education. While the Catholic Church may often be found without the latter, it possesses an abundance of the former. The mark of holiness, which is a category that entirely transcends social class, has perdured in the Church since the beginning.

\section{AUGUSTINE'S CITY OF GOD}

Cardinal Newman is often fittingly compared with St.Augustine, in no small part

\footnotetext{
${ }^{58}$ We by no means intend to give the impression that Newman is anti-intellectual or opposed to theological education; he is, after all, the author of The Idea of a University and a resolute pedagogue. Nevertheless, even in this text, with its exaltation of higher education, Newman is highly wary of the "Religion of Reason" and illustrates the neutrality of education vis-à-vis holiness: the characteristics of the cultivated intellect "partly assist and partly distort the development of the Catholic. They may subserve the education of a St. Francis de Sales or a Cardinal Pole; they may be the limits of the contemplation of a Shaftesbury or a Gibbon. Basil and Julian were fellow-students at the schools of Athens; and one became the Saint and Doctor of the Church, the other her scoffing and relentless foe." Newman, The Idea of $a$ University, rev. ed. (1907; repr., New York: Longmans, Green, and Co., 2001), 211.

${ }_{59}$ Newman, Grammar, 334. He says the same at the very end of the Grammar, which is a notable placement:True Christianity is found "in the most cultivated, in the rudest races and intellects, in all classes of society[.]" 378 .

${ }^{60}$ Newman, Lecture 8, "The Social State of Catholic Countries No Prejudice to the Sanctity of the Church," in Newman, Difficulties, 230.

${ }_{61}$ "And thus, even one who has been a bad Catholic may have a hope in his death, to which the most virtuous of Protestants, nay my brethren, the most correct and most thoughtful among yourselves, however able, or learned, or sagacious-if you have lived not by faith but by private judgment-are necessarily strangers." Newman, Lecture 9, "The Religious State of Catholic Countries No Prejudice to the Sanctity of the Church," in Difficulties, 294-95.
} 
because the two stand as bookends of Christian Europe.$^{62}$ With regard to the issue at hand, Augustine did for the fifth century what Newman did for the nineteenth. Augustine's City of God responded to the pagan counterreaction against the growing Christianization of the Empire and was precipitated by the sack of Rome, while Newman stood at what seems to be the twilight of that robust Christian identity in Western Europe. The chief difference between Augustine's and Newman's interventions is that while the former demonstrates the superiority of Christianity to classical paganism because of its logical coherence, the latter does not point to logic, but to Christianity's assimilation of the human condition. Although the task of comparing two figures separated by such a substantial cultural and temporal gap is daunting, it is worth the cost of generalizing to elucidate what both Augustine and Newman considered to be the genius of Christian faith in light of its cultured despisers, whether of the pagan or the liberal variety. There are two major similarities to be explored: first, the accusations made against Christianity as the cause for social disaster, and second, an emphasis on what we will here call Christianity's "non-twotiered system."

Newman himself notes the formal similarity between anti-Christian sentiment within the Roman Empire and anti-Catholicism in England: Such was the disgust felt towards our predecessors in primitive times. . as a set of mean, sordid, despicable fanatics, as monsters reveling in blood and impurity. Such also is the deep prejudice now existing against the Church among Protestants." ${ }^{63}$ According to Augustine, ${ }^{64}$ this pagan prejudice against Christianity - which culminates in the accusation of destroying the Roman Empire-is not only unjust, but does not correspond with the facts of history, even those of pagan historians themselves. ${ }^{65}$ Nevertheless, this final accusation was a continuation and coda of the scapegoat mechanism used against Christians as evidenced from Diocletian and Julian the Apostate onward. Augustine, noting this tendency, sardonically quotes what he says was a popular proverb: "No rain? Blame the Christians!" 66 The response to this accusation occupies roughly the first half of City of God. In Books One through Four, Augustine entertains the pagan question: what has happened to cause such suffering at the hands of the Visigoths in 410 ? In the end, Augustine offers a few half-hearted suggestions as to the "why" of human suffering, but he refuses to answer the question fully because he deems it to be the wrong question. The question that the pagans should have asked was not one of theodicy, but about which gods produce moral devotees and can truly offer eternal

\footnotetext{
${ }^{62}$ The most common point of comparison is their two great Christian autobiographies of conversion: the Confessions and the Apologia. Overall, while Newman often shows greater affinity for the Greek Fathers (as his well-known heroic portrayal of Athanasius demonstrates), his indebtedness to Augustine is considerable. This becomes most conspicuous in his Lectures on the Doctrine of Justification.

${ }^{63}$ Newman, Grammar, 205. See also Chapter 6 of Newman's An Essay on the Development of Christian Doctrine, (Notre Dame, IN: University of Notre Dame Press, 1989), to which we will return. Hereafter cited: Newman, Development.

${ }^{64}$ Due to the limitations of this essay, we will not examine whether Augustine's own perceptions of paganism correspond with reality, and will simply assume that his argument is sound.

${ }^{65}$ Thus, Augustine's main sources of history are all pagan (e.g., Livy and Cicero). He uses the pagans' own sources against them, showing that a clear-headed analysis of history demonstrates the barbarity of Rome long before the arrival of Christianity.

${ }^{66}$ Augustine, The City of God (De civitate Dei), 2 vols., trans. William Babcock (New York: New City, 2012/2013), 2.3, 39. All quotations of The City of God are taken from this edition. Hereafter cited: Augustine, Civ.
} 
life, the topic to which he devotes Books 5 through 10. The pagan solution was to return to the gods of antiquity and scorn the new God of Christianity, who evidently had no power to protect the Empire. Although Augustine attempts to assuage this frustration, he cannot answer it adequately because it is the wrong question, stemming from wrong first principles. A new question needed to be asked.

Newman likewise entertains the Protestant critique that Catholicism does not provide temporal benefits, and in fact leads only to social ruin. This is also an assertion based on the wrong question. While historical and sociological evidence could be furnished to refute it, even to begin to do so would incorrectly validate that question. ${ }^{67}$ Religion is not sought in order to gain admittance to gentlemen's clubs or to improve government and infrastructure.$^{68}$ As Newman attempts to redirect the question, he, like Augustine, finds that society is hoping to return to a previous golden age, a time before things went awry. Just as in Augustine's case, this meant a call, actualized or not, to return to the former gods, so Locke and his liberal legacy issued a call to return to a rational, non-dogmatic, and primarily moral religion. Just as Rome fell because of Christianity, so the Thirty Years War and political disharmony in England among various religious sects were seen to be caused by religious fanaticism as ineluctably found in Romanism. The Roman Church, with its perceived pandering to the lower classes, ostensibly led to a desire for martyrdom, a crusading mentality, and everything fundamentally inimical to social cohesion. Thus emerges the myth of a "return" to primitive Christianity, not in the Anglican or Evangelical sense, but in the Lockean. "Original" Christianity is essentially everything that, according to Locke, a good moral agent would hope for: a paucity of dogma, professions of kindness and tolerance, and assent only to rationally verifiable truths, which are, of course, minimal. As we will show shortly, Newman uses the arguments of the liberal English historian, Edward Gibbon, against this hypothesis. Gibbon, in his monumental History of the Decline and Fall of the Roman Empire (1776-89), asserts that Christianity, from its very inception, is secretive, subversive, mysterious, and "a religion which is considered to burden and enslave the mind by its requisitions, to address itself to the weak-minded and ignorant, to be supported by sophistry and imposture, and to contradict reason and exalt mere irrational faith." ${ }^{69}$ This characterization bears a striking resemblance to how Roman Catholicism was popularly characterized in England. Much as Augustine demonstrated in City of God by employing the work of pagan historians, a "return" to notions of an idyllic past would be a return to something much different than Locke imagined.The notion of a "purified" Christianity only serves to reveal that the core of Christianity has been materially rejected by these parties, even if it would take time for this to become formally manifest.

\footnotetext{
${ }^{67}$ As Max Weber suggests, perhaps there is some correlation between Protestantism and economic growth. Max Weber, Protestant Ethic and the Spirit of Capitalism (New York: Routledge, 2001).

${ }^{68}$ The corruption of religion into civilité is exemplified by the future Cistercian monk Thomas Merton's experience with his school chaplain in 1929: "[H] is religious teaching consisted mostly in more or less vague ethical remarks, an obscure mixture of ideals of English gentlemanliness and his favorite notions of personal hygiene. ... [For him] charity meant good-sportsmanship, cricket, the decent thing, wearing the right kind of clothes, using the proper spoon[.]" Merton, The Seven Storey Mountain:An Autobiography of Faith (San Diego: Harcourt Brace 1998), 81.

${ }^{69}$ Newman, Development, 246.

${ }^{70}$ For an analysis of Augustine's thinking on the lie versus truth-telling, see Paul J. Griffiths, Lying: An Augustinian Theology of Duplicity (Grand Rapids, MI: Brazos, 2004). Augustine actually calls the pagan temples "the lodgings of lies." Augustine, Civ. 2.26.
} 
A more theologically substantive point of comparison between Augustine and Newman is their proposal of Christianity as being inherently opposed to the creation of a two-tiered system in religion. This also embodies Augustine's continual rebuttal to paganism: it functions as a deliberately self-deceptive system characterized by its linguistic preference, namely, the lie. ${ }^{70}$ The theme of the lie is pervasive throughout the Augustinian corpus and exemplifies an important characteristic of the earthly city as separated from God. From the very beginning of City of God, the earthly city is typified as a society of intentional self-duplicity: not only does it deceive others, but it knowingly deceives itself. Self-hatred is made politically manifest in civil war, ${ }^{71}$ but makes an even more malicious appearance in the religious sphere. Poets and philosophers know that the gods either do not exist or that they cannot be rightly adored due to their lack of morals. ${ }^{72}$ Therefore, a double discourse in pagan thought emerges: philosophy and theology/myth, which are not only incompatible, but positively contradictory. The greatest Roman thinkers, such as Cicero, Seneca, and Varro, as well as lesser figures, such as Balbus, are all radically implicated in this dichotomy. While they loudly denounce the gods in philosophical discourse, they do not dare to even whisper these truths in public. The reason that they worship the gods they know do not exist-which is the height of self-duplicity-is that "there are many things that are true which it is not useful for the common people to know, and many also which, even if false, it is expedient for the populace to think true." ${ }^{73}$ The masses must be deceived by the superstitious rites in order to maintain social cohesion. Seneca, for example, "still worshiped what he condemned, did what he denounced, and adored what he accused... he acted out the lie in such a way that the people presumed him to be acting out the truth." ${ }^{74}$

Augustine's portrayal of the uniqueness of Christianity in the City of God includes not only its non-duplicitous nature, but its maintenance of the fundamental cohesion between worship and belief, between cult and philosophy-or to put it in Newman's terms, between religion and theology. Despite being historical and particular, Christianity is a religion intended for all peoples of all times and is by nature inclusive. Thus, while Christianity is the "true philosophy", its genius does not lie in in esoteric teaching. Book 10, which is Augustine's majestic blending of the theologies of sacrifice, Christology, ecclesiology, and Eucharistic theology, presents the splendor of Christ not as "the exclusive property of any one people but as the common property of all peoples." 75 The dichotomy between philosophy and religious cult in paganism necessarily leads the multitude to seek out theurgists. As he candidly admits, "the vast majority have no liking for philosophy," which implies to the Platonist that the vast majority cannot live the highest, most virtuous kind of life. ${ }^{76}$ In stark contrast to this social division, "[t]he great multitude for whose sake Christ came

\footnotetext{
${ }^{71}$ Augustine, Civ. 3.31.

${ }^{72}$ This theme begins as early as Civ. 1.3, but is so prevalent in Books 1-10 that citation of all instances would be excessive.

${ }^{73}$ Augustine, Civ. 4.31, 139. Another example is found in Civ. 7.34: Numa's explanation of the religious rites is quickly destroyed in order for the truth to remain hidden.

${ }^{74}$ Augustine, Civ. 6.10, 204

${ }^{75}$ Augustine, Civ. 10.32, 344.

${ }^{76}$ Augustine, Civ. 10.27, 336. One need only think of the structure of the Republic, in which only a few are suitably educated to pursue a life of philosophy, while the majority are either of the producing or the guardian class.
} 
to liberate them from the domination of demons pays no attention to all this," because Christ promises eternal life and thus "the world is flocking to him." All now have access to the highest kind of life, from "any little old Christian woman" to the most erudite philosopher, because what Christianity requires is not intellectual acumen, but personal conversion and incorporation into the ecclesial body. ${ }^{78}$ It is worth noting that while Augustine is highly critical of pagan religious practices, he never claims that, for instance, the Delphic oracles did not actually prognosticate the future, or that certain miraculous occurrences did not issue from the hands of the gods, because he is not denouncing the possibility of supernatural phenomena or the validity of religious cult as a whole. ${ }^{79}$ Though transformed from the inside out, similar phenomena are also integral to Christianity. Christian religious practices, from the martyr cult to the Eucharistic liturgy, are not peripheral or reserved for the unenlightened, but are integral to Christian identity. ${ }^{80}$ As Augustine sees the matter, the Church bridges the yawning chasm between popular devotion and refined thinking that exists in paganism. ${ }^{81}$ While pagan philosophers could only engage in civic religion in a knowingly duplicitous manner, Christian theologians not only can participate in Christian cult, but must in order to merit the title. Augustine says of Christians who prefer Plato to Christ: "They fear that sharing a name with the vulgar crowd will cheapen the elite status of those who wear the philosopher's cloak, a status that is the more inflated the more it is restricted to the few." ${ }^{2}$

If, as Augustine argued, Christianity resolves the problem of dichotomy between external cult and theological discourse, and thus between the majority of simple believers and the educated elite, Newman sees the tides of the Enlightenment as pulling the two apart once again. This happens through the liberal Protestant reduction of religion to a minimal collection of intellectual propositions, even though the mass of Christians, Protestant or Catholic, are doctrinally maximal, involved in religious rituals, and highly zealous. In this way, "true" Christianity is removed from the public sphere and reserved for those with a liberal education and training in the bourgeois mores of the day. Likewise, liberal Christianity demonstrates a noted antipathy toward externalism and locates Christian identity solely in the mind. However, perhaps having more anthropological optimism than their pagan forbearers, the Enlightenment did attempt to overcome this social division by initiating everyone into the elite sphere. Education then became the new missionary impulse. ${ }^{83}$ For example, John Toland's Christianity Not Mysterious (1696), following

${ }^{77}$ Ibid., 10.27, 337.

${ }^{78}$ Ibid., 10.11, 318.

${ }^{79}$ His answer, which is not wholly satisfactory, is that these events truly do occur, but through the work of demons rather than gods, in order to ensnare their worshippers in error and sin. Ibid., 18.18, 296-298.

${ }^{80}$ For a helpful overview of Augustine's relationship to Christian cult, see F. van der Meer, Augustine the Bishop: The Life and Work of a Father of the Church, trans. Brian Battershaw and G.R. Lamb (New York: Sheed and Ward, 1961), particularly Part 4, "Popular Piety," 471-560.

${ }^{81}$ The gap between philosophy and myth in paganism is also a major theme in Hans Urs von Balthasar's The Glory of the Lord: A Theological Aesthetics. Volume IV:The Realm of Metaphysics in Antiquity (San Francisco: Ignatius, 1989): "[T]he way forward from here leads only through the Christian revelation, which is uniquely able to accomplish the otherwise unattainable synthesis between poetry (myth) and philosophy." 195

${ }^{82}$ Augustine, Civ. 13.16, 81 .

${ }^{83}$ Newman said that one of the tenets of liberalism was the following: "Virtue is the child of knowledge, and vice of ignorance. Therefore, e.g. education, periodical literature, railroad travelling, ventilation, drainage, and the arts of life, when fully carried out, serve to make a population moral and happy." Apologia, 261. 
Locke closely, proposes a rational manner of reformulating Christianity to explain scriptural passages that suggest a mysterious or doctrinal interpretation, which all Christians are liable to misunderstand. ${ }^{84}$ On the contrary, for Newman, Christianity is essentially mysterious. This, however, is not something that must be taught to the masses, but is already apprehended. As he demonstrates throughout On Consulting the Faithful in Matters of Doctrine (1859/1871), the laity, educated or not, have a sensus fidei. Though there is a legitimate division between the ecclesia docens and the ecclesia discens, they are "put together, as one twofold testimony, illustrating each other, and never to be divided." ${ }^{55}$ The sensus fidei is not the same as a notional apprehension of doctrinal formulations, but " $[t]$ he body of the faithful is one of the witnesses to the fact of the tradition of revealed doctrine... their consensus through Christendom is the voice of the Infallible Church." ${ }^{86}$ There can then be no strict division between what the theologian teaches and the populace believes, because both assent to the whole of the faith; although the former may intellectually comprehend a greater portion of the teaching, the latter both assents to and witnesses the same truth. There is a double attestation to the one truth, with the liturgical cult both witnessing and affirming the theological explanation. ${ }^{87}$

\section{CONCLUSION}

By way of a conclusion, we will clarify our usage of "superstition." For Newman, it is not a univocal concept. ${ }^{88}$ There are two basic definitions of superstition in Christianity that we have been employing: first, an actual corruption of Christianity, which no one, including Newman, would find admirable; second, superstition as used indiscriminately to describe traditional forms of Christian practice. This latter is only used ironically by Newman.According to this latter usage, as employed by both liberal and evangelical Christianity, religion that is characterized primarily by facts, and not ideas, by cult and not by proposition, is necessarily "superstitious." If this is so, Newman welcomes the appellation. For Newman, this type of superstition is the sine qua non of Christianity, as found in history and in the modern Catholic Church, and thus it is to be emphasized as the great scandalum crucis. Especially as found in Development, the defining characteristic of Christianity is that it will be accused of such superstition by the world. Just as the ancient world found it, so it will be found now:

${ }^{84}$ John Toland, Christianity Not Mysterious: Text, Associated Works, and Critical Essays. Ed. Philip McGuinness, Alan Harrison, and Richard Kearney (Dublin: Lilliput, 1997).

${ }^{85}$ Newman, On Consulting the Faithful in Matters of Doctrine, ed. John Coulson (New York: Sheed \& Ward, 1961), 71. Hereafter cited: Newman, Consulting. For a recent exploration of the concept of sensus fide $i$, which, significantly, draws on Newman, see the International Theological Commission, Sensus Fidei in the Life of the Church (2014): bttp://www.vatican.va/roman_curia/congregations/cfaith/ cti_documents/rc_cti_20140610_sensus-fidei_en.btml.

${ }^{86}$ Newman, Consulting, 63.

${ }^{87}$ "And it [Catholic Marian teaching] is also exemplified, as I verily believe, not only in formal and distinctive Confessions, not only in books intended for the educated class, but also in the personal religion of the Catholic populations." Newman, "Letter to Dr. Pusey," 94.

${ }^{88}$ In OUS 12, Newman considers superstition as relative to the community that is performing the act: "Here we may lay it down as a principle, that what is superstition in Jew or Christian is not necessarily such in heathen; or what in Christian is not in Jew. . sacrifices of blood were not necessarily superstitious in heathen; they would be most superstitious and profane in Christians." Newman, OUS, 242-43. 
It is a natural enemy to governments external to itself; it is intolerant and engrossing, and tends to a new modelling of society; it breaks laws, it divides families. It is a gross superstition; it is charged with the foulest crimes; it is despised by the intellect of the day; it is frightful to the imagination of the many. And there is but one communion such. ${ }^{89}$

As previously mentioned, this is Gibbon's characterization of early Christianity, and is for Newman the essential marker of a non-corrupt form of Christianity. Corruption as defined in the Development includes a non-preservation of type, and if the type from its inception is this dark, mysterious, and popular religion, then a Christianity that is "refined" and primarily concerned with moral uprightness is paradoxically a corruption. By attempting to remove the supposedly "corrupt" elements of Christianity, liberal religion has consequently corrupted it. We thus find Newman frustrating any attempt, however well-intentioned, to exonerate Christianity from the accusation of superstition and excess. He insists that the early Roman descriptions of Christianity, such as those of Pliny ("bad and excessive superstition") and Tacitus ("deadly superstition") were correct and that they were under no illusions. ${ }^{90}$ Though it is shocking that Newman, as a Catholic, revels in what formerly horrified him as an Anglican, this insistence on the nature of Christianity as popular and "superstitious" illustrates that Newman has discovered the great error of his age, to which Christian faith must ever be antithetical: the corruption of revelation by secular reason. This sanitized form of Christianity is not simply a deviation; it is a counterfeit.

With respect to the first definition of superstition in Christianity, such as an actual transformation of the cult of Mary into Mariolatry or the use of a relic as a talisman, Newman notes that this is also a corruption of Christian faith. ${ }^{11}$ Yet if the two options are between a corruption into actual superstition on the one hand and a corruption into rationalism on the other, Newman unhesitatingly opts for the former. In fact, Newman saw the divide very early, and chose his side. In a sermon he wrote as an Anglican entitled "The Religion of the Day," Newman says that the "world's religion" of the day "has taken the brighter side of the Gospel, its tidings of comfort, its precepts of love; all darker, deeper views of man's condition and prospects being comparatively forgotten. This is the religion natural to a civilized age." ${ }^{92}$ In contrast,

[i]t would be a gain to this country, were it vastly more superstitious, more bigoted, more gloomy, more fierce in its religion, than at present it shows itself to be. Not, of course, that I think the tempers of mind herein implied desirable, which would be an evident absurdity; but I think them infinitely more desirable and more promising than a heathen obduracy, and a cold, self-sufficient, self-wise tranquility. ${ }^{93}$

\footnotetext{
${ }^{89}$ Newman, Development, 208.

${ }^{90}$ Ibid., 210.

${ }^{91}$ Newman also thinks that the ascription of Mariolatry to Catholics is typically prejudicial, and that a true corruption into Mariolatry is much more rare than assumed.Also, the devotion to Mary and the Saints does not "interrupt" worship of Christ, but actually protects it:"[I]f we take a survey at least of Europe, we shall find that it is not those religious communions which are characterized by devotion towards the Blessed Virgin that have ceased to adore her Eternal Son, but those very bodies. . . which have renounced devotion to her." Newman, Development, 426.

${ }_{92}^{2}$ Newman, Sermon 1.24, "The Religion of the Day," in Parochial and Plain Sermons (San Francisco: Ignatius, 1997), 199.

${ }_{93}$ Ibid., 205. He also quotes from this sermon in the Apologia (60). See also OUS 11.27 for a similar comment.
} 
In the final analysis, actual superstition is preferable to a cold rationalism because while both may be corruptions, the former is at least still human: "Taking human nature as it is, we may surely concede a little superstition, as not the worst of evils, if it be the price of making sure of faith." ${ }^{94}$ True Christian faith, then, will always appear to a civilized age as superstitious, and will in fact be tempted toward actual superstition; this is because a religion of facts, as opposed to a religion of ideas, makes such a vivid impression upon its adherents that the sensible world seems to be only thinly veiling the spiritual. This "excess," which disregards the guidelines of either empiricism or rationalism, will always be, in the eyes of a society profoundly averse to superstition, the domain of the fool.

Newman, "Preface to the Third Edition," in The Via Media of the Anglican Church, vol. 1, bttp://www.newmanreaderorg/works/viamedia/volume 1/preface3.html, 10-57, 42 . 


\title{
READING THE BIBLE AND THE DOCTRINAL QUESTION IN ARIANS OF THE FOURTH CENTURY
}

\author{
KOTA KANNO
}

\begin{abstract}
The first scientific work by John Henry Newman, Arians of the Fourth Century, should not be read simply as a patristic historiography; Newman engages with theoretical problems in this work. This essay attempts to explain the theory behind Arians with particular regard to the problematic relationship between Scripture and doctrinal expression in the Church. It will demonstrate the confluence of Newman's thought on this point with the theological reflection of Vincent Holzer, who discusses this problem in the context of German theology in the twentieth century.This article was originally published in French in Études Newmaniennes no. 29 (2013).
\end{abstract}

Tt is often said that Scripture is the fundamental matrix of theology; the nuances of various theological positions notwithstanding, this acknowledgment has often been repeated in the course of twentieth-century thought. Given that John Henry Cardinal Newman is often considered a theological pioneer, it seems worthwhile to examine how he read Scripture at the time of his doctrinal research.

To this end, it is easy at first glance to outline an answer, thanks to his $\mathbf{1 8 5 8}$ lecture entitled "Literature" in The Idea of a University. ${ }^{1}$ In this lecture, Newman examines the nature of the Bible by way of distinguishing it from literature. Of course, he acknowledges that literary analysis provides one approach to the Bible, but he reminds us of the scientific nature of the Bible, that is, the nature that demonstrates its immutable, eternal reality: "In proportion, then, as Scripture excludes the personal colouring of its writers, and rises into the region of pure and mere inspiration, when it ceases in any sense to be the writing of man..., then it comes to belong to Science, not Literature." In this way, the Gospels and the book of Genesis specifically constitute a scientific nature, this immutable reality.

This is what suggests to us Newman's position: biblical reading with a view toward doctrinal research-that is, not literary, but scientific, if we use Newman's term-must be carried out in a definitive manner. In this way, historical ambiguities will be done away with, and the immutable truth will emerge as a scriptural fact.

But it is necessary to pose the following question: is the logic of Newman's reading really at work when it enters into practical theology? We know that in Newman's work there are two poles: theoretical, "notional" understanding, and practical, "real" understanding. These two categories are tied to one another, but a tension subsists in their relationship. This essay will demonstrate this lively tension

Kota Kanno, O.P., is currently a doctoral student at the Institut Catholique de Paris, Theologicum (Department of Theology). He is a Dominican friar of the Province of Canada (Vicariate of Japan).

${ }^{1}$ John Henry Newman, "Literature," The Idea of a University 2.2, rev. ed. (1907; repr., London: Longman, 2001), 268-94. Hereafter cited: Newman, "Literature."

2 Newman, "Literature," 289-90. 
with regard to the question of reading the Bible using a doctrinal approach. In so doing, it presents a link between what Newman found in the course of his theological practice and one of the results of current research.

This essay will make its approach with reference to Arians of the Fourth Century. ${ }^{3}$

Before entering directly into the subject, a clarification is necessary: why the choice of this book to study the doctrinal question? Is this book not dedicated rather to patristic and historical research?

This is a relevant question. Indeed, later studies that mention this book are primarily motivated by an interest in patristic studies. Nevertheless, it is possible to contemplate Arians in this context for the following reason: the problem of heresies entails a doctrinal question. Newman wanted to explain the soundness of doctrinal choices in reading the Council Fathers. Such an explanation requires a reflection on the relationship between Scripture and doctrinal language. In fact, he approaches this topic in the book. Thus, while taking into consideration the nature of Arians, we can approach the problem of reading Scripture in light of the doctrinal question.

Now, let us deal with this question.

\section{READING THE BIBLE FOR THE SAKE OF RESEARCH ON THE TRINITARIAN MYSTERY}

The purpose in treating Arians has been clarified. Firstly, this essay does not seek to clarify Newman's thought with regard to patristic studies. Its purpose is to show how, in this book, Newman presents the link between his reading of the Bible and his doctrinal thought.

Indeed, in Arians, we observe two intrisically connected points: the question of biblical reading, analyzed through an examination of literary style, and that of the Alexandrian Fathers' manner of thinking and teaching. Ultimately, this school of thought leads to the adoption of the doctrinal statement. In fact, the expressions of the Alexandrian school become like doctrinal statements by passing through two distinct phases: first, the expressions of this school are submitted to public debate with the other schools. Second, the Council of Bishops approves the expressions as a norm of the faith, which must be implemented throughout the Church.Thus, here, it is not enough to see the relevance of the Alexandrian expression; the theological practice of this school is an integral part of the formation of doctrine in the entire Church. ${ }^{4}$ This observation by Newman is important in understanding the connection between the nature of the Bible and doctrinal statements.

Newman's editorial purpose in Arians is not difficult to outline: by means of his patristic research, he wants to affirm the legitimacy of the Alexandrian School's thought so that the formulation can be reconciled with Trinitarian doctrine. The difficulty he encounters rests on the explanation of historical fact toward this justification.

\footnotetext{
${ }^{3}$ Newman, Arians of the Fourth Century (1833), with an introduction by Rowan Williams. Notre Dame, IN: University of Notre Dame Press), 2001. Hereafter cited: Newman, Arians.

${ }^{4}$ This is my own summary of the argument of Arians. Regarding doctrinal formation, see in particular Section 1 of Chapter 2, On the Principle of the Formation and Imposition of Creeds," 133-50; concerning the question of the authority of Church in determining answers to doctrinal questions, see p.148-49.
} 
The question concerning biblical reading reintroduces precisely this difficulty. The Bible is not meant to answer technical theological questions, yet it is the source of faith. In looking at the Bible with regard to the doctrinal question, we are at an impasse, at least at first. Newman expresses this in a fairly paradoxical statement. He first indicates the statute of the source of faith to illustrate the Bible: "[T]he Bible, though various in its parts, forms a whole, grounded on a few distinct doctrinal principles discernible throughout it." In another passage, we read that we cannot draw conclusions straight out of the Bible. ${ }^{6}$ What does it mean? Where does that leave us?

In answer, the author first focuses his observation on a school from antiquity: the Alexandrian school. In the first part of the book, which deals with the theoretical question, Newman primarily discusses two major trends: the school of Antioch and that of Alexandria. Through an analysis using theological methodology from the Alexandrian school, Newman attempts to summarize the main points in an intelligible manner to make the connection between Scripture and doctrinal formula. I will not enter into unnecessary details on this subject, but the question of the economic method is central to his observation. To express it, he analyzes the Alexandrian methodology, allegorical interpretation. Because Scripture uses allegorical figures, biblical reading requires interpretation. The economic method in the Alexandrian school corresponds at once to the inherent style of Scripture itself and at the same time to an intrinsic connection to the philosophical language of the era, notably Platonism. In this way the prerequisite condition is given.

Newman does not, however, neglect to note a negative aspect of this methodology, namely, that Scripture does not answer all demands, especially for doctrinal formulation. This negative point also clarifies the relationship between biblical reading and dogmatic formulation as a limited one, thus validating the regulating role entrusted to the Church.

Firstly, according to Newman, the Bible is not meant to set forth doctrines by means of theological formulae. Newman underscores the Bible's purpose: the first purpose of Scripture is religious, meaning that it applies itself to religious sentiment; its objective is not philosophical. This explanation gives us a glimpse of the mentality of the era - the Romantic character of Newman's nineteenth century-but I want to point out instead that such an understanding of the Bible's purpose serves to underscore the primacy of mystery in the face of intellectual speculation where matters of faith are concerned. Indeed, Newman himself highlights this primacy.

But, even if we allow for the primacy of the mystery of the faith with the pious sentiment proper to it, the faithful are right to ask him to reveal his system of thought. This for good reason: the faithful have entered into debates with philosophers and heretics, and the ideal apostolic era is long over. Because the piety of the Apostles governed the first community, it did not experience doctrinal conflict; such is the image that Newman offers. However, once discussion of faith enters into a public

\footnotetext{
${ }^{5}$ Newman, Arians, 58.

6 "Nor. . is an assent to the text of Scripture sufficient for the purposes of Christian fellowship." Ibid., 146.

${ }^{7}$ He notes "the incomprehensibility of the Divine Essence." Ibid., 34. The term "incomprehensible" is used at least one other time: see p. 229.
} 
domain, it is useful to establish its teaching in a convincing manner. That is the first condition of theological thought.

However, there is a requirement more difficult to satisfy. The discussion of faith does not remain simply an argument ad extra. It must simultaneously elicit a response within the community of faith and attempt to explain, as far as possible, a theological notion in the context of the whole mystery of the faith, so as to form a system. Concerning this need, Newman observes the inverse attitude of the heretics, the Arians.

The mere words "Father and Son", "birth", "origin", \&c, were all that they postulated of revealed authority for their argument; they professed to do all the rest for themselves. The meaning of these terms in their context, the illustration which they afford to each other, and, much more, the divine doctrine considered as one undivided message, variously exhibited and dispersed in the various parts of Scripture ...8

We understand thus the task of biblical reading toward a doctrinal discussion: the interpretation of the Bible attempts to synthesize the notion of this or that doctrinal content across books of Scripture in considering the allegorical and typological nature of the Bible. To do this, dialogue with other philosophical systems is expected, but it is always necessary to observe the primacy of the mystery of faith and the indivisible character of each doctrinal notion. The philosophical system is organic. The coherence of the system does not primarily aim for philosophical precision. But it aims to indicate the whole of the mystery of faith as the Bible evokes it, even in ways not immediately clear to readers. Such is the reflection of Newman concerning the relationship between biblical reading and theological thought based on his observation of the Alexandrian school.

A qualification is necessary. However subtle, this theological process, such as Newman presented it, is filtered through our reflection, and is therefore a human process. Newman notes in some passages the limit of this Alexandrian school method. How did the Fathers manage to rectify their errors? To answer this, it is insufficient to end with theological school methods, which are fallible. This is why Newman presented his thought in Chapter Two, "The Teaching of the Ante-Nicene Church in its Relation to the Arian Heresy-Section I. On the Principle of the Formation and Imposition of Creeds:" "An investigation of the principle upon which the formation and imposition of creeds rests." This passage is not a simple anecdotal insertion; it shows the role of clergymen in doctrinal conflicts. Thus, the theological formulae must pass through the ecclesial process to ensure an orthodox faith in the community. The conflicts of schools that the author has analyzed in the first part find a solution in ecclesial regulation. Here, the doctrinal statement legitimately becomes the dogmatic statement.As to the question of structure, it is at the heart of the second part of Arians. Thus, the two parts of this book are logically bound together. I carefully note this role before passing to another reading, namely, the question of the concrete link between biblical reading and doctrine. This is in fact the theme of

\footnotetext{
${ }^{8}$ Ibid., 220-21.

${ }^{9}$ Ibid., 133.
} 
Arians; it concerns the Trinitarian question, notably the status of the Son. The analysis of this reading, however, exceeds the frame of my argument.

\section{THE NOTION OF "PLASTICITY” AS A LINK BETWEEN DOGMA AND GOSPEL IN THE WORK OF VINCENT HOLZER: A COMPARISON OF TWO THEOLOGIANS}

This essay now turns to a short reading from contemporary theology with a view to a comparison. The question of the relationship between biblical reading and doctrinal formulation is one of the current subjects with which fundamental theology is concerned. In fact, we can refer to a recent article on this subject by Vincent Holzer, "The Revival of the Dogmatic Principle in Contemporary Theology: The Status and Posterity of a 'Science' of the 'Development of Dogma' (Dogmenentwicklung)." ${ }^{10}$ One of the subjects rigorously treated in it is the question of biblical reading, notably observations taken from critical historical exegesis and the status of dogmatic formulas. Holzer begins by showing the dilemma between the plurality of Scripture and the unity of the faith in citing Ernst Käsemann: "The New Testament canon, as such, is not the basis for the unity of the Church. As such, meaning in its state of fact available to historians, it establishes the plurality of confessions of faith." ${ }^{11}$ He finds that the assertion of this exegete is only "a 'variation' of questions on the relationship between dogma and Gospel." ${ }^{12}$ As we have seen, Newman was obliged to confront the same subject.

On this subject, the problem as Vincent Holzer attempts to resolve it could be formulated thus: recognizing both the discontinuity between dogmatic formulas and the diversity of New Testament Christologies, how can we explain the logical continuity to which dogmatic languages make claim with regard to the extant New Testament?

To respond to this question, he offers the term "plasticity," a term borrowed from philosophical interpretation-specifically, that of Hegel: "The 'plasticity' is indeed coextensive to universality, in the particular mode of multiplicity and mobility, and not of univocity. ${ }^{13}$ Holzer applies this notion to the term bomoousios as a question of "the introduction of philosophical and juridical vocabulary in the field of Christology." He considers that the term "plasticity" is "better suited to account for the internal plurality of the expression of this confession of faith [.]" ${ }^{14}$ If the apostolic message (the paradosis) can be qualified as "plastic," this plastic character would be understood as "that which has the power to give shape." ${ }^{5}$ He asserts that "the dogmatic formula could. . . demonstrate the degree of plasticity of the Christian message." ${ }^{16}$ Thus, the diversity of the paradosis and dogmatic statements are not opposed to one another, even if there is always tension between the two.

\footnotetext{
${ }^{10}$ Vincent Holzer, "Le renouvellement du 'principe dogmatique' en théologie contemporaine - statut et postérité d'une 'science' du 'développement du dogme' (Dogmentwicklung)," Recherches de Science Religieuse 94, no. 1 (2006), 99-128. This theological hermeneutics article treats theologians in history from Thomas Aquinas to H.G. Gadamer.

${ }^{11}$ Ibid., 101.

${ }^{12}$ Ibid., 101

${ }^{13}$ Ibid., 104.

${ }^{14}$ Ibid., 104.

${ }^{15}$ Ibid., 105.

${ }^{16}$ Ibid., 105.
} 
I do not, of course, claim that Newman's thought in Arians is identical to Vincent Holzer's thesis on the link between the paradosis or even the mystery of the faith, such as Scripture transmits to us, and dogmatic formulas. Their manner of understanding Scripture is not the same. Yet the clear convergence between the two theologians in this regard cannot be denied: Newman does not use the term "plasticity, but he recognizes the tension between Scripture and the doctrinal statement. To articulate this connection, in the same manner that Vincent Holzer adopts the term "plasticity, Newman uncovers the economical method. Beginning with the allegorical style of Scripture, the economic method enables us to formulate the doctrinal statement by borrowing from the philosophical language of this era. Is there not in the theological approach of Vincent Holzer and Newman more than a coincidental confluence of thought?

\section{CONCLUSION}

It is clear that for Newman, reading the Bible does not limit itself to the doctrinal question; his reading extends to multiple areas of discourse. Even for the limited question on the doctrinal point, the case of Arians is only an example. In measuring these limits, by way of conclusion, two courses of study can be proposed.

The first course concerns the importance of the axis of fundamental theology for reading Newman's works. Fundamental theology concerns itself with the question of foundation, the principles of theological thought. It is certain that, in general, his works do not have such a goal; nevertheless, in each work, Newman clearly indicates his interest in understanding the principles of this or that problem.

The case of Arians is a notable example. When Newman wrote the Apologia pro Vita Sua, he underscored that, in the course of his study of Arianism, he was interested in the "philosophy" of the Alexandrian Fathers: "The broad philosophy of Clement and Origen carried me away; the philosophy not the theological doctrine; and I have drawn out some features of it in my volume [.]" ${ }^{17}$ What is this philosophy? The author follows with:"These were based on the mystical or sacramental principle, and spoke of the various Economies or Dispensations of the Eternal." ${ }^{18}$

This explanation of the author clarifies the meaning of the term "philosophy": what interests Newman is not primarily the doctrinal discourse on the Trinity, but rather the manner in which the Fathers conceived the mystery and their manner of reasoning. It is for this reason that Newman dedicated a considerable portion of his work to an explanation of the economical method. This is what we call his epistemological interest, or the character of the fundamental theology in his works. As we have just seen, this "epistemological" explanation is tied to the question of biblical reading and doctrinal formulation.

In Arians, reading the Bible demonstrates a divergence in relation to what Newman explains in The Idea of a University. The economic method is intimately tied to literary reading, which does not lay claim to the positivity of this or that passage. Yet this reading truly rejoins the theological question as well as the doctrinal

${ }^{17}$ Newman, Apologia pro Vita Sua rev. ed. (1908; repr., London: Longman, 2001), 26.

${ }^{18}$ Ibid., 27. 
question. We can, therefore, observe a tension between theory and practice in Newman.

When we reflect on the question of epistemology in theology, we have a tendency to analyze only two theoretical works: The Idea of a University and the Grammar of Assent. It is true that these books treat this question. But Newman reveals that at the time of his reflections in Arians, he was also thinking of the epistemological question, and he expounds it. We assess Arians as a book of practical theology; we observe that at times there is a great tension between thought in the course of practice and theory.

A second course can be approached in the opposite manner, that is, in terms of the need to throw into relief Newman's status in the wider history of fundamental theology. Vincent Holzer's article demonstrates well an affinity between German discussions and Newman's practice. Even if Newman's influence has not been direct, it is important to reconsider his place in the history of theology, notably that of the nineteenth century. In doing this, Vincent Holzer's title is significant in itself: he writes of the "science" of the "Development of Dogma." Do not these two notions-the question of the scientific character of theology and the notion of the development of dogma-show the value of Newman's thought? 


\title{
THE PROPHETIC NEWMAN
}

\author{
BRAD S. GREGORY
}

Jobn Henry Newman was a discerning critic of the dominant social values and cultural features of England in the Victorian era that revolved around the sovereign self. Insofar as many of these features-individuals as their own masters, wealth and celebrity, the arbitrariness of answers about faith and meaning, and the character of bigher education in the absence of theology-also characterize American society and culture in the early twenty-first century, Newman's critique of bis own time and society also applies to ours. This essay was first delivered as the 2014 Newman Legacy Lecture, sponsored by the National Institute for Newman Studies, at Duquesne University, Pittsburgh, Pennsylvania, on April 3, 2014.

I remember how struck I was in graduate school when a fellow student, a modern European historian of exceptional learning and ability, told me: "Cardinal Newman saved my life." He explained that Newman had led him back to the Catholicism in which he had been raised and which he had cast off when he began, in high school, to read modern German philosophy and to become what he then thought was "sophisticated." Over the years, others have mentioned to me Newman's profound influence on them. Whence Newman's power? Why does he remain such an arresting thinker for so many people today? Part of the answer, it seems, may lie in the extent to which much of what he wrote has proven to be prophetic.

Newman might be considered prophetic in a number of ways. Perhaps the most obvious is one that many scholars have analyzed: namely, the intra-ecclesial impact on Catholic theology of his argument about the development of doctrine, and of the questions he raised about the laity's role in the Church, both of which influenced the Second Vatican Council. Newman's philosophical explication of the relationship between faith and reason in his Grammar of Assent, too, prefigured aspects of the thought of the later Ludwig Wittgenstein, Hans-Georg Gadamer, and Alasdair MacIntyre in breaking with post-Enlightenment rationalism. ${ }^{1}$ Interesting and important as these influences are, however, Newman was also prophetic in a different, broader sense.

This essay considers John Henry Newman as a social and cultural critic of some of the dominant features of modern Western society. Its chief assertion is that Newman observed, with uncanny clarity, the "first principles" (as he often called them) that animated the English and greater European society in the Victorian era, as

Brad S. Gregory is Professor of History and Dorothy G. Griffin Collegiate Chair at the University of Notre Dame. He is the author of Salvation at Stake: Christian Martyrdom in Early Modern Europe (1999) and The Unintended Reformation: How a Religious Revolution Secularized Society (2012).

${ }^{1}$ David B. Burrell, "Newman in Retrospect," in The Cambridge Companion to Jobn Henry Newman, ed. Ian Ker and Terrence Merrigan (Cambridge: Cambridge University Press, 2009), 255-74. 
well as the cultural priorities and behavioral trends that issued from those principles. He insightfully grasped the underlying assumptions held and acted on by many men and women in mainstream society across England's conspicuous class divisions. Perceiving these principles allowed him to explain a wide range of behaviors with reference to a common commitment. These first principles were, in Newman's estimation, antithetical to Catholic Christianity and therefore, after his conversion in 1845, antithetical to truth, despite the fact that their proponents embraced and promoted them as true. Newman's assessment of the society and culture of his own day after his conversion, then, represents a sharp contrast not only between Roman Catholicism and his former Anglicanism or Protestantism, but also between Catholicism and the wider culture-including Catholics whose de facto allegiances lay more with society's animating principles than with the principles of their own Church. Newman's fundamental conceptualization of modern society is agonistic in ways that repeatedly echo the biblical opposition between the Gospel and the world: "There is but one real Antagonist of the world, and that is the faith of Catholics," he wrote in $1849 .^{2}$ However, it is also tailored to dramatic changes in the nineteenthcentury cultural milieu through which he lived during his long life.

The first principles that Newman discerned as already dominant in midnineteenth-century Britain remain pervasively presupposed, politically protected, and culturally reinforced at every turn in Western societies in the early twenty-first century. Newman observed with acuity the most advanced, industrializing, urbanizing society of his own day-the England in which he lived-and the direction in which it was trending. Western Europeans and North Americans today, especially in the United States, are still moving along the same fundamental trajectory, guided by the same basic principles Newman grasped, albeit within a dramatically altered technological milieu and built (man-made) environment. Those principles have now spread throughout the world especially through the influence of the United States; hence, Newman's insights have proven as relevant in our time as they were in his own. Recognizing this helps to account for the abiding appeal and applicability of Newman's thought a century and a quarter after his death. Many times, in reading Newman, one is startled by a sense that he seems to be describing our world as well as his.

So much by way of introduction to Newman's prophetic observations. Newman's diagnosis of modernity, which proved prophetic with respect to postmodernity, hinges on the centrality of the sovereign individual exercising his or her own will and employing his or her reason in whatever ways he or she pleases. This essay will first discuss this basic notion and then consider four different manifestations of it in Newman's thought.

Newman discerned that the stark contrast between this individualism and the Christianity he internalized so deeply was the key to understanding the tectonic changes through which he was living. He came to see categories such as "the

\footnotetext{
${ }^{2}$ John Henry Newman, "Saintliness the Standard of Christian Principle," in Discourses Addressed to Mixed Congregations (1849; repr., London: Longmans, Green, and Co., 1913), 89-110, 103. Hereafter cited: Newman, "Saintliness." References to the larger text are hereafter cited: Discourses.
} 
principle of private judgment" and "the principle of liberalism"3 — understood initially in narrower, theological contexts-as informing a much wider swath of modern English life. He saw at work an extension of principles that had at first been implicit in the Protestant Reformation, but which by the nineteenth century had been made explicit and had come to influence culture and society much more broadly. In other words, in nineteenth-century Britain, it was not simply that Presbyterians, Methodists, and various sects of dissenting Protestants claimed the right to interpret scripture for themselves, but also that the right to private judgment had been generalized and was being applied outside of exegetical and religious contexts. This right was an expandable, protean principle, applicable to much more than biblical interpretation. Liberalism, too, Newman saw as having begun in England in one form, but it had changed over time and gained a wider compass with unanticipated effects. As he put it in his autobiography, "the Liberalism which gives a colour to society now, is very different from that character of thought which bore the name thirty or forty years ago. Now it is scarcely a party; it is the educated lay world." What began with the Romantic literary journal established in $1822^{5}$ later became the appellation of a theological party ${ }^{6}$; this transformation in turn proved, according to Newman, "dangerous as opening the door to evils which it did not itself either anticipate or comprehend," eventually including the broadest transformation of liberalism into "that deep, plausible scepticism. . the development of human reason, as practically exercised by the natural man." ${ }^{7}$ These remarks reflect Newman's observation that the emphasis on individual autonomy corroded traditional institutions, customs, values, and faith. This principle was promoted in the name of "freedom" and "progress," as articulated, for example, by Newman's paradigmatic and influential contemporary, John Stuart Mill. ${ }^{8}$

The individual self seeking to fulfill his or her own desires, whatever they happen

\footnotetext{
${ }^{3}$ For the most extensive treatments of these principles in Newman's works, see, for liberalism, "The Difficulties of Latitudinarianism," in Certain Difficulties Felt By Anglicans in Catbolic Teaching (1850; repr., London: Longmans, Green, and Co., 1901), 126-41; and "Note A: On Page 116: On Liberalism" in Newman, Apologia pro Sua Vita, ed. David J. DeLaura (1864/1886; repr., New York and London: W. W. Norton, 1968), 491-502. Hereafter cited: Newman, "Note A." References to the larger text are hereafter cited: Newman, Apologia. For private judgment, see two essays written prior to his conversion but published as parts of collections only later, "On the Abuse of Private Judgment," in The Via Media of the Anglican Cburch (1883; repr., London: Longmans, Green, and Co., 1901), 145-67, and "Private Judgment," in Essays Critical and Historical (1871; repr., Longmans, Green, and Co., 1907), 336-74, as well as "Faith and Private Judgment," in Newman, Discourses, 192-213.

${ }^{4}$ Newman, Apologia, 200.

${ }^{5}$ Leigh Hunt, George Gordon Byron Baron Byron, Percy Bysshe Shelley, and William Hazlitt, The Liberal: Verse and Prose from the South, vol. 1 (London: John Hunt, 1822).

${ }^{6} \mathrm{With}$ an opposition that went back to his pre-Tractarian days, Newman understood theological liberals (or "latitudinarians") as those who rejected the notion of definitive, revealed truth in matters of Christian dogma, which opened the door to doctrinal relativism. In his note on liberalism at the end of his Apologia, he explained the matter thus: "Liberty of thought is in itself a good; but it gives an opening to false liberty. Now by Liberalism I mean false liberty of thought, or the exercise of thought upon matters, in which, from the constitution of the human mind, thought cannot be brought to any successful issue, and therefore is out of place. Among such matters are first principles of whatever kind; and of these the most sacred and momentous are especially to be reckoned the truths of Revelation. Liberalism then is the mistake of subjecting to human judgment those revealed doctrines which are in their nature beyond and independent of it, and of claiming to determine on intrinsic grounds the truth and value of propositions which rest for their reception simply on the external authority of the Divine Word." Newman, "Note A," 493.

${ }^{7}$ Newman, Apologia, 200. See also The Liberal.

${ }^{8}$ John Stuart Mill, On Liberty (London: Longman, Roberts \& Green, 1859), rev. ed., On Liberty and Other Essays, ed. John Gray (Oxford: Oxford University Press, 1998).
} 
to be, is no less characteristic of the United States in the early twenty-first century than it was of Britain in the mid-nineteenth. To be sure, much has changed between then and there and now and here. Yet American institutions, laws, and dominant cultural norms have moved in the same direction, along the same lines, and in a manner consistent with what Newman saw. The preferential self-determination of individuals has become more pervasive than it was in Victorian Britain, which remained an acutely stratified class society with an established Anglican Church, both of which constituted part of the frame of reference within which Newman worked and wrote. Even in in Newman's time, the United States lacked such institutional constraints on individualism, the emphasis on which was already more evident than in Britain: the United States never had an established church and had instead institutionalized, as it were, the principle of private judgment in religious matters in the First Amendment to the Constitution. This was one of the features of American culture that so struck Tocqueville when he visited the United States in 1831; Emerson touted it iconically a decade later in his essay, "Self-Reliance." To the extent that the sort of autonomy and self-determination it implies is incompatible with Catholic claims about human dependence on God, divine revelation, and the authority of the Church's teaching for human life, it is incompatible with Catholicism. Newman saw this clearly in his own time and place; it is no less true in ours, but its implications and valences are different, because the context for American Catholics in the early twenty-first century differs so much from that of English Catholics in the nineteenth, whether before or after the restoration of the Roman Catholic episcopate in 1850 .

Let us follow four different ways in which Newman saw expressions of a commitment to the autonomous, sovereign self as the animating first principle of modernity. In each case, his observations remain applicable today. This essay will draw on only a few passages from his Discourses Addressed to Mixed Congregations (1849) and Idea of a University (1852), although these could also be augmented with reference to many other relevant passages in Newman's published works, to say nothing of his correspondence. The four manifestations of the sovereign self are the following: the idea that individual human beings are their own masters and live for themselves; that wealth and celebrity are idolatrous substitutes for persons who do not have God at the center of their lives; that the assertions about faith, meaning, and purpose given by the sovereign self are arbitrary; and, finally, that modern higher education is fragmented and dominated by the utilitarian pursuit of the satisfaction of human desires in the absence of any coherent theological framework.

Let us begin with the idea that human beings are their own masters and live for themselves. In "God's Will the End of Life," the sixth of the Discourses, Newman contrasts what ought to be the pursuit of any Christian's life-doing God's will in imitation of Christ-with what he discerns as the principle guiding the actions and ambitions of most of his fellow citizens in England in the late 1840s. His description could serve well as an account of what Charles Taylor calls "exclusive humanism" in his book, $A$ Secular Age: namely, human life lived without reference to God or any sort

\footnotetext{
${ }^{9}$ Alexis de Tocqueville, Democracy in America, ed. J. P. Mayer, trans. George Lawrence, 2 vols. (1835/1840; repr., New York: HarperCollins, 2000); Ralph Waldo Emerson, "Self-Reliance," rev. ed., in Essays and Lectures, ed. Joel Porte (1841; repr., New York: Library of America, 1983), 259-82.
} 
of transcendence, considered as an end in itself within the "immanent frame" of the world..$^{10}$ In response to the question, "Why were you sent into the world?" Newman offers his characterization of the de facto, widespread answer: "The world professes to supply all that we need, as if we were sent into it for the sake of being sent here, and for nothing beyond the sending.... Every man is doing his own will here, seeking his own pleasure, pursuing his own ends, and that is why he was brought into existence." 11

As Newman emphasizes, the obvious contrast is with Christ, who came to do the will of his Father and who bids Christians to do likewise insofar as they follow him. Despite overwhelmingly identifying as Christians of one denomination or another, Newman's English contemporaries had other priorities, whether they went "abroad in the streets" to make direct observations or " $\mathrm{t}[\mathrm{ook}] \mathrm{up}$ one of those daily prints" and read about the same frenetic activity:

The ways are thronged, carriage-way and pavement; multitudes are hurrying to and fro, each on his own errand,... [They] have come forth into the public concourse, to see and be seen, for amusement or for display, or on the excuse of business. The carriages of the wealthy mingle with the slow wains laden with provisions or merchandise,... The streets are lined with shops, open and gay, inviting customers[.] $]^{12}$

Despite dramatic differences in technology and environment, how different are these phenomena from what we observe today? If we replace carriages with cars and wains with trucks and add suburban shopping malls to urban shops, one might be describing the downtown of a large American city or a suburban center in 2014. Moreover, the range of global information, advertisements, commercial prospects, and curiosities instantly accessible online today dwarfs what was accessible to Newman in the newspapers around 1850. Nonetheless, he conveys the same sense of overwhelmed bewilderment at its sheer scope:

[L]ook down the columns of advertisements, and you will see the catalogue of pursuits, projects, aims, anxieties, amusements, indulgences which occupy the mind of man. ... You will read of the money market, and the provision market, and the market for metals; of the state of trade, the call for manufactures, news of ships arrived in port, of accidents at sea, of exports and imports, of gains and losses, of frauds and their detection. ${ }^{13}$

What is the telos of these preoccupations, what is it all for? Newman registers his exasperation:"O this curious, restless, clamorous, panting being, which we call life!and is there to be no end to all this? Is there no object in it? It never has an end, it is forsooth its own object!" ${ }^{14}$ In other words, human life within the immanent frame neither sees nor seeks an end beyond itself-then or now.

From here Newman moves on to a deeper, more focused characterization of the animating principle, the underlying commitment that explains this human bustle.This

\footnotetext{
${ }^{10}$ Charles Taylor, $A$ Secular Age (Cambridge: Belknap, 2007).

${ }^{11}$ Newman, "God's Will the End of Life," in Discourses, 104-23, 105.

${ }^{12}$ Ibid., 105-06.

${ }^{13}$ Ibid., 106-07.

${ }^{14}$ Ibid., 107.
} 
endeavor "to penetrate into the hearts, and to reach the ideas and the feelings of those who constitute it," ${ }^{15}$ was insightful then and makes clear Newman's prescience in its abiding applicability:

[Y] ou will find them all to be living for the sake of living; they one and all seem to tell you, "We are our own centre, our own end." Why are they toiling? why are they scheming? for what are they living? "We live to please ourselves; life is worthless except we have our own way; we are not sent here at all, but we find ourselves here, and we are but slaves unless we can think what we will, believe what we will, love what we will, hate what we will, do what we will. We detest interference on the part of God or man. We do not bargain to be rich or to be great; but we do bargain, whether rich or poor, high or low, to live for ourselves, to live for the lust of the moment, or, according to the doctrine of the hour, thinking of the future and the unseen just as much or as little as we please." 16

It is difficult to imagine a more straightforward summary of the dominant present-day American ideology, as it reflects the refusal to accept any direction or guidance except on one's own terms and the desire to be the monarchical master of one's own existence. "Don't tread on me." "Mind your own business." "Who are you to tell me what to do?"The institutionalized individualism of American society today embodies what Newman discerned about the ethos of modernity. The counter-missiological notion of just "find[ing] ourselves here" points toward Martin Heidegger's Geworfenbeit ("thrownness") ${ }^{17}$ — "we are not sent here at all," but find ourselves cast, thrown, dropped into existence, in which we endeavor to do whatever we will. Christian Smith has recently identified the promotion and assumption behind this individual autonomy as the unacknowledged but pervasive "sacred project of American sociology." 18 According to Newman, living for oneself, by one's own standards, according to one's own will, and in defiance of any "outside interference" is by definition to reject the end that should order the priorities and actions of Christian life, that is, to follow God's will before our own. In this regard, Newman and Friedrich Nietzsche perceived the same phenomenon, yet evaluated it in antithetical ways: what Newman lamented, Nietzsche celebrated. ${ }^{19}$ Nonetheless, both saw more clearly than most nineteenth-century thinkers the antithetical character of the relationship between Christianity and the sovereign modern self. Whether rejected or

\footnotetext{
${ }^{15}$ Ibid., 107.

${ }^{16}$ Ibid., 108.

${ }^{17}$ The notion of Geworfenbeit plays a central role in Heidegger's existential anthropology of human beings as Dasein in his most influential work, Being and Time, the German original of which appeared in 1927. See Martin Heidegger, Being and Time, trans. Joan Stambaugh (Albany, NY: State University of New York Press, 1996).

${ }^{18}$ Christian Smith, The Sacred Project of American Sociology (New York: Oxford University Press, 2014). "American sociology as a collective enterprise is at heart committed to the visionary project of realizing the emancipation, equality, and moral affirmation of all buman beings as autonomous, self-directing, individual agents (who should be) out to live their lives as they personally so desire, by constructing their own favored identities, entering and exiting relationships as they choose, and equally enjoying the gratification of experiential, material, and bodily pleasures" (7-8, italics in original). Hereafter cited: Smith, Sacred Project.

${ }^{19}$ The incompatibility between Christianity and human autonomy of the sort criticized by Newman is a theme that runs through multiple works in Nietzsche's oeuvre; see, for example, among his later works, Friedrich Nietzsche, Götzen-Dämmerung, oder ie man mit dem Hammer pbilosopbiert (1889), in Nietzsche Werke: Kritische Gesamtausgabe (1889), ed. Giorgio Colli and Mazzino Montinari, Part 6, vol. 3 (Berlin:Walter de Gruyter, 1969). Hereafter cited: Nietzsche, Götzen-Dämmerung.
} 
affirmed, it is a neo-Protagorean idea that man is the measure of all things-each self is the imagined master of his or her own universe.

The second of the four expressions of the sovereign self concerns wealth and celebrity (or what Newman calls "notoriety") ${ }^{20}$ as forms of idolatry. In "Saintliness the Standard of Christian Principle," Newman writes insightfully about the rationality of human actions, understood as intelligible behaviors that issue from the basic commitments of men and women. Notwithstanding claims to the contrary, people believe in something:

Man, a being endued with reason, cannot. . . live altogether at random; he is obliged in some sense to live on principle, to live by rule, to profess a view of life, to have an aim, to set up a standard. . . He must, by the necessity of his nature, look up to something; and he creates, if he cannot discover, an object for his veneration. He teaches himself, or is taught by his neighbor, falsehoods, if he is not taught truth from above; he makes to himself idols, if he knows not of the Eternal God and His Saints. ${ }^{21}$

Appealing to the tradition of common-sense Lockean empiricism, to which he adheres in some respects, Newman invites his listeners (and readers) to discern for themselves to what they and their contemporaries are devoted, what they prioritize, toward what their reason is directed:

Look around, my brethren, and answer for yourselves. Contemplate the objects of this people's praise, survey their standards, ponder their ideas and judgment, and then tell me whether it is not most evident, from their very notion of the desirable and the excellent, that greatness, and goodness, and sanctity, and sublimity, and truth are unknown to them; and that they not only do not pursue, but do not even admire, those high attributes of the Divine Nature. This is what I am insisting on, not what they actually do or what they are, but what they revere, what they adore, what their gods are. ${ }^{22}$

What this basic exercise in attentive observation discloses, Newman contends, is the extent to which an idolatry of wealth pervaded English society in the later 1840s:

Their god is mammon; I do not mean to say that all seek to be wealthy, but that all bow down before wealth. Wealth is that to which the multitude of men pay an instinctive homage. They measure happiness by wealth; and by wealth they measure respectability. Numbers, I say, there are who never dream that they shall ever be rich themselves, but who still at the sight of wealth feel an involuntary reverence and awe, just as if a rich man must be a good man. . . [T]heirs is a disinterested homage, it is a homage resulting from an honest, genuine, hearty admiration of wealth for its own sake, such as that pure love which holy men feel for the Maker of all; it is a homage resulting from a profound faith in wealth, from the intimate sentiment of their hearts, that, however a man may look, ... though he may be ignorant, or diseased, or feeble-minded, though he have the character of being a tyrant or a profligate, yet, if he be rich, he differs from all others; if he

${ }^{20}$ Newman, "Saintliness," 90.

${ }^{21}$ Ibid., 88.

${ }^{22}$ Ibid., 88-89. 
be rich, he has a gift, a spell, an omnipotence;-that with wealth he may do all things. ${ }^{23}$

Certainly the propensity to be lured into the pursuit of wealth, despite the many clear admonitions against it in the New Testament, did not originate in nineteenth-century Britain.Abundant evidence of the same can be found among the seventeenth-century Golden-Age Dutch, Renaissance elites, and indeed those wealthy medieval popes before, during, and after the Avignon papacy that, as the great twentieth-century economic historian R. H. Tawney said, "preached renunciation and gave a lesson in greed." ${ }^{24}$ Newman at once comments on a specific moment in a long historical process and criticizes a temptation that transcends any particular era. Industrialization was transforming this process in the nineteenth century, extending to a much broader social base the acquisitiveness that animated what Jan de Vries has called "the industrious revolution." ${ }^{25}$ Wedded to the pursuit of wealth, industrialization also made it possible to amass astonishing fortunes in the nineteenth century.

Newman's remarks about wealth are clearly applicable to contemporary America. Before turning to that point, however, it is worth mentioning briefly the other widespread idol he considers in the same address. Newman calls it "notoriety," and in contrast to the idolatrous fixation on wealth, he regards it as distinctive of his own time because of technological advances in transportation and communication:

Never could notoriety exist as it does now, in any former age of the world; now that the news of the hour from all parts of the world, private news as well as public, is brought day by day to every individual, as I may say, of the community, to the poorest artisan and the most deluded peasant, by processes so uniform, so unvarying, so spontaneous, that they almost bear the semblance of a natural law. ${ }^{26}$ Notoriety, "or the making a noise in the world," or, "as it may be called, newspaper fame," is like wealth "worshipped for its own sake, and without reference to the shape in which it comes before them. It may be an evil fame or a good fame; . . It matters not; so that a man is talked much of, and read much of, he is thought much of." ${ }^{27}$ What is noteworthy in the case of both wealth and notoriety, as Newman describes them, is the extent to which they have become ends in themselves; to which they have become the object of devotion for so many; and to which they are disconnected from moral concerns. The objective of wealth is its power and aura regardless of the use to which it is put or the moral character of the owner; similarly, the point of notoriety is to be noticed and noted, to be famous and regarded, regardless of the cause for attention. Oscar Wilde understood this, too: "[T]here is only one thing in the world worse than being talked about, and that is not being talked about." ${ }^{28}$

\footnotetext{
${ }^{23}$ Ibid., 89-90.

${ }^{24}$ R.H.Tawney, Religion and the Rise of Capitalism, rev. ed., with an introduction by Adam B. Seligman (1926; repr., New Brunswick, NJ, and London:Transaction, 1998), 62. On this long-term process by which, beginning with the medieval commercial revolution and monetization of the economy, Western Christianity unintentionally precipitated a capitalist and consumerist society antithetical to the condemnation of avarice as a deadly sin, see Brad S. Gregory, The Unintended Reformation: How a Religious Revolution Secularized Society (Cambridge, MA, and London: Belknap, 2012), 235-97. Hereafter cited: Gregory, Unintended Reformation.

${ }^{25}$ Jan de Vries, The Industrious Revolution: Consumer Bebavior and the Housebold Economy, 1650 to the Present (Cambridge: Cambridge University Press, 2008).

${ }^{26}$ Newman, "Saintliness," 90.

${ }^{27}$ Ibid., 90-91.

${ }^{28}$ Oscar Wilde, The Picture of Dorian Gray (Leipzig: Bernhard Tauchnitz, 1908), 9.
} 
The applicability of Newman's remarks to our own time again seems so selfevident as to warrant little comment. Indeed, if anything, his words seem rather quaint by comparison with the world of networked, instantaneous communication via the internet and the several trillions of dollars that change hands every day in the pursuit of more wealth in the extraordinarily complex-and fragile-world of global financial markets. Mere "newspaper fame" has been superseded by several orders of magnitude in comparison with websites and news stories receiving millions of hits from online users via laptops and smartphones all around the world. No one knows which YouTube video will be the next to "go viral"; it matters little if it disappears as quickly as it appeared, since another one, equally random and inconsequential, will arrive in its stead. Contemporary manifestations of notoriety also include forms of manufactured celebrity as seen in spectacularly mislabeled "reality TV" programs; both media genres make the proverbial fifteen minutes of fame about which Andy Warhol quipped seem long-lived. These examples are merely technologically facilitated extensions of the notoriety Newman identified as a pervasive idol in mid-nineteenthcentury England.

Today's deeply rooted, all-encompassing pursuit of wealth, which in turn facilitates what James Twitchell has called "our amoral consumerama," renders Newman's assessment of wealth as an idol rather tame by comparison. ${ }^{29}$ But it reinforces an appreciation for his prescience. In the United States today, the fact that the poorest households spend nine percent of their income on lottery tickets ${ }^{30}$ suggests the extent to which those of meager means do aspire to become wealthy; they are by no means content to admire the "lifestyles of the rich and famous" from a distance. ${ }^{31}$ As much as they can, they desire to become like the tiny, plutocratic proportion of the American population-less than one percent-that owns more than forty percent of the national wealth. ${ }^{32}$ We are dealing here, as Newman saw, with expressions of the autonomous, sovereign self, multiplied many millions of times over, expressing acquisitive desires and preferences in ways that are both more widespread and more deeply entrenched than they were a century and a half ago. So too, prophetic voices now are just as easily disregarded as his was then. The recent Occupy Movement, which raised objections to American socioeconomic realities and the moral injustices that sustain them and are produced by them-including their effects on millions of poor laborers in other countries-disappeared as quickly as it appeared. Pope Francis, however, seems unwilling to let this particular idolatry

\footnotetext{
${ }^{29}$ James Twitchell, "Two Cheers for Materialism," in The Consumer Society Reader, ed. Juliet B. Schor and Douglas B. Holt (New York: New Press, 2000), 281-90, 282. For a more extensive treatment, see also Twitchell, Lead Us into Temptation: The Triumph of American Materialism (New York: Columbia University Press, 1999), and Living It Up:America's Love Affair with Luxury (New York: Simon \& Schuster, 2002).

${ }^{30}$ Derek Thompson, "Amazing:The Poorest Households Spend 9\% of Their Income on Lottery Tickets," The Atlantic, 31 March 2012, bttp://www.theatlantic.com/business/archive/2012/03/amazing-the-poorestbousebolds-spend-9-of-their-income-on-lottery-tickets/255304/.

${ }^{31}$ Lifestyles of the Rich and Famous was a popular TV show, hosted by Robin Leach, that aired in syndication between 1984 and 1995. Internet Movie Database, Lifestyles of the Rich and Famous, bttp://www.imdb.com/title/tt0086750/.

${ }^{32}$ See, for example, Chrystia Freeland, Plutocrats: The Rise of the New Global Super-Rich and the Fall of Everyone Else (New York: Penguin, 2012).
} 
alone..$^{33}$

So one manifestation of the sovereign self is the commitment to a nontranscendent horizon for self-determined pursuits and pleasures, whatever they might be; a second is the extent to which human beings are enmeshed in the pursuit of wealth and live in societies obsessed with notoriety and celebrity. A third expression of the autonomous self on which Newman comments with perspicacity is the arbitrariness of beliefs and truth claims in the absence of Catholicism. The passage in question is drawn from near the end of "Mysteries of Nature and of Grace." Newman begins with a provocative assertion:"[T] urn away from the Catholic Church, and to whom will you go? it is your only chance of peace and assurance in this turbulent, changing world." ${ }^{34}$ Newman continues:

There is nothing between [the Catholic Church] and scepticism, when men exert their reason freely. Private creeds, fancy religions, may be showy and imposing to the many in their day; national religions may lie huge and lifeless, and cumber the ground for centuries, and distract the attention or confuse the judgment of the learned; but on the long run it will be found that either the Catholic Religion is verily and indeed the coming in of the unseen world into this, or that there is nothing positive, nothing dogmatic, nothing real, in any of our notions as to whence we come and whither we are going. Unlearn Catholicism, and you open the way to your becoming Protestant, Unitarian, Deist, Pantheist, Sceptic, in a dreadful, but inevitable succession; only not inevitable by some accident of your position, of your education, and of your cast of mind; only not inevitable, if you dismiss the subject of religion from your view, deny yourself your reason, devote your thoughts to moral duties, or dissipate them in engagements of the world. ${ }^{35}$ This has proven prophetically suggestive of the basic trajectory of Western society since the Protestant Reformation. Let us allow for the idiosyncratic, individual differences to which Newman rightly alludes and compare this passage to the history of what Western men and women have claimed is true in matters of religion, morality, and values since the early sixteenth century. This trajectory is not a process of one stage superseding another, through which Western society as a whole passed between then and the mid-nineteenth (or early twenty-first) century, but rather allows us to account for every Christian or post-Christian claim made about belief, values, and priorities between the 1520 s and the present. At no point in England since the Reformation, or in Germany, France, the Low Countries, or in England's North American colonies that became the United States, has there been a shared Christian or post-Christian view about what people should believe or how they should live. That is because-as Newman saw so clearly-the corrosive criticism generated by skeptical rationalism of faith claims that are merely preferential is bound

${ }^{33}$ In addition to many other such comments since Jorge Mario Bergoglio's election to the Holy See in March 2013, see Pope Francis, The Joy of the Gospel: Evangelii Gaudium (Washington, D.C.: United States Conference of Catholic Bishops, 2013), Chapters 2 and 4.

${ }^{34}$ Newman, "Mysteries of Nature and of Grace," in Discourses, 282. This is perhaps too baldly put if regarded in a broader context, insofar as it does not consider that other religious traditions, such as Judaism or Islam, seem indeed to provide just such peace and assurance to many of their respective members. Prima facie, one of them might be true; but that was not Newman's context, and his remarks were meant to apply in a context of post-Reformation Western Christianity and, increasingly, post-Christian, postEnlightenment Western secularism.

${ }^{35}$ Ibid., 282. 
to expose that arbitrariness, and lead one on, as it were, to another preferential and therefore no more stable position, until the same process works itself out and ends in some form of skepticism itself.Yet the concrete, circumstantial particularities relevant in any given individual's situation-the fact that someone was brought up in a particular Protestant church in which strong social ties and moral values were instilled, for example, or the fact that someone else simply likes the non-dogmatic, emotionally soothing experiences that might accompany some forms of Romanticcum-New-Age pantheism-enable us to account for the fact that not everyone has become a post-Christian, rationalist skeptic. Newman's point is that there is no good reason not to be a skeptic, once one has cast off the deference to authority and imperative of obedience at the heart of what substantive definitiveness in God's selfrevelation implies. If there is no specifiable divine revelation and no authority outside oneself, one becomes one's own authority and believes whatever one pleases-as an expression of modernity's sovereign self. One ends with nothing but pragmatic assertions based on preferences and implicit but ultimately arbitrary claims about one's own view of the good.

Newman, of course, did not live to see modernity become postmodernity-but this passage has proven prophetic if we think of it not only with respect to secularization, but also the collapse of philosophical foundationalism in recent decades. What Newman perceived with respect to the application of skeptical reason to competing views of Christian and post-Christian religion also applies to the attempts from Descartes onward to answer on the basis of reason alone the questions about morality, meaning, and metaphysics that have been and still are answered by religious traditions, including Christianity. The Reformation's emphasis on Scripture alone failed to provide a shared basis for consensual answers to these kinds of life questions without reference to authority or tradition, and now it is widely recognized that the Enlightenment's confidence in "reason alone" has similarly failed in the same objective. This failure of modern philosophical foundationalism has meant, in effect, a return of skepticism in postmodern forms after a modern philosophical detour of more than three centuries. ${ }^{36}$ It has even meant a renewed turn toward religion in the German philosopher Jürgen Habermas, who in his early career was resolutely secular but who, especially since 2001 , seems to recognize the increasingly apparent weakness of modern liberalism, whether in its Kantian or Lockean lineages, in trying to justify the reality of categories central to its own discourse: "human rights," "persons," and "human dignity," for example. ${ }^{37}$ Newman intuited the problem that secular liberal theorists ${ }^{38}$ now face: that of trying to justify why we should believe that "rights" are any more real than "souls" while the natural sciences demonstrate their cumulatively impressive power to explain reality at every level without recourse

\footnotetext{
${ }^{36}$ Gregory, Unintended Reformation, 112-26.

${ }^{37}$ I have made this argument in a recent unpublished essay. Brad S. Gregory, "Habermas's Postsecularism as Symptom: Religion and Democracy, History and Metaphysics in the Age of Fracture," paper presented at the conference "Theorizing Religion in Modern Europe," Harvard University, 8 March 2014. The same argument is made more generally, without specific reference to Habermas, in Gregory, Unintended Reformation, 224-29 and 380-81. For more on Habermas, see also Eric John Bugyis, "Postmetaphysical Madness: A Critique of the Postsecular Return of Religion in the Thought of Jürgen Habermas," PhD diss., Yale University, 2013. For a variety of perspectives on Habermas's "postsecularist turn," see the contributions in Craig Calhoun, Eduardo Mendieta, and Jonathan VanAntwerpen, eds., Habermas and Religion (Cambridge, U.K., and Malden, MA: Polity, 2013).
} 
either to souls or rights-the ongoing triumph of Occam's razor.

Essentially, Newman's argument in this passage implies that either one embraces Catholicism, including the dogmas and authority correlative to the claims that Roman Catholicism preserves and develops as the understanding of God's self-revelation to humanity; or, through the consistent exercise of one's critical and skeptical reason without restrictions, one will be forced to confront and adopt Nietzsche's bald assertion in Twilight of the Idols: "There are no moral facts whatsoever." ${ }^{9}$ Fortunately, most of those who reject Catholicism are not prepared to accept this, and instead make inconsistent assertions about rights, dignity, and morality. But as Newman foresaw, this is simply because of "some accident of [their] position, ... education, and. . . cast of mind." Today's society is saturated with a soft Nietzscheanism, a moral culture that insists adamantly on human rights with multiple rival claims about what they are and what they should be, including the right of individuals to answer for themselves, to the greatest extent permissible, all questions about what is good, right, and true. In 1992, the U.S. Supreme Court made this quite plain in its majority decision in Planned Parentbood v. Casey: "At the heart of liberty is the right to define one's own concept of existence, of meaning, of the universe, and of the mystery of human life." 40 Here we see the explicit recognition and legal protection of the autonomous, sovereign self that exercises its preferences, whatever they might be, with respect to matters of meaning, metaphysics, and morality. In short, Newman mapped out in 1849 what I refer to in The Unintended Reformation as "the Kingdom of Whatever." ${ }^{11}$ It is the present-day sociocultural expression of the political liberalism that had begun to develop in Newman's era.

Finally, let us move from these passages about the modern sovereign self in the Discourses to that self and higher education in Newman's Idea of a University, the lectures for which were originally delivered in Dublin in 1852. This portion of the present essay is indebted to an excellent recent article by Reinhard Hütter,"University Education, the Unity of Knowledge - and (Natural) Theology: John Henry Newman's Provocative Vision." ${ }^{42}$ The manifestations of the sovereign self's will are somewhat less apparent in The Idea of a University than in Discourses. Yet Newman's thought in this volume is, in a sense, all the more remarkably prophetic insofar as he neither envisioned the Catholic University of Dublin as a research university in 1852; nor did a research university yet exist in England, whether at Oxford, Cambridge, or the new universities in Durham (established in 1832) or London (1836), at the time. Oxford and Cambridge did not deconfessionalize or begin to adapt the model of the German research university until the 1870s. In the same decade across the Atlantic, the same German model was differently adapted with the creation of the "Graduate School" at

\footnotetext{
${ }^{38}$ For several recent examples of liberal political theorists who seek to justify the reality and importance of human rights and human dignity, see Ronald Dworkin,Justice for Hedgebogs (Cambridge, MA: Belknap, 2011); George Kateb, Human Dignity (Cambridge, MA: Harvard University Press, 2011); and Jeremy Waldron, Dignity, Rank, and Rights, edited and with an introduction by Meir Dan-Cohen (New York: Oxford University Press, 2012).

${ }^{39}$ Friedrich Nietzsche, Götzen-Dämmerung, 92.

${ }^{40}$ Planned Parenthood v. Casey, 505 U.S. 833 (1992) \$2.

${ }^{41}$ Gregory, Unintended Reformation, 112.

${ }^{42}$ Reinhard Hütter, "University Education, the Unity of Knowledge-and (Natural) Theology: John Henry Newman's Provocative Vision," Nova et Vetera 11, no. 4 (2013): 1017-056. Hereafter cited: Hütter, "University Education."
} 
American universities such as Johns Hopkins and Harvard ${ }^{43}$ This makes all the more noteworthy Newman's remarks about individual preference in relationship to scientific accounts of human beliefs and actions, when these accounts ignore theology. It is as though Newman foresaw what the impact of these guiding principles would eventually be on an institution with which he was not familiar and that in Britain and Ireland did not even exist at the time he made his remarks.

In the second discourse of his Idea of a University, Newman refers to "a state of society such as ours, in which authority, prescription, tradition, habit, moral instinct, and the divine influence go for nothing, in which patience of thought, and depth and consistency of view, are scorned as subtle and scholastic, in which free discussion and fallible judgment are prized as the birthright of the individual[.]" ${ }^{44}$ This coheres with his description of a society of autonomous individuals living for themselves according to their own preferences in Discourses. It seems especially applicable to American higher education today; we are in the midst of a technologically facilitated transition in curriculum from a previous emphasis on the careful reading of complex texts and the comprehension of demanding ideas to an emphasis on the ability to access large amounts of information and on the quantitative analysis of big data for practical deliverables with quantifiable outcomes. ${ }^{45}$ The humanities are marginalized and increasingly imperiled, whereas the STEM (Science, Technology, Engineering, and Mathematics) disciplines increasingly dominate. According to Newman, this kind of higher education results in the expression of antagonistic claims that arouse "the extreme sensitiveness of large classes of the community, clergy and laymen, on the subjects of necessity, responsibility, the standard of morals, and the nature of virtue." 46 Because technical education lacks the resources to address the resulting conflicts,

the only way of avoiding constant quarreling in defence of this or that side of the question is, in the judgment of the persons I am supposing, to shut up the subject of anthropology altogether. This is accordingly done. Henceforth man is to be as if he were not, in the general course of Education; the moral and mental sciences are to have no professorial chairs, and the treatment of them is to be simply left as a matter of private judgment, which each individual may carry out as he will. ${ }^{47}$ In other words, the kinds of questions that seem manifestly beyond resolution in academic discourse are instead left to individual discretion while universities pretend to be morally neutral institutions. In the words of the political scientist John Mearsheimer,

\footnotetext{
${ }^{43}$ See A. J. Engel, From Clergyman to Don: The Rise of the Academic Profession in Nineteenth-Century Oxford (Oxford: Clarendon, 1983), 77-81 and 173-78; see also James Turner and Paul Bernard, "The 'German Model' and the Graduate School:The University of Michigan and the Origin Myth of the American University," in Turner, Language, Religion, Knowledge: Past and Present (Notre Dame, IN: University of Notre Dame Press, 2003), 69-94.

${ }^{44}$ Newman, The Idea of a University, ed. Frank M. Turner (New Haven, CT: Yale University Press, 1996), 2.7, 36. Hereafter cited: Newman, Idea of a University.

${ }^{45}$ For consideration of this complex, widespread process from a variety of perspectives, see, for example, Jennifer Washburn, University, Inc.: The Corporate Corruption of Higher Education (New York: Basic Books, 2005); Gaye Tuchman, Wannabe U:Inside the Corporate University (Chicago: University of Chicago Press, 2009); Richard Alum and Josipa Roksa, Academically Adrift: Limited Learning on College Campuses (Chicago: University of Chicago Press, 2010); Andrew Delbanco, College: What it Was, Is, and Should Be (Princeton: Princeton University Press, 2012); and William G. Bowen, Higher Education in the Digital Age (Princeton: Princeton University Press, 2013).

${ }^{46}$ Newman, Idea of a University 3.5, 47.

47 Ibid., 47
} 
Universities do not have a moral agenda and do not give students moral guidance, because that would involve preaching about values, and that is an enterprise that holds hardly any attraction for modern universities. Religious institutions and families are expected to provide their members with explicit advice about moral virtue, but universities are not. ${ }^{48}$

What actually happens, however, is a combination of alleged institutional moral neutrality combined with the importation of scholars' arbitrary moral preferences, as an expression in higher education of the principles governing the sovereign self's preferences in the wider society. ${ }^{49}$

As Newman sees it, the individually determined preferences of the sovereign self replace any socially shared views about what is true, right, and good as part of a common religious tradition. In the university setting, both the endless disagreements among practitioners of the human sciences and the disintegration of the relationships between academic disciplines are corollaries of the rejection of theology as an intellectually integrative endeavor. ${ }^{50}$ In Newman's words, "You will soon break up into fragments the whole circle of secular knowledge, if you begin the mutilation with divine." ${ }^{51}$ This was an acute prognostication about the ubiquitous specialization and disciplinary fragmentation characteristic of research universities since the late nineteenth century, which has never been more apparent than today. One of its symptoms is the widespread call for more interdisciplinary, transdisciplinary, and multidisciplinary academic work, which nevertheless remains unmotivated by any concern for the integration of knowledge within a commitment to the unitary character of truth. Newman would almost certainly have agreed with Alasdair MacIntyre's argument that we really ought not to speak of "universities" any longer, because in no meaningful sense do they offer or seek to offer any coherent picture of the universe; he would likely also have approved of the term "multiversity," coined by Clark Kerr over fifty years ago, as being more accurately descriptive of universities today. Indeed, he would have understood well Reinhard Hütter's critical epithet, "polytechnic utiliversity," as the term best suited to replace the obsolete misnomer, "university." The universities, having banished any discipline that is conceptually capable of relating different fields of knowledge to one another, and having marginalized the humanities and social sciences because of their importation of arbitrary preferences from the wider society, allow the natural sciences to move into the space vacated by these fields and theology and to replace the integration of knowledge with reductionist explanation. In the early 1850s, this was largely a matter of Newtonian mechanistic causality, with "[h]uman exploits, human devices, human deeds, human productions" all explained with reference to "their place in the eternal

\footnotetext{
${ }^{48}$ John J. Mearsheimer, "Mearsheimer's Response: 'Teaching Morality at the Margins," Pbilosophy and Literature 22 (1998): 195.

${ }^{49}$ It is academic sociologists' unwillingness to acknowledge this covert, Durkheimian sacred and indeed spiritual agenda about the maximization of individual preferences, cloaked in the guise of neutral analysis and the "science of society," that Smith criticizes in American sociology. Smith, Sacred Project.

${ }^{50}$ For consideration of this process as a long-term phenomenon with its roots in the Reformation era, see Gregory, Unintended Reformation, especially Chapter 6.

${ }^{51}$ Newman, Idea of a University 2.3, 29.

${ }_{52}$ Alasdair MacIntyre, God, Philosophy, Universities: A Selective History of the Catbolic Philosophical Tradition (Lanham, MD: Rowman \& Littlefield, 2009), 15-18 and 174-176; Clark Kerr, The Uses of the University, 5th ed. (Cambridge: Harvard University Press, 2001), 5; Hütter, "University Education," 1023.
} 
system of physical cause and effect," the final aim being "to show how the whole fabric of material civilization has arisen from the constructive powers of physical elements and physical laws." ${ }_{33}$ Today the dominant reductionism comes not from physics but from biology in the form of neo-Darwinism, with evolutionary theory extolled in disciplines from neuroscientific psychology to social anthropology and, increasingly, even the humanities as the key to the explanation of everything about human culture, social relationships, beliefs, desires, and behavior.

Yet the modern natural sciences are not only about discovery and understanding; they are also about utility and application. This understanding can be used for whatever purpose human beings-or more accurately, those human beings with the requisite knowledge, means, and power-decide to use it. Here the individual autonomy of the sovereign self is already beginning to meet the technical capability of human eugenics in ways that Newman could not have foreseen-and by which he would certainly have been appalled, if not, perhaps, surprised. ${ }^{54}$ He grasped what a university might become without theology as its integrative discipline, saw the combination of seeming value-neutrality with its arbitrariness with regard to human morality, and was concerned about the imperialistic reductionism of the natural sciences, even if no one in the nineteenth century could have foreseen the specific biotechnological possibilities with which we are now confronted.

Despite all that has changed since the mid-nineteenth century, what hasn't changed are the dominant conceptions of and commitments to the sovereign individual self and the maximization of its choices, the facilitation of its preferential pursuits, and the fulfillment of its desires as the cornerstone of what Western modernity is and what Western postmodernity remains. Newman saw this in the 1840s; it remains no less true now; and that is why, as a social observer and cultural critic, he should be regarded as prophetic. Correlatively, that is why his writings remain so powerfully relevant today, and why they will likely continue to inspire readers in the future. He thought he was living in threatening, difficult times. But just as Newman sought to use his reason as a handmaiden to hope in criticizing those aspects of modernity he regarded as dangerously misguided, so for our own times we should seek to do likewise.

\footnotetext{
${ }^{53}$ Newman, Idea of a University, 3.5, 49.

54 "The proponents of a liberal eugenics are naive enough to assume that the ensuing combination of biotechnological and socio-political dynamics can be 'managed' by the benign intentions of enlightened individuals and an equally benign and enlightened political process in equally benign and enlightened democratic regimes." Hütter, "University Education,” 1040.
} 


\section{BOOK REVIEW}

John Henry Newman: Spiritual Director (1845-1890). By Peter C.Wilcox, S.T.D., Eugene, Oregon: Pickwick Publications, 2013. Pages: 362. Softcover, \$33.60. ISBN: 9781620322048.

Peter C. Wilcox's John Henry Newman: Spiritual Director (1845-1890), achieves a feat both unique and fruitful: through its attentiveness to a particular aspect of Newman's life, the book casts light on the whole of his mission and work. Wilcox focuses on Newman's letters, which he shows are a treasure trove of insights on spiritual direction. Wilcox grants that while Newman did not embrace the title of spiritual director, his letters to many people during his Catholic period (1845-1890) demonstrate that he performed that role with rare aplomb and earnestness. In this sense, Wilcox's book does for Newman what Wendy M. Wright and Joseph F. Power did for Francis de Sales in their ground-breaking Classics of Western Spirituality volume, Francis de Sales, Jane de Chantal: Letters of Spiritual Direction (1988): illuminate the deeper coherence of a theologian's ideas by examining the practical advice he or she gives to others about how to pray and discern God's role in one's life.Wilcox's book takes seriously Newman's own words to his sister Jemima in 1863: "[A] man's life lies in his letters." With Newman's own maxim as his guide, Wilcox is a masterful study of the underlying logic of Newman's theological mind.

There are two interwoven theses in Wilcox's book. The first is that we learn some fundamental truths about Newman's own spirituality by examining the advice he gave to others. The second is that these fundamental truths help us see Newman's remarkable blending of theological reflection and the concerns of practical, everyday life.Together, they present a picture of Newman as a man whose scholarly interest in the Christian past, particularly the writings of the Greek Church Fathers and the doctrinal tradition closely associated with them, was in a close symbiosis with his own sense of vocation and mission in the present.

Wilcox notes in his introduction that Newman recognized an important distinction between his published scholarly works and his letters. Whereas his books would be read with close and often malevolent scrutiny, therefore requiring vigilant caution with regard to what he put on the page, in his letters Newman could afford to be more candid and unguarded $;^{2}$ they show a side of Newman not on display elsewhere. Yet there is more to this distinction. In the letters Newman corresponds with a wide variety of people, not all of them scholars. The copious letters he wrote tell a story about Newman that deepens what we know about him, and that indeed can function as a hermeneutic lens through which to view his private mind. If Newman's Apologia is the first sustained effort at interpreting his own life, then his letters must also count as an indispensable part of this self-interpretation project. As

\footnotetext{
${ }^{1}$ Newman to Jemima Newman, 18 May 1863, in Letters and Diaries of John Henry Newman, vol. 20, ed. Charles Stephen Dessain (London:Thomas Nelson and Sons, 1970), 443.

${ }^{2}$ Wilcox, introduction to John Henry Newman: Spiritual Director (1845-1890) (Eugene, OR: Wipf and Stock, 2013), xv-xxii, xix. Hereafter cited:Wilcox, "Introduction."The larger text is hereafter cited:Wilcox, John Henry Newman.
} 
Wilcox notes, Newman always maintained that it is the whole person who thinks, not just the intellect. ${ }^{3}$ In his many letters offering advice on prayer and spiritual discernment, Newman demonstrates what he means by his more abstract statements on this point. For example, after reading Wilcox's book, I will not read An Essay in Aid of a Grammar of Assent the same way as I had before.

One conclusion that Wilcox draws from reading Newman's letters is that the laity and the unique processes they undergo on their own paths to holiness-or nonholiness, as the case may be-were truly central to Newman's thinking about the Church and his mission in it. That may seem like a trivial conclusion to those accustomed to thinking of Newman as a precursor to Vatican II's "universal call to holiness." ${ }^{4}$ Yet what Wilcox shows is that Newman was not simply a precursor or champion of an abstract theory about the importance of lay holiness: he was as deeply engaged in the concrete realities of lay Christian faith as one could possibly be, and far more than most theologians of his time, or ours. Newman did not simply advocate a theory of a unified theology and spirituality: he engaged in detailed, sustained (and sometimes messy and confusing) human friendships to facilitate holiness in the vicissitudes of daily life. Wilcox's book demonstrates that Newman took the most serious responsibility possible for his religious ideas through his close, loving bonds with numerous people who sought his guidance. Newman did not "play" at theology, nor did he use theological discourse to advance his academic career. Wilcox's book makes clear how profoundly earnest and vivaciously real Newman was when he put pen to paper to offer words about God and His ways.

Another valuable conclusion that Wilcox draws is that Newman's mind was welldisciplined in intellectual humility. Again, this is not a surprising conclusion (at least not for those skeptical of Frank M. Turner's portrayal of Newman). ${ }^{5}$ Nevertheless, Wilcox makes it abundantly clear that for Newman, developing ideas about God and the Church was not a process of self-aggrandizement or self-promotion. Rather, Newman's ideas about God and Church were the fruit of his reflections on his own experience, the experiences of those with whom he wrote, and the dialogues that resulted when these two sets of experiences came together in his correspondence. The fact that Newman's spiritual advice and guidance did not follow a specific method or practice a fixed technique, as Wilcox explains, illustrates that he had a profound grasp of the inscrutability of God's providence and his own limits in understanding it. This is why Newman's personality is so clearly revealed in the letters: he was simply there for others, a loving presence to accompany them on their journeys. Wilcox observes that Newman had a gift for rhetoric, used not to dazzle others with his intellectual prowess, but to make others "feel accepted, important, and unique." ${ }^{\prime}$ The point of his letters was to exercise his personal influence, not to lecture; in turn, this influence was about modeling attitudes that would give courage,

\footnotetext{
${ }^{3}$ Wilcox, "Introduction," xxi.

${ }^{4}$ Pope Paul VI, "Universal Call to Holiness in the Church," 21 November 1964, in Lumen Gentium, Ch. 5 , bttp://www.vatican.va/archive/hist_councils/ii_vatican_council/documents/vat-ii_const_19641121_ lumen-gentium_en.btml.

${ }_{5}^{5}$ Turner, John Henry Newman: The Challenge to Evangelical Religion (Newhaven, CT: Yale University Press, 2002).

${ }^{6}$ Wilcox, John Henry Newman, 335.
} 
support, and constancy to those with whom he wrote. Wilcox sums up Newman's approach when he writes in his conclusion:

Newman also had the kind of personality that could challenge people while still allowing them to be free. Without being overbearing, his desire was "to speak the truth in love," to be honest with people even at the risk of personal sacrifice; yet, when he realized he had been insensitive or wrong, he did not hesitate to apologize.... [H] is correspondence shows that Newman was extremely sensitive to others. People constantly wrote to him about almost every facet of life, presumably because they believed he would understand. ${ }^{7}$

This ability to be empathetic and win deep personal trust is rare among the extremely learned, frankly. To "understand" for many scholars means to understand complex books and abstract ideas, not people. That was not that case for Newman. Wilcox presents a convincing picture of Newman as a man who understood complex books and abstract ideas not for their own sake, but for the sake of the questing, troubled, and anxious children of Eve who came to him for counsel. This is certainly a welcome book in the field of Newman studies, and I strongly recommend it to all who want to better understand Newman as a man and intellectual. But it is also a welcome book for scholars of religion and professors of the humanities. It is a book for all who care about religious and humanistic ideas, but it is also a book for those who simply care about real people in their daily struggles with faith and doubt, love and hate, hope and despair. Wilcox's study can and should transcend disciplinary boundaries.

Kevin Mongrain Duquesne University and NINS, Pittsburgh, PA 


\section{WHAT'S NEW AT NINS MARY JO DORSEY}

NINS is pleased to announce that it will launch a redesigned website early in 2015.

The new redesigned website has been in development for the past year. Our main goal was to build a user-friendly, simple-to-navigate site. The new design complements the interface style of our new digital archive. The new site features a YouTube ${ }^{\circledR}$ video channel that features informative videos about our projects. Also to appear are video recordings of lectures and other Newman-related activities. The new website URL is www.newmanstudies.org.

As we continue to develop our web presence, watch for the launching of our Facebook ${ }^{\circledR}$ and LinkedIn ${ }^{\circledR}$ pages, as well as a NINS Twitter ${ }^{\circledR}$ feed.

\section{The Newman archive digitization project continues.}

As mentioned in the previous issue of NSJ, NINS's exciting work of digitizing the contents of Cardinal Newman's archive, housed at the Birmingham Oratory in England, moves forward.

In October 2014, we anticipate having close to 100,000 digitized images as a result of the Newman Archive Digitization project.

Along with the letters, diaries, and manuscripts, recently digitized items include a framed drawing by a young Newman depicting himself and his schoolmates in conversation, as well as a framed handwritten statement by St. Philip Neri from 1584.

\section{Third Annual Newman Memorial Lecture}

This year's Newman Memorial lecture, delivered by Dr. Peter Wilcox at Duquesne University, is titled "Newman as Spiritual Director: His Personal Methods and Their Meaning for Understanding His Life". It took place on Wednesday, October 15, 2014 at 5:00pm at Duquesne University's Duquesne Union Ballroom.

Dr. Wilcox explores the counseling dimension of Newman's life during the Catholic years, 1845-1890. He examines the major areas in which Newman offered spiritual direction and uncovers the methods he used and the reasons why so many were attracted to him as a guide in the spiritual life. 


\section{NEWMAN BIBLIOGRAPHY AND GENERAL RESOURCES}

The Newman Reader (www.newmanreaderorg) provides complete texts of the "uniform edition" of most of Newman's published writings, along with biographies and pictures of Newman. Specific terms or phrases from Newman's writings can be found by visiting the Google website and entering: «word/phrase» site: newmanreader.org. For scholarly research, the National Institute for Newman Studies, in partnership with Crivella West, Inc., has established the Newman Knowledge Kiosk, which provides indexing tools to search for specific terms in Newman's writings. To request access to the Kiosk, visit: bttp://www.newmanstudiesinstitute.org.

A Newman bibliography from 1990 to the present is available on the website of the International Centre of Newman Friends (www.newmanfriendsinternational.org). Authors of articles on Newman that appear in other journals are asked to inform the Centre of their publications by email: centro.newman@tiscali.it. "Project Canterbury" (bttp://anglicanbistory.org/index.html) provides information about the Oxford Movement, including a "timeline of the Oxford Movement"; another useful resource for nineteenth-century Anglicanism is www.anglicanbistory.org.

\section{Recent Research}

Authors of articles on Newman that appear in other periodicals are requested to email an electronic copy of their publications to the Newman Studies Journal (kmongrain@ninsdu.org) for inclusion in its electronic library; writers of theses and dissertations are invited to submit a summary of their research to the Newman Studies Journal. Synopses of selected articles and research projects appear as a regular feature of this journal.

\section{Recent Publications on Cardinal Newman (2014)}

Arthur, James, and Guy Nicholls.Jobn Henry Newman. Bloomsbury Library of Educational Thought (New York: Bloomsbury, 2014).

Drennen, D.A. A Privilege of Intellect: Conscience and Wisdom in Newman's Narrative. Scranton: University of Scranton Press, 2014.

Gliebe, Joseph Julius. Cardinal Newman's Dream of Gerontius: With Introduction and Commentary, for Use in High Schools, Academies and Colleges. (Whitefish, MT: Literary Licensing, 2014).

Ker, Ian. Newman on Vatican II. (Oxford: Oxford University Press, 2014).

Kuczoc, Marcin. The Conceptualisation of the Christian Life in Jobn Henry Newman's Parochial and Plain Sermons. (Newcastle upon Tyne, UK: Cambridge Scholars, 2014). 
Myers, William F. The Thoughtful Heart:The Metaphysics of Jobn Henry Newman. With A Fully Annotated Readers'Text of Newman's Discursive Enquiries on Metaphysical Subjects. Marquette Studies in Philosophy. Milwaukee, WI: Marquette University Press 2014.

Poston, Lawrence. The Antagonist Principle:Jobn Henry Newman and the Paradox of Personality. Victorian Literature and Culture Series. (Charlottesville, VA: University of Virginia Press, 2014).

Strong, Rowan, and Carol Engelhardt Herringer, eds. Edward Bouverie Pusey and the Oxford Movement.Anthem Nineteenth-Century Series. (New York:Anthem, 2014). 


\section{JOHN HENRY NEWMAN}

\section{A Brief Chronology}

\begin{tabular}{|c|c|c|}
\hline 1801 & February 21 & Born, Old Broad Street, London; Baptized:April 9. \\
\hline 1808 & May 1 & Enrolled at Ealing School \\
\hline \multirow[t]{2}{*}{1816} & August-December & First conversion \\
\hline & December 14 & Enrolled at Trinity College, Oxford \\
\hline 1820 & December 5 & Took B.A. degree "under the line" \\
\hline 1822 & April 12 & Elected Fellow of Oriel College \\
\hline \multirow[t]{2}{*}{1824} & June 13 & Ordained deacon of the Church of England \\
\hline & July 4 & Began "duty" at St. Clement's, Oxford \\
\hline 1825 & May 29 & Ordained priest of the Church of England \\
\hline 1826 & July 2 & Preached first Oxford University sermon \\
\hline \multirow[t]{2}{*}{1828} & January 5 & "We lost my sister Mary suddenly" \\
\hline & March 14 & "Instituted by the Bishop of Oxford to St Mary's" \\
\hline 1831 & June-July 1832 & Writing: The Arians of the Fourth Century \\
\hline 1832 & December 8 & Beginning of Mediterranean voyage with the Froudes \\
\hline \multirow[t]{2}{*}{1833} & June 16 & "Lead Kindly Light" ("The Pillar of the Cloud") \\
\hline & July 14 & Keble's Assize sermon on "National Apostasy" \\
\hline 1839 & January, May & Preached Oxford University Sermons X, XI, XII \\
\hline 1840 & June 29 & Preached Oxford University Sermon XIII \\
\hline 1841 & January 25 & Published Tract XC \\
\hline 1843 & February 2 & Preached Oxford University Sermon XV \\
\hline 1843 & September 25 & Preached "The Parting of Friends" at Littlemore \\
\hline \multirow[t]{2}{*}{1845} & October 9 & Received as a Roman Catholic by Dominic Barberi \\
\hline & & An Essay on the Development of Christian Doctrine published \\
\hline 1847 & May 30 & Ordained a Roman Catholic priest in Rome \\
\hline 1848 & February 1 & Established the English Oratory \\
\hline 1851 & November 5 & Beginning of Achilli Trial \\
\hline \multirow[t]{2}{*}{1852} & May 10 & Delivered first university lecture in Dublin \\
\hline & July 13 & Preached "The Second Spring" \\
\hline 1853 & January 31 & Fined $£ 100$ at conclusion of Achilli Trial \\
\hline \multirow[t]{2}{*}{1854} & March 22 & Opening of the London Oratory at Brompton \\
\hline & June 4 & Installed as Rector of the Catholic University in Dublin \\
\hline 1856 & May 1 & Dedication of Catholic University Church of Sts. Peter and Paul \\
\hline 1857 & March & Informed Irish bishops of his proposed resignation as rector \\
\hline 1859 & July & "On Consulting the Faithful" published in The Rambler \\
\hline 1864 & April-June & Apologia pro Vita Sua published in fascicles \\
\hline 1865 & May-June & "The Dream of Gerontius" published in The Month \\
\hline 1870 & March 15 & An Essay in Aid of a Grammar of Assent published \\
\hline 1875 & January 14 & A Letter to the Duke of Norfolk published \\
\hline 1878 & February 26-28 & Visit to Oxford: Honorary Fellow of Trinity College \\
\hline 1879 & May 15 & Received the "red hat" from Pope Leo XIII in public consistory \\
\hline 1890 & August 11 & Newman's death; burial at Rednal on August 19 \\
\hline 1900 & October 3 & Premiere of Sir Edward Elgar's The Dream of Gerontius \\
\hline 1991 & January 22 & Declared "Venerable" by Pope John Paul II \\
\hline 2010 & September 19 & Beatified by Pope Benedict XVI \\
\hline
\end{tabular}

